AnUario de Estudios Medievales

40/1, enero-junio de 2010

pp. $129-179$

ISSN 0066-5061

\title{
GOVERNAR EL DEUTE EN TEMPS DE CRISI: CASTELLÓ D'EMPÚRIES (1386-1421)
}

\author{
GOVERNING PUBLIC DEBT IN TIMES OF CRISIS: \\ CASTELLÓ D'EMPÚRIES (1386-1421)
}

\author{
AlBert MARTí ARAU \\ Institució Milà i Fontanals \\ CSIC, Barcelona
}

\begin{abstract}
Resum: Des del final del s. XIV, molts consistoris catalans van haver de confeccionar memorials o "capbreus" de rendes que facilitessin l'administració de l'enorme deute contret anteriorment i clarifiquessin la situació jurídica de cada renda per evitar malentesos amb el seu propietari. El present article analitza dos capbreus de censals redactats entre 1410 i 1421 pels dirigents de Castelló d'Empúries, la capital d'una de les senyories més importants de Catalunya. A la llum d'aquests volums, es responen alguns dels interrogants que encara existeixen sobre les finances urbanes a la Catalunya baixmedieval: conèixer el nivell d'endeutament que assoliren els llocs de senyoriu; estudiar les polítiques financeres que endegaren els governs municipals per intentar disminuir el volum dels interessos anuals; i, finalment, copsar la procedència geogràfica i el perfil social dels creditors municipals.

Paraules clau: Deute municipal; Capbreus; Censals; Creditors; Castelló d'Empúries; s. XIV-XV.
\end{abstract}

\begin{abstract}
Since the end of the 14th century, many Catalan towns were asked to issue memorials of rents that, in the one hand, would facilitate the administration of the huge debt they had got into previously and, on the other hand, would clarify the juridical situation of each rent to avoid misunderstandings with its owner. This article aims at analyzing two memorials of rents written up between 1410 and 1421 by the local authorities of Castelló d'Empúries, the main city of one of the most important lordships of Catalonia. With the help of these volumes, we are trying to solve some of the questions about the urban finances in medieval Catalonia: what the level of indebtedness that the noble places attained; what financial policies the urban rulers put forward to reduce the volume of the annual interests; and, finally, what the geographical origin and the social profile of the municipal creditors was.

Key words: Municipal Debt; Memorials; Rents; Creditors; Castelló d'Empúries; 14 15 th centuries.
\end{abstract}

\section{SUMARI}

Introducció.- 1. Els capbreus de censals del s. XV.- 2. La crisi financera del municipi: 2.1. La suspensió de pagaments (1393-1410). 2.2. La reducció del deute (1410-1421). 2.3. El resultat de la política de reducció del deute (1421).- 3. Els creditors de Castelló d'Empúries: 3.1. La geografia del deute (1421). 3.2. El mercat secundari del deute. 3.3. El perfil social dels creditors (1421). 4. Consideracions finals. 


\section{INTRODUCCIÓ ${ }^{1}$}

D'ençà del pioner treball de Josep $\mathrm{M}^{\mathrm{a}}$ Font Rius aparegut ara fa més de 25 anys, l'estudi de les finances locals en l'àmbit del principat ha despertat l'interès de diversos historiadors i, mercès a llurs treballs, s'ha pogut aprofundir considerablement en el coneixement de les estructures fiscals i financeres de les poblacions catalanes durant els segles baixmedievals ${ }^{2}$. Fruit d'aquesta línia de recerca, en els darrers anys s'ha evidenciat que l'emissió regular de deute públic a llarg termini des de mitjan del s. XIV (en forma de censals i violaris) no només esdevingué una font de finançament fonamental pels municipis en moments d'urgència econòmica, sinó que també jugà un paper decisiu en el procés de cristal-lització dels seus sistemes fiscals ${ }^{3}$. Ara bé, malgrat els avenços realitzats, encara avui dia existeixen algunes llacunes historiogràfiques que no permeten valorar, en tota la seva magnitud, les repercussions d'aquest transcendental fenomen en la vida política, social i econòmica de Catalunya.

Així, per exemple, cal advertir que la majoria dels estudis dedicats al deute municipal han pres com a laboratori d'observació poblacions ubicades en terres de reialenc, per la qual cosa avui dia encara sabem ben poc sobre l'aparició i consolidació de l'endeutament públic en llocs de senyoriu, ja siguin laics o eclesiàstics ${ }^{4}$. D'altra banda, al marge de l'adscripció jurisdiccional de cada localitat, també són escasses les investigacions que s'han dedicat específicament a la gestió del deute des de finals del s. XIV, quan el creixement exponencial del capital manllevat convertí la seva amortització en una quimera, i fins i tot comportà greus dificultats als consistoris a l'hora de pagar puntualment els elevadíssims interessos anuals a què estaven obligats ${ }^{5}$.

\footnotetext{
${ }^{1}$ Aquest treball s'inscriu en el projecte d'investigació: "Monarquía, ciudades i elites financieras en la Cataluña bajomedieval" (HAR2008-04772); i s'ha pogut realitzar gràcies a una beça predoctoral concedida ạteriorment al projecte d'investigació "Crédito público en la Cataluña bajomedieval: los protagonistas del mercado de la deuda" (HUM2005-02507).

${ }^{2}$ De fet, el treball de Font Rius fou escrit el 1964, tot i que revisat per l'autor el 1982: Josep $\mathrm{M}^{\mathrm{a}}$ FONT RIUS, La administración financiera en los municipios catalanes, dins Historia de la Hacienda española (épocas antigua y medieval). Homenaje al Prof. García de Valdeavellano, Madrid, Instituto de Estudios fiscales, 1982, pp.193-231.

${ }^{3}$ Vegeu les síntesis d'Antoni FurIó, Deuda pública e intereses privados. Finanzas y fiscalidad. municipales en la Corona de Aragón, "Edad Media. Revista de Historia", 2 (1999), pp.35-79 i de Manuel SÁNCHEZ, Deuda pública, monarquía y ciudades en los países de la Corona de Aragón (siglos XIV y XV), dins M. SANCHEZ, Pagar al Rey en la Corona de Aragón durante el siglo XIV, Barcelona, CSIC, 2003, pp.523-561. Una aportació més recent: M. SÁNCHEZ (ed.), La deuda pública en la Cataluña bajomedieval, Barcelona, CSIC, 2009.

${ }^{4}$ Tot i així, comptem amb notables excepcions: Jordi MORELLó, Fiscalitat i deute públic en dues viles del Camp de Tarragona. Reus $i$ Valls, segles XIV-XV, Barcelona, CSIC, 2001; IDEM. Municipis sota la senyoria dels creditors de censals: la gestió del deute públic a la baronia de la Llacuna (segle XV), Barcelona, Fundació Raimon Noguera, 2008; Andreu GALERA, Endeutament i fiscalitat senyorial a la Catalunya del segle XV: el cas del comtat de Cardona (1419-1433), dins M. SÁNCHEZ (ed.), Fiscalidad real y finanzas urbanas en la Cataluña medieval, Barcelona, CSIC, 1999, pp.363-391.

${ }^{5} U n$ intent recent per a pal-liar aquesta mancança és el treball dedicat a l'endeutament de la vila de Cerverạ: Pere VERDEs, "Per co que la vila no vage a perdició". La gestió del deute públic en un municipi català (Cervera, 1387-1516), Barcelona, CSIC, 2004.
} 
I, per últim, un altre dels dèficits historiogràfics més importants és l'anàlisi del rerefons social del deute o, si es vol, l'estudi del món dels creditors. Fins l'actualitat, els treballs que han tractat aquest assumpte s'han limitat a proporcionar petites mostres sobre la identitat d'aquest heterogeni col·lectiu referides a llocs i moments molt concrets que, si bé aporten dades força rellevants, no permeten observar els canvis ocorreguts en el perfil social dels censalistes amb el pas dels anys.

En aquest precís context historiogràfic, i amb l'objectiu de pal-liar les llacunes que acabem d'enumerar, presentem aquest treball, dedicat a estudiar l'endeutament de la vila de Castelló d'Empúries entre els anys 1386 i $1421^{6}$. Com veurem en la primera part, la base documental de la recerca l'han constituït dos capbreus de censals o memorials de rendes que, malgrat ser redactats per les autoritats municipals entre 1410 i 1421, esdevenen unes fonts excepcionals per a conèixer l'evolució de l'endeutament castelloní des de la dècada de 1380. A la llum d'aquests registres, en la segona part podrem aproximar-nos a la situació financera de la capital d'una de les senyories laiques més importants de Catalunya, el comtat d'Empúries, i a les polítiques d'administració del deute endegades pel consistori en un moment en què estava plenament consolidat dins la tresoreria local. Finalment, els dos capbreus de censals també ens permetran resseguir, en la tercera i última part, l'evolució del perfil social dels propietaris de rendes en el transcurs de tots aquests anys.

\section{ELS CAPBREUS DE CENSALS DEL S. XV}

A grans trets, els memorials de rendes elaborats pels municipis $-\mathrm{i}$ també per altres institucions públiques i privades-daten d'un període en què el deute públic a llarg termini havia esdevingut gairebé inextingible i, per tant, estava del tot establert dins dels sistemes fiscals comunitaris. En aquest context, des de finals del s. XIV, molts consistoris procediren a redactar capbreus on van recollir-se totes i cadascuna de les rendes que la universitat estava obligada a pagar en un moment determinat. Amb aquests registres es pretenia, d'una banda, facilitar l'administració quotidiana del deute als regidors municipals i, de l'altra, clarificar la situació jurídica de cada renda per tal d'evitar confusions o possibles conflictes amb el seu propietari. Tenint en compte aquest doble objectiu, és normal que els inventaris, fos quin fos el

${ }^{6}$ Malgrat que encara no disposem de síntesis prou sòlides, diversos autors s'han dedicat a estudiar qüestions rellevants pel coneixement de la història política, social i econòmica d'aquesta població empordanesa a la Baixa Edat Mitjana. Vegeu, entre d'altres: Andreu BASSAS, Els privilegis de Castelló $i$ del comtat d'Empúires, "Estudis Universitaris Catalans". VIII (1914), pp.250-305; Albert COMPTE, Geografia urbana de Castelló d'Empúries, "Annals de l'Institut d'Estudis Empordanesos" [en endavant AIEE], 11 (1976), pp.5-100; IDEM, La Canónica gironina $i$ la geografia urbana de Castelló d'Empúries en la baixa Edat Mitjana, "AIEE", 34 (2001), pp.105-158; Antoni EGEA CODINA, Notícies sobre demografia i jurisdicció del comtat d'Empúries a mitjan del s. XIV "AIEE", 31 (1998), pp.189-230; Miguel PUJOL El cerimonial dels consols de la universitat de Castelló d'Empúries, AIIEE”, 30 (1997), pp. 205-272; IDEM, La conversio dels jueus de Castelló d'Empúries, Girona, Ajuntament de Castelló d'Empúries, 1997; Anthony PINTO, Commerce et draperie dans le comté d'Empúries de 1260 à 1497, 3 vols., Chambéry, Université de Savoie, 2002 [tesi doctoral inèdita]. 
municipi que els hagués confeccionat, continguessin la informació essencial de cada renda: fonamentalment, la tipologia, la quantia de la pensió, els terminis de pagament i la identitat del creditor en el moment de la redacció. No obstant això, aquestes dades bàsiques es podien complementar en moltes altres notícies en funció de les circumstàncies concretes que van portar a l'elaboració de cada memorial. Així, ens podem trobar inventaris que també incorporin el preu o capital invertit en la renda, el tipus d'interès i, fins i tot, una breu descripció de la seva "genealogia", és a dir, la relació de tots els seus propietaris (si és que n'havia tingut més d'un) des del dia de l'emissió per part de la universitat fins el dia en què es redactà el capbreu, i mentre aquest tingués vigència ${ }^{7}$.

Els dos memorials conservats per Castelló d'Empúries s'inscriuen en aquesta dinàmica general, ja que la seva redacció, a partir del 1410, respongué bàsicament a la necessitat del govern municipal de compendiar totes les rendes en un sol registre per tal de clarificar l'estat del deute censal. Ara bé, en el cas de Castelló d'Empúries es donava una circumstància particular. El 1410 el consistori havia de fer front a la greu crisi financera que afectava a la tresoreria municipal, i aquest fet passava fonamentalment per a resoldre dues espinoses qüestions: d'una banda, s'havia de buscar una fórmula per saldar totes les pensions endarrerides que es devien a un nombrós grup de creditors de la vila; i, de l'altra, calia reduir sensiblement els interessos del deute a través d'una rebaixa del tipus d'interès mitjà de les rendes, a fi i efecte de preservar la futura viabilitat financera del municipi. Davant la impossibilitat, però, d'aconseguir una condonació dels endarreriments o bé d'imposar una reducció d'interessos, la única sortida pels dirigents castellonins passava per obrir un procés de diàleg amb cadascun dels censalistes per tal d'arribar a una solució de compromís ${ }^{8}$. Doncs bé, aquesta conjuntura particular resulta fonamental per entendre el contingut dels capbreus, atès que molts dels assentaments redactats per l'escrivà, a banda de contenir les dades bàsiques sobre una determinada renda (tipologia, pensió, terminis...), també fan referència als pactes entre el creditor $\mathrm{i}$ la universitat per tal de liquidar les pagues pendents i/o reduir el tipus d'interès. Per tant, els memorials de Castelló d'Empúries no sols constitueixen un gran inventari de les rendes municipals, sinó també donen fe de les greus dificultats financeres que el creixement descontrolat del deute comportà per a la hisenda local, així com

${ }^{7}$ Vegeu, per exemple, els inventaris conservats per Reus, Cervera o Vic: J. MoRELLó, Fiscalitat i deute públic, cit. p.49; P. VERDÉS, "Per ço que la vila no vage a perdició", cit." pp.46-47; Josep Ma PASSOLA, Introducció del censal l del violari en el Vic medieval, "Ausa", 12 (1986), p.119.

${ }^{8}$ Recordem que el 1363 , el rei Pere el Cerimoniós havịa establert en constitució general i perpètua que les reduccions de censals havien de ser voluntàries, i que en cap cas l'acord amb una part dels censalistes podia ser vinculant per a la resta: Max TURULL - P. VERDES, Sobre la hisenda municipal a Constitucions i altres Drets de Cathalunya (1704), dins M. SÁNCHEZ (ed.), Fiscalidad reat y finanzas urbanas, cit. p.141. 
de la política de sanejament que les autoritats endegaren a partir del 1410 per a pal-liar-les ${ }^{9}$.

Tenint en compte aquest fet, resulta més fàcil de comprendre l'estructura formal que es donà a cada assentament. Fonamentalment, aquest es podia dividir en cinc parts, cadascuna de les quals proporcionava un tipus d'informació molt concreta al municipi sobre una determinada renda.

La primera part de l'assentament havia de donar resposta a dues qüestions bàsiques: calia, en primer lloc, conèixer a qui s'havia de pagar una determinada renda en el moment de la redacció i, al mateix temps, calia saberne la naturalesa, és a dir, les característiques concretes del crèdit. Així, tots i cadascun dels assentaments començaven amb dues anotacions. En la primera, que encapçalava el text, l'escrivà hi especificava el titular actual de la renda, ja fos persona física o jurídica; en el primer cas, l'anotació es complementava amb el lloc de residència, l'ofici o la condició social, tot i que aquestes últimes dades no sempre es precisaven. La segona anotació havia d'aportar la informació essencial sobre l'origen i les característiques de la renda: s'apuntava la data de l'emissió, la tipologia del crèdit i el seu interès (for), la quantitat a pagar, el capital prestat o "preu", els terminis de pagament -gairebé sempre dues pagues semestrals-, la identitat del comprador -en el cas de les persones físiques també es podia completar amb el seu perfil social i procedència geogràfica- i, finalment, la indicació del notari que guardava l'escriptura de venda. Si el comprador d'origen coincidia amb el titular d'aquell moment i, al mateix temps, no s'efectuava cap operació de reducció i/o pagament de pensions endarrerides sobre la renda, en aquest cas l'assentament es donava per conclòs; llavors s'anotava al marge dret la quantitat que s'havia de pagar en el dia o dies indicats, i es passava a redactar la memòria d'un nou censal.

Habitualment, però, van transcórrer força anys entre la venda de la renda i l'elaboració dels capbreus, raó per la qual era freqüent que el titular anés canviant. En aquests casos, també calia que el clavari municipal redactés les transmissions de la propietat del censal des de la data de la seva emissió fins al present creditor. Com pot imaginar-se, aquesta tercera part també informava, a més dels canvis de titularitat, del grau de fragmentació dels censals: una pensió - normalment aquelles amb un capital inicial elevatpodia fraccionar-se en d'altres en el moment de cada transacció, i aquestes, al seu torn, també podien dividir-se. Aquesta ramificació dels deutes es pot observar clarament en els capbreus quan constatem que un grup d'assentaments fan referència a la mateixa renda en origen, encara que cadascun d'ells descrigui l'evolució d'una de les divisions succeïdes des d'un determinat moment fins el dia de la redacció dels esmentats memorials. Mercès a la

\footnotetext{
${ }^{9}$ Aquests inventaris es conserven al dipòsit de "protocols" de l'Arxiu Històric de Girona. Fons Notarial [en endavant AHG, FN], Castelló, $n^{\circ} 1850$ i n ${ }^{\circ} 1945$ ). A més, però, d'aquests registres, també hem utilitzat complementariament un llevador de censals corresponent a l'exercici econòmic de 1417-1418, és a dir, una relació de totes les pensions anuals que la universitat estava obligada a pagar durant aquella anualitat, tot limitant-se a indicar la identitat del creditor i la data de pagament (AHG, FN, Castelló, n²023).
} 
reconstrucció de la "genealogia" de cada renda, els capbreus donaven fe de la propietat d'una pensió per part d'un determinat creditor, i evitaven possibles malentesos entre aquest i el consistori. En cas, però, que s'hagués d'aclarir algun dubte, l'escrivà també indicava el notari que custodiava el document complet de qualsevol de les transaccions de la renda.

Finalment, després de l'evolució "genealògica" de la renda, seguia la menció als acords amb els censalistes, si és que aquests es van arribar a produir. Si fou així, el primer que s'anotava era el pacte per a la reducció del tipus d'interès i, bàsicament, s'indicava el nou for aplicat al censal i la pensió resultant. Així mateix, s'esmentaven els nous terminis de pagament, que habitualment s'ajustaven al dia en què s'havia signat l'avinença: el $50 \%$ de la pensió es percebria en aquesta data, i l'altre $50 \%$ sis mesos després. I, en cas que el consistori hagués suspès el pagament de la pensió censal, tot seguit es deixava constància del pacte per a liquidar les pagues endarrerides. Normalment, s'anotava la data de la primera i de l'última pensió que el creditor no havia cobrat, encara que de vegades l'escrivà relacionava totes i cadascuna de les anualitats degudes. Com no podia ser d'una altra manera, en ambdós casos (reducció d'interessos i satisfacció d'endarreriments) també s'apuntava el notari que havia formalitzat els acords, normalment el mateix ${ }^{10}$.

A grans trets, doncs, aquestes són les cinc parts que podem distingir en els assentaments que conformen els capbreus. En resum, podem concloure que les diferències formals que es revelen entre uns i altres són resultat de dues circumstàncies: en primer lloc, si es produí algun canvi en la titularitat de la renda entre la data de venda original i el dia de la redacció de l'assentament; i, en segon lloc, si es formalitzà algun pacte entre el creditor i la universitat, ja sigui per la reducció del tipus d'interès de la renda, o per saldar les pensions pendents. En funció d'aquestes variables, els assentaments podien contenir o no determinades parts, però l'estructura fonamental sempre era la mateixa.

\section{LA CRISI FINANCERA DEL MUNICIPI}

L'any 1999, Manuel Sánchez va descriure l'entramat fiscal i financer de Castelló d'Empúries a través d'un llibre de comptes municipal corresponent a l'exercici econòmic de 1381-1382 11 . A la llum d'aquest registre, l'autor pogué constatar a la vila empordanesa la presència d'un sistema fiscal similar al d'altres poblacions catalanes, i caracteritzat per una doble comptabilitat: l'una, dedicada genèricament als ingressos i pagaments propis de la clavaria o tresoreria castellonina; l'altra, dedicada específicament al pagament de les pensions censals amb el producte dels impostos indirectes (imposicions) recaptats pel consistori i assignats a aquest fi. L'existència d'aquesta segona

\footnotetext{
${ }^{10} \mathrm{El}$ segon capbreu també recull la relació de testimonis presents en els actes d'avinença, la qual cosa ens ha permès completar el perfil social d'algun creditor.

${ }^{11}$ M. SÁNCHEZ, Fiscalidad y finanzas de una villa señorial catalana: Castelló d'Empúries, 1381-1382, dins M. SÁNCHEZ (ed.), Fiscalidad real y finanzas urbanas, cit. pp. 301-363.
} 
"caixa" revelava que el recurs fiscal més important del municipi, les imposicions, restava completament hipotecat al servei d'unes despeses preestablertes, els interessos del deute, cosa que limitava considerablement el marge de maniobra de la hisenda castellonina. Dit en altres paraules, enfront de qualsevol dispendi més o menys imprevist, la universitat no tindria cap altre remei que augmentar la pressió fiscal o bé endeutar-se encara més del que ja estava. Davant aquest panorama, Manuel Sánchez s'acabava preguntant si un futur creixement del deute públic, motivat per noves necessitats pecuniàries de la universitat, no acabaria topant amb el límit contributiu dels castellonins, cosa que abocaria la hisenda local al llindar de la fallida financera.

\subsection{La suspensió de pagaments (1393-1410)}

En un recent article, hem pogut respondre aquest interrogant mercès a l'anàlisi d'un protocol notarial redactat durant el bienni 1386-1387 i anomenat pels mateixos dirigents locals "manual de reduccions", que dóna fe de la greu crisi financera que la tresoreria castellonina experimentà a partir de $1382-1383^{12}$. Segons aquest volum, a l'abril de 1381, el comte Joan I d'Empúries havia atorgat als cònsols castellonins una llicència per vendre una important quantitat de censals perpetuals (o rendes emeses sense carta de gràcia $\mathrm{i}$, per tant, irredimibles) a molt baix interès $(3,3 \%)$ per tal d'amortitzar les rendes amb una taxa més elevada, això és, els violaris $(14,28 \%)$ i els censals morts $(7,14 \%)$. Amb aquesta mesura es pretenia aconseguir una rebaixa significativa del tipus d'interès mitjà de les rendes municipals i, en conseqüència, una reducció sensible del volum de les pensions censals. D'aquesta manera, el govern local esperava poder equilibrar els ingressos anuals de la hisenda amb les importants despeses ocasionades pels interessos del deute $\mathrm{i}$, en darrer terme, alleujar les feixugues càrregues fiscals que pesaven sobre els habitants de la capital emporitana. No obstant, diverses circumstàncies van impedir que aquesta política arribés a bon port i, en el mencionat bienni de 1382-1383, les autoritats de la vila van veure's abocades a suspendre el pagament de les pensions anuals - excepte les corresponents als censals perpetuals - com a mesura de força per a compel-lir als creditors a acceptar una disminució "voluntària" del tipus d'interès de llurs violaris i censals morts ${ }^{13}$.

\footnotetext{
${ }^{12}$ Albert MARTÍ ARAU, Endeutament censal i crisi financera a una vila senyorial: Castelló d'Empúries (1381-1393), dins M. SÁNCHEZ (ed.), La deuda pública, cit. pp.153-219.

${ }^{13}$ Segurament, les raons de la fallida financera de la hisenda s'han de cercar en dos factors per un costat, la necessitat de satisfer un substanciós donatiu de 20.000 1l. al comte Joan d'Empúries; i', per l'altre, la guerra que esclatà al comtat empordanès entre aquest comte i el rei Pere el Cerimoniós durant els anys centrals de la dècada de 1380. Sobre aquest conflicte vegeu: Alberto BosCOLO, La reina Sibil la de Fortià, Barcelona, Rafael Dalmau, 1971; Santiago SOBREQUÉS, Els barons de Catalunya, Barcelona, Vicens Vives, 1991, pp. 172-173.
} 
Aquesta reducció general d'interessos, que es féu efectiva entre 1386 i 1393, va suposar la desaparició dels violaris $(14,28 \%)$ i, pràcticament, de tots els censals morts al 7,14\% d'interès, ja que es reconvertiren en nous censals morts taxats a un $5 \%$ o bé en censals perpetuals a un 3,3\%. Així doncs, les autoritats de Castelló d'Empúries acompliren l'objectiu perseguit , com a mínim, des d'una dotzena d'anys enrere: reduir el volum global de les pensions censals. No obstant, malgrat tots aquests esforços, tot seguit veurem que els capbreus de censals documenten noves suspensions de pagaments des del mateix 1393, per la qual cosa només podem concloure que la política de sanejament del deute finalitzada aquest any s'havia tancat en fals.

D'ençà el 1393, les notícies d'impagaments que proporcionen els memorials de Castelló - la gran majoria de les quals corresponents a censals que ja havien estat reduïts entre 1386 i 1393 - s'anaren succeint fins arribar a les 139 el 1410, tal i com es pot comprovar en la següent gràfica:

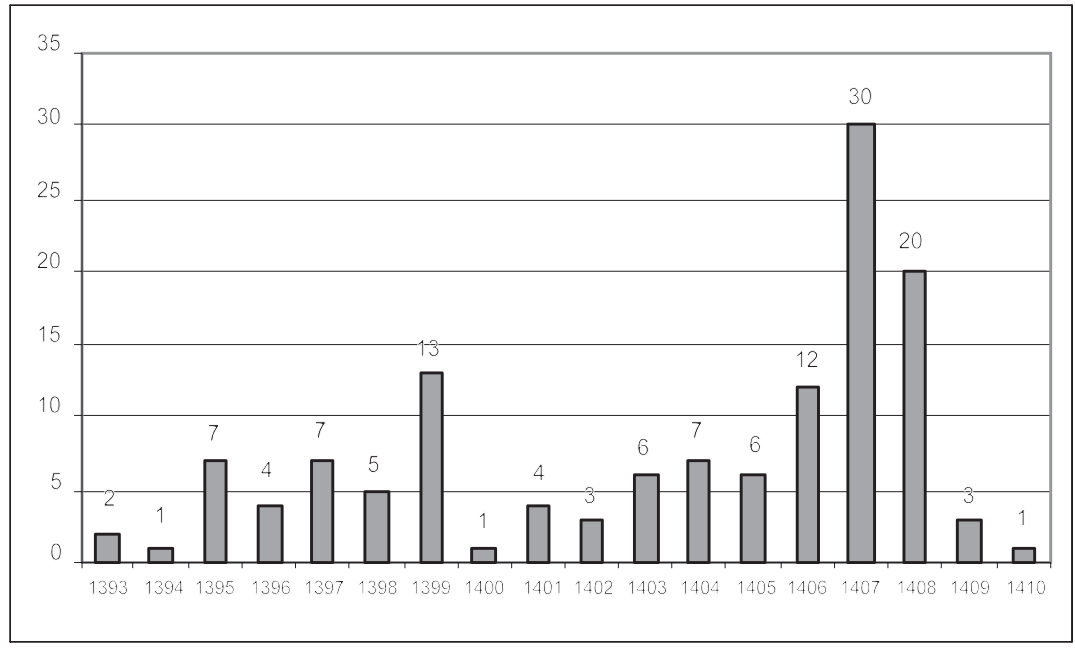

Gràfica ${ }^{\circ} 1$ : Rendes suspeses a Castelló d'Empúries (1393-1410) $)^{14}$

Com pot veure's, cada any des del 1393 la vila va deixar de pagar almenys una pensió censal. Tanmateix, aquest degoteig incessant de suspensions no dibuixa una línia ascendent, sinó que es poden distingir dues etapes dins aquesta dinàmica, separades justament per l'any 1400: una primera, en què després d'unes poques suspensions, els anys 1393 i 1394 (3), aquestes

\footnotetext{
${ }^{14}$ Som conscients que la suma de totes les notícies d'impagaments contingudes en aquesta gràfica ascendeix a 132, i no a les 139 que hem apuntat. De fet, a aquesta xifra hi hem afegit aquelles set pensions d'un petit grup de sis censalistes - a qui en un altre lloc anomenàvem "mals creditors"- els quals no havien acceptat cap tipus d'acord amb els cònsols castellonins durant el primer procés de sanejament del deute (1386-1393) $\mathrm{i}$, en conseqüència, s'havia deixat suspès e pagament de llurs rendes des de la primera bancarrota del municipi el 1382-1383 (A. MARTî ARAU, Endeutament censal,pp.182-184) Vegeu la relació cronològica de totes les rendes suspeses per la universitat en el quadre $n^{\circ} 1$ de l'apèndix.
} 
augmentaren clarament entre 1395 i 1400 (37); i una segona fase en què s'observa un cert alentiment d'aquesta tendència entre 1401 i 1406 (38), seguit d'un sobtat i notable increment de suspensions durant el bienni 1407-1408 (50). Lluny de ser atzaroses, aquestes xifres responen a l'actuació dels cònsols castellonins a l'hora d'escollir quines rendes havien de suspendre primer i quines en darrer lloc, una elecció que va respondre a una lògica ben definida i basada en tres criteris: la naturalesa de les rendes, el perfil social del creditor $\mathrm{i}$, per últim, la seva procedència geogràfica.

Pel que fa la primera d'aquestes pautes, el govern castelloní degué considerar que, d'igual manera que havia fet al llarg de la dècada de 1380 , primer de tot calia desfer-se d'aquelles rendes més costoses pel municipi, és a dir, aquelles que presentaven la taxa d'interès més elevada. Com acabem d'explicar, després de la primera temptativa de sanejament del deute el 1393, els violaris havien desaparegut de la hisenda local i tan sols es pagaven censals morts a un interès del 5\% -excepcionalment, alguns a un 7,14\% - i censals perpetuals a un 3,3\%. En el tombant del segle XIV, doncs, la renda més onerosa pel municipi havia passat a ser el censal mort i, per tant, resulta lògic que els regidors optessin, primerament, per suspendre el pagament d'aquest tipus de deute.

Això explica que tots aquells creditors que posseïen censals perpetuals no deixessin de percebre en cap moment les seves anualitats. L'any 1410 el municipi satisfeia la pensió de 55 rendes irredimibles, producte de les emissions realitzades durant els primers anys del decenni de 1380 o bé dels pactes formalitzats amb els creditors entre 1386 i 1393. Doncs bé, la universitat establí el 3,3\% d'interès d'aquests censals com a límit a partir del qual no es pagaria cap altra renda, tot plantejant aquesta segona suspensió -igual que la primera- com una veritable mesura de força per tal d'obligar als creditors, propietaris de censals morts, a acceptar una rebaixa raonable de la taxa d'interès ${ }^{15}$.

Un cop establert aquest topall, el consistori realitzà una distinció bàsica entre creditors segons el seu perfil social: tan sols suspendria el pagament dels censals morts pertanyents a censalistes laics, mentre que continuaria satisfent les pensions que eren propietat d'institucions religioses i benèfiques. En aquest sentit, els 132 censals morts suspesos entre 1393 i 1410 parlen per si mateixos, ja que tots ells pertanyien a persones laiques. Òbviament, la decisió del govern municipal només es pot entendre pel temor i/o escrúpols que provocava la suspensió de les pensions assignades a l’Església, així com per la voluntat de no posar en entredit la beneficència local ja que, com veurem més endavant, una part gens menyspreable de pensions censals estava en mans d'institucions pietoses de la vila.

\footnotetext{
${ }^{15}$ Bona prova d'això s'observa en tots aquells assentaments que descriuen l'evolució d'aquestes rendes irredimibles des del moment de la seva venda fins a la data en què es van redactar els capbreus: cap d'ells noticia ni una suspensió de pagaments ni una reducció del seu tipus d'interès.
} 
Ara bé, dins del col·lectiu eclesiàstic, el consistori introduí un matís important: tots aquells clergues que posseïen un censal mort a títol particular i no en qualitat de representants d'una determinada institució religiosa, també podien deixar de rebre llurs pensions. Aquest és el motiu pel qual els capbreus de censals utilitzen diferents fórmules per tal d'aclarir a quina de les dues categories pertanyia un determinat censalista eclesiàstic. D'entre totes elles, la que més clarament manifesta la distinció entre els dos tipus de censalistes religiosos l'observem en l'operació del 16 de novembre del 1386, quan el prevere Pere Gibern comprà a la vila un censal mort (5\%) "en nom seu propri e axí com a layca persona" ${ }^{16}$. Altrament dit, encara que el creditor fos un clergue o un prevere, a ulls del municipi era considerat com un creditor laic i, per tant, es justificava la suspensió de pagaments d'aquesta renda ${ }^{17}$.

Una vegada establert que les primeres pensions a ser suspeses correspondrien a creditors laics, propietaris de censals morts, calia escollir quins serien els primers afectats dins d'aquest ampli col-lectiu. En aquest sentit, sembla ser que el criteri seguit per decidir aquesta qüestió fou l'origen geogràfic dels censalistes $i$, per mostrar-ho, hem reconvertit la gràfica anterior segons el lloc de residència dels creditors, tot dividint-los en tres grups: els procedents de Castelló d'Empúries, els de Girona i, finalment, els de la resta de localitats, pròximes totes elles a la mateixa capital emporitana ${ }^{18}$.

\footnotetext{
${ }^{16}$ AHG, FN, Castelló, no 1945 , f.34 r. Normalment, l'escrivà dels capbreus utilitzava altres fórmules, com ara que un determinat religiós comprava un censal «de béns propris e no de benifet» o bé «comprant en nom seu propri»o "dels béns adquisits per sa indústria»: AHG, FN, Castelló, $\mathrm{n}^{\circ} 1850$, f.73 v. i f.77 v.

${ }^{17}$ Aquest fet originà alguna situació curiosa, com per exemple el cas del prevere Nicolau Gori, que posseïa dos censals morts venuts pel municipi. La diferència entre un i altre, però, va radicar en què l'un el comprà a títol particular, mentre que l'altre el percebia en tant que administrador d'un benefici religiós establert pel seu germà, el mercader Francesc Gori, a l'església de Santa Maria de Castellơ d'Empúries. En conseqüència, el primer censal fou suspès el desembre del 1407, mentre que el consistori mantingué sense interrupcions el pagament de l'altra renda fins la segona dècada del s. XV: AHG, FN, Castelló, no 1850 , ff.72 r.-73 v.

${ }^{18}$ Aquesta divisió és la que ja establí Manuel Sánchez a partir de l'estudi de l'esmentat llibre de comptes de 1381-1382, en què constatava, tal i com veurem més endavant, una presència molt significativa en l'endeutament municipal tant de censalistes procedents de la mateixa vila comtal, com de la ciutat de Girona (M. SÁNCHEZ, Fiscalidad y finanzas de una villa, cit. pp.321-322).
} 


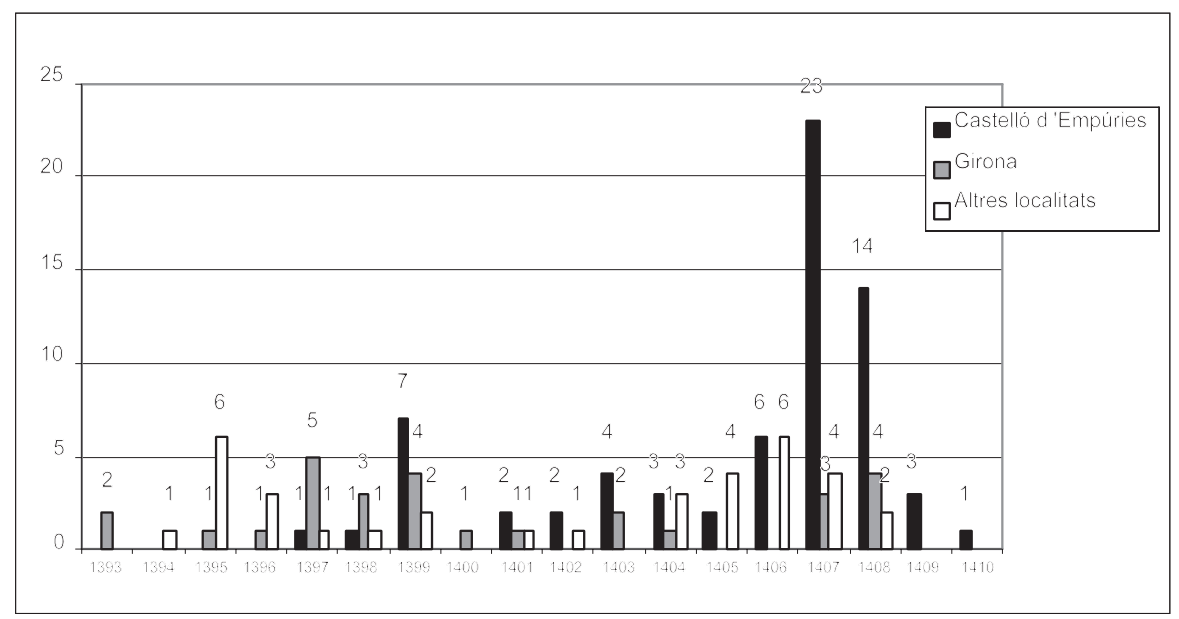

Gràfica $\mathrm{n}^{\circ} 2$ : Rendes suspeses a Castelló d’Empúries, segons la procedència geogràfica dels creditors (1393-1410).

Anteriorment, havíem dividit la cronologia de la suspensió de pagaments en dues fases, abans i després del 1400. Doncs bé, considerem que aquesta divisió es pot continuar mantenint des de la perspectiva de la procedència geogràfica dels creditors: així, entre 1393 i 1400, es constata un clar predomini de pensions suspeses a censalistes forans (31), enfront de les només nou dels creditors locals ${ }^{19}$; en canvi, després del 1400 , les rendes impagades a castellonins augmentaren progressivament dins aquesta dinàmica fins arribar a la seixantena el 1410, gairebé el doble que les pertanyents als forans (32). Ara bé, per tal de comprendre correctament les causes d'aquesta dinàmica, caldria afegir alguns matisos addicionals dins de cadascuna de les dues etapes esmentades.

Pel que fa la primera fase, si bé quasi totes les rendes suspeses pertanyien a creditors forans, s'observa un cert protagonisme d'aquelles més quantioses, en la majoria dels casos pertanyents a rellevants habitants de Girona $(17)^{20}$. Malgrat que només sigui una hipòtesi, és probable que el

\footnotetext{
${ }^{19}$ Aquesta proporció encara seria més acusada a favor dels creditors forans atès que, de les nou pensions suspeses a castellonins, sis pertanyien al mateix creditor, el jurista Bernat Portes. Es possible que aquesta suspensió dels censals morts d'un mateix censalista respongués a unes circumstàncies concretes que, ara com ara, no podem determinar: AHG, FN, Castelló, no 1945 , ff. 43 v. $-48 \mathrm{v}$.

${ }^{20}$ Per exemple, el febrer del 1397, el municipi suspengué les pensions de la família Sarriera: Joan Sarriera deixà de percebre les 38 11. $9 \mathrm{~s}$. anuals d'un censal mort de $76911.14 \mathrm{~s} .9 \mathrm{~d}$. (5\%); Bernat, les 40 ll. d'un altre censal mort de 800 ll. (5\%); i Guillem, les 52 1l. 4 s. 4 d. d'un censal de 1.044 11. $7 \mathrm{~s} .7 \mathrm{~d}$. (5\%). La relació de suspensions documentadẹs durant aquests anys continua amb els censals morts d'altres membres il-lustres del patriciat gironí, com ara, els de Guillem Llobet i Joan Albert a l'agost del 1397 o el de Pere Desvern al gener del 1399. Per veure els detalls d'aquestes suspensions, així com de la resta, vegeu el quadre no 1 de l'apèndix.
} 
consistori castelloní, davant la impossibilitat de satisfer totes les pensions, volgués evitar una suspensió de pagaments generalitzada $\mathrm{i}$, almenys en un primer moment, preferís concentrar-la en unes poques rendes de quantia elevada. Öbviament, suspendre el pagament de les pensions a conspicus membres de la societat gironina comportava certs riscos pel municipi, atesa la important capacitat de represàlia que aquests posseïen a l'hora de fer complir els compromisos contrets. Bona prova d'això és la carta que la reina Maria, esposa i lloctinent de Martí l'Humà, va enviar als jurats de Girona el 27 de setembre del 1396. En aquesta missiva, la reina explicava als regidors gironins els efectes perniciosos dels nombrosos plets judicials incoats pels creditors d'aquella ciutat contra la universitat de Castelló d'Empúries a causa de l'impagament dels censals, fins el punt que els deutors no gosaven trepitjar indrets situats més enllà dels límits jurisdiccionals del comtat emporità per por a no incórrer en alguna sanció. Per evitar, doncs, que es malmetessin les relacions econòmiques entre la capital comtal i les poblacions del domini reial, la monarquia demanava als jurats de Girona que intercedissin davant els censalistes d'aquesta ciutat per tal que es respectés el guiatge que havia atorgat als habitants de Castelló d'Empúries. A canvi, la reina es comprometia a actuar de mitjancera amb el govern castelloní o, fins i tot, amb el mateix comte d'Empúries, a fi que es satisfessin les anualitats degudes ${ }^{21}$.

Les dades de la gràfica, però, evidencien que l'estat de la tresoreria municipal empitjorà encara més durant la primera dècada del $\mathrm{s}$. XV , cosa que obligà als governants castellonins a incloure progressivament dins de la suspensió de pagaments als creditors locals. Així, entre 1401 i 1406, el nombre d'anualitats impagades d'aquest darrer grup ja s'equiparà amb el dels censalistes forans (19) i, en el bienni 1407-1408, experimentà un augment definitiu (37). A tenor d'aquestes dades, podem concloure que l'any 1410 la situació financera de la hisenda local era insostenible i que, per a pal-liar-la, calia endegar un ambiciós procés de sanejament del deute.

\subsection{La reducció del deute (1410-1421)}

Abans d'entrar pròpiament en l'anàlisi de la política financera iniciada el 1410, cal fer-se ressò de les notícies que proporcionen els capbreus sobre els intents fallits de reducció del deute previs a aquest any. Les primeres, malgrat ser molt escasses, es situen entre els anys 1403 i $1407 \mathrm{i}$, possiblement, s'emmarquen en la política de redreç general que el rei Martí l'Humà, com a nou senyor del comtat d'Empúries des del 1402, també impulsà en altres àmbits de la vida social i política de la vila ${ }^{22}$. En concret, els memorials de rendes només ens diuen que, al llarg d'aquests anys, els clavaris Pere Caragol

${ }^{21} \mathrm{M}^{\mathrm{a}}$. Josepa ARNALL, Lletres reials a la ciutat de Girona (1293-1515), vol. II, Barcelona, Fundació Noguera, 2000, pp.660-661.

${ }^{22}$ Particularment en el govern municipal, molt trasbalsat per les bandositats locals: A. COMPTE, Un inventari de l'A rxiu de Castelló d'Empúries de mitjans del segle XVIII, "AIEE”, 20 (1987), p.219; A. BASSAS, Els privilegis de Castelló, p.272 i p.293. 
i Bartomeu Albert van pagar algunes pensions endarrerides a sis censalistes de la universitat ${ }^{23}$.

Segurament, són més reveladores les dades que contenen els memorials de rendes sobre l'intent de sanejament protagonitzat, entre $1407 \mathrm{i}$ 1409, per Lleonard de Sos, oficial de la cort del Mestre Racional. Segons una carta del rei Martí l'Humà, datada el 10 d'agost del 1407, l'estat de la hisenda de Castelló d'Empúries en aquell moment era certament precari, i no només pel feixuc pes dels interessos censals, sinó també pel setge judicial a què havien sotmès la universitat molts creditors a fi que els fossin saldats els deutes pendents ${ }^{24}$. Amb l'objectiu de posar remei a aquesta difícil conjuntura - i, de retruc, salvaguardar els drets i rendes reials a Castelló d'Empúries-, el monarca envià a la capital emporitana l'esmentat Lleonard de Sos, un expert en matèria econòmica, per tal que es responsabilitzés de la política financera de la vila i obrís un diàleg amb els creditors per a "reduhir a una cosa rehonable los dits censals e violaris com sia la pus expedient manera que a present se puxe tenir, e per relevar, sustentar e reparar la dita vila" ${ }^{25}$.

A l'espera que una futura recerca documental permeti aprofundir en aquesta qüestió, ara com ara ignorem quin fou l'autèntic abast de la política endegada per Lleonard de Sos. A la llum dels capbreus, però, sabem que aquest nou gestor va satisfer la pensió a vuit creditors afectats per la suspensió de pagaments, després d'haver-los-la reduït a un interès del 2,5\%. Tanmateix, sembla ser que Lleonard de Sos i els propietaris dels censals morts suspesos van recórrer a una mena de subterfugi formal per tal d'efectuar aquesta operació: tot i que aquell els pagà una pensió calculada a un $2,5 \%$ d'interès, els creditors "reconeixien” que havien rebut la pensió íntegra, és a dir, taxada

\footnotetext{
${ }^{23}$ No deixa de ser simptomàtic que, durant el mateix període, tinguem notícies d'intents de sanejament del deute censal a l'aljama de Castelló d'Empúries. El febrer del 1405, la reina Maria, a qui Martí l'Humà havia cedit el govern del comtat emporità, s'assabentava que es procedia a realitzar una execució de béns contra la comunitat hebrea a causa de l'impagament d'alguns censals morts pertanyents al donzell Dalmau de Raset. Poc després, el 7 de maig, la reina escrivia als creditors per tal que accedisssin a rebaixar l'interès de les pensions $i$, d'aquesța manera, es pogués pal·liar la difícil situació econòmica de l'aljama: M. PUJOL, La conversió dels jueus, pp.78-82.

${ }^{24}$ Aquesta epístola era la resposta a una súplica que els cònsols castellonins havien adreçat anteriorment al monarca, en la qual li demanaven ajuda per posar fi a la deplorable situació a què havia arribat la vila. Possiblement, el rei Martí l'Humà utilitzà els mateixos termes que els regidors municipals havien emprat per descriure la penosa conjuntura econòmica en què estava immersa la població; paraules no exemptes d'un cert deix dramàtic, habitual en aquests casos: «...hajam certament sabut que la dita vila e lo comtat d'Empúries solen e han acustumat ésser en no pocha extimació per los grans càrrechs de censals, de violaris e d'altres diverses deutes, a què's diu ésser tenguts són en tant deteriorats e posats en dechaiment, ans quax en termini de final destrucció e dispoblació que, si no y és dẹ alcun suficient prest e bon remey provehit, convendrà als habitants en aquells lexar lurs pròprias habitacions e heretats que aquî han e en altra part cercar lur miserable vida, la qual cosa seria a nós molt greu, majorment com acò s'esdevengue a la dita vila, qui és cap de tot Empordà e a tọt lo dit comtat, per excessius e importables deutes e diverses cohercions, compulsions e execucions e durs procehiments d'aquè-n ja seguits e qui cascun die contra aquella se seguexen» (AHG, FN, Castelló, n ${ }^{\circ} 1848$, f.191 r.) Agraïm la notícia d'aquest document a Manuel Sánchez Martínez.

${ }^{25}$ AHG, FN, Castelló, no 1848 , f.192r.
} 
en un $5 \%$ o, en algun cas, a un $7,14 \%^{26}$. Malgrat moure'ns en el terreny de l'especulació, és molt probable que aquesta fórmula respongués a la voluntat dels censalistes de no crear cap precedent jurídic, és a dir, de no acceptar la disminució d'interessos per escrit. Sigui com sigui, si comparem el reduït nombre d'operacions que Lleonard de Sos formalitzà entre 1407 i 1409 amb les notícies d'impagaments que es produïren només durant aquest mateix període (53), resulta evident que l'interventor enviat per la Corona se n'anà de Castelló d'Empúries sense haver pogut acomplir el seu objectiu ${ }^{27}$.

Tot i així, el camí traçat per Lleonard de Sos fou reprès per les autoritats municipals de Castelló d'Empúries el 4 de març de 1410, dia en què es reuní el Consell secret -o restringit- de la vila per tal de buscar una sortida definitiva a la crisi financera. Novament, sobre la taula hi havia un doble problema per resoldre: d'una banda, liquidar les pagues degudes a un nombre molt important de creditors laics; i, de l'altra, reduir sensiblement les pensions dels censals mitjançant una rebaixa pactada dels tipus d'interès. Els membres del Consell eren plenament conscients de què dur a terme aquesta iniciativa era molt complicat, ja que qualsevol reducció d'interessos requeria el consentiment dels creditors, $i$ totes les maniobres que en aquest sentit s'havien produït fins llavors havien reportat exigus resultats. Tanmateix, s'escolaven els últims mesos de vida del rei Martí l'Humà i, en aquest moment d'incertesa política, el govern castelloní degué veure l'oportunitat de forçar un pacte favorable amb els censalistes del municipi ${ }^{28}$.

La primera decisió que degueren prendre els governants de la vila fou que, per tal d'assegurar la viabilitat financera de la tresoreria, aquest cop calia reduir els interessos de tots els censals morts que la universitat estava obligada a pagar, excepte els censals perpetuals (3,3\%). Per tant, aquesta mesura implicava no només obrir negociacions amb els creditors laics, propietaris de censals morts, sinó també amb tots aquells altres que, en tant que representants d'una determinada institució benèfica o eclesiàstica, també percebien pensions anuals d'aquest tipus de renda. Més enllà de la condició social dels creditors,

${ }^{26}$ Per exemple, el maig del 1408 la universitat suspengué el pagament de la pensió que percebia Florença, vídua del cavaller castelloní Ramon de Fontcoberta, corresponent a un censal mort de 2711.6 d. anuals i de preu de $54011.10 \mathrm{~s}$. (5\%). Doncs bé, en una dạta indeterminadạ, sabem que Lleonard de Sos pagà a aquesta vídua 13 li. 15 s. és a dir, una pensió d'aquest mateix censal però calculada a un interès del $2,5 \%$. Tanmateix, Florenca certificava -tot i no ser aixíque havia cobrat el doble, això és, 2711 . 10 s., una quantia molt propera a la que habitualment percebia a un $5 \%$ d'interès. En altres paraules, malgrat que cobrà mitja anualitat, la creditora reconeixia que l'havia rebut sencera: $\mathrm{AHG}, \mathrm{FN}$, Castelló, n⿳0 $1945, \mathrm{f} .7 \mathrm{v}$.

${ }^{27}$ Val a dir que Castelló d'Empúries no fou l'única localitat que requerí els serveis de Lleonard de Sos, ja que el 1418 també intercedí, en qualitat de lloctinent del Mestre Racional, davant els creditors lleidatans de Fraga per a quề rebaixessin l'interès de llurs censals fins a un $2,5 \%$. A canvi, el municipi aragones es comprometia a pagar-los les anualitats endarrerides: Joaquín SALLERAS CLARIó, La baronía de Fraga: su progresiva vinculación a Aragón (1387-1458), Barcelona, Universitat de Barcelona, 2007, p.661 [tesi doctoral inèdita]. Vegeu també l'explicacio d'aquests fets a Antonio BERENGUER GALINDO, Censal mort. Historia de la deuda pública del concejo de Fraga (siglos XIV-XVIII), Fraga, Instituto de Estudios Altoaragoneses-Ayuntamiento de Fraga, 1998, pp.45-48.

${ }^{28}$ Des d'aquest punt de vista, no és estrạny que algunes concòrdies entre universitats i creditors per a reduir el deute censal datin, precisament, d'aquests anys, com per exemple succeeix a Cervera o a la baronia de la Llacuna (1413): P. VERDÉS, "Per co que la vila no vage a perdició", cit. p.125; J. MoRELló, Municipis sota la senyoria, pp.133-147. 
el govern municipal fixà en un 2,5\% l'interès a què s'havien de rebaixar els censals morts, això és, el mateix tipus que havia establert Lleonard de Sos uns anys abans. Aquesta reducció d'interessos es formalitzà, simplement, mitjançant un document notarial on s'especificava la naturalesa exacta de l'operació. En conseqüència, quan els capbreus de censals registren cadascun d'aquests acords, tan sols es limiten a constatar que el creditor va acceptar la rebaixa de l'interès del censal mort ${ }^{29}$.

Evidentment, les negociacions més complicades es produïren amb el col-lectiu laic ja que, abans de convenir qualsevol reducció dels censals morts, calia liquidar les pensions endarrerides; i, per fer-ho, s'havien de donar diversos passos. En primer lloc, cada censalista havia d'acreditar documentalment que posseïa algun censal mort del municipi i, lògicament, des de quin moment havia deixat de percebre les pensions corresponents. En segon lloc, si s'esqueia, el consistori restava del total de les pensions degudes, les sumes de diners que el creditor podia haver cobrat des del dia de la suspensió fins el dia de l'acord, ja fos de mans dels esmentats clavaris Pere Caragol i Bartomeu Albert o bé de l'interventor reial Lleonard de Sos. En tercer lloc, una vegada establerta la quantitat final que es devia al creditor, s'efectuava l'operació clau en tot aquest procés: així, si el total degut corresponia a la suma de les pensions pendents, taxades a un tipus d'interès del $5 \%$ o el $7,14 \%$, el municipi reduïa el teòric ròssec - amb el consentiment del creditor- calculant-les a un $1,6 \%$ d'interès. Finalment, el consistori es comprometia a liquidar aquest nou deute en cinc terminis anuals, a comptar des que es formalitzava l'acord amb el censalista davant de notari ${ }^{30}$.

Un cop obtingut l'acord amb els creditors laics pel pagament de les pensions degudes, el mateix dia es certificava la reducció del tipus d'interès de les rendes des d'aquell moment en endavant. Com hem avançat, aquesta operació no només havia d'afectar els censals morts d'aquest col·lectiu, sinó també els pertanyents a institucions benèfiques i eclesiàstiques, que havien

\footnotetext{
${ }^{29}$ Per exemple, en un dels primers acords obtinguts pel municipi el dia 11 d'abril del 1410 el jurista castelloní Francesc Despuig, que cobrava 8 1l. 2 d. anuals per un censal mort de 16011 3 s. 6 d. (5\%), «pactà ab la vila que, del die present en havant, no puxa demenar per rahon del dit censsal sinó a rahó VI d. per li. [2,5\%], qui serien l'any IIII ll. I d., pagados la mitat d'aquelles a XI d'octobri e l'altra mitat a XI d'abrill segons per carta stà ferm feta, en poder del discret en Pere Jacme, notari de la dita vila, a XI d'abrill de l'any MCCCCX» (AHG, FN, Castelló, n⿳0 1850 , f.1 r.)

${ }^{30}$ Un dels casos que millor exemplifica aquest procediment és l'acord amb el creditor gironí Bernat Ferrer, ja que permet observar tots els passos que acabem de descriure. El 24 de febrer del 1414, aquest censalista certificava documentalment que el municipi li devia $39511.13 \mathrm{~s}^{2} \mathrm{~m}^{2}$ per les pensions endarrerides, des del mes de maig de 1398 , d'un censal mort de 2411 . 7 s. 7 d. anuals i un capital de 487 ll. 11 s. 8 d. (5\%). Tanmateix, el municipi presentà una àpoca en què el mateix Bernat Ferrer reconeixia haver cobrat, per mà del clavari Pere Caragol, $9711.10 \mathrm{~s} .4$ d. el dia 28 d'agost del 1406. A més, també s'acreditava que, segurament durant l'exercici 14081409 , Lleonard de Sos li havia lliurat unes altres 100 1l. Per tant, del muntant degut inicialment, s'havien de restar les quantitats que aquests dos administradors ja li havien pagat amb anterioritat: la universitat, doncs, finalment devia a Bernat Ferrer un total de 198 ll. $2 \mathrm{~s}$. $7 \mathrm{~d}$. ma . Ara bé aquesta quantia corresponia a pensions endarrerides que havien estat calculades a un interès del $5 \%$, així que el municipi -previ acord amb el creditor- les tornà a calcular a un 1,6\% d'interès, quedant definitivament reduît el deute a $66 \mathrm{ll}$. $10 \mathrm{~d}$. malla $\left(\mathrm{m}^{\mathrm{a}}\right)$. Finalment, el consistori es comprometia a lliurar aquesta quantitat en cinc anualitats: així, el 24 de febrer del 1414, Berna Ferrer cobrà 13 ll. $4 \mathrm{~s}$. 2 d., quantitat que rebria durant els següents quatre anys fins a saldar el ròssec: AHG, FN, Castelló, no 1945, f.106.
} 
continuat cobrant íntegrament llurs pensions fins el 1410. Pel que fa les primeres, el consistori no tindria excessives dificultats per assolir la reducció, atès que la majoria dels censals morts pertanyien a institucions de caràcter assistencial de la capital emporitana i, per tant, administrades o tutelades pel mateix govern castelloní ${ }^{31}$. Més complicat, en canvi, fou aconseguir l'acord amb els creditors religiosos que, en nom d'una determinada institució eclesiàstica, percebien la pensió d'un censal mort. En aquest sentit, els assentaments dels capbreus noticien dues llicències atorgades pel bisbe de Girona a la universitat de Castelló d'Empúries en què, molt probablement, s'autoritzava als religiosos de la seva diòcesi a rebaixar l'interès de les rendes $^{32}$. Malgrat que degueren contribuir a assolir la reducció d'interessos, aquestes llicències, però, no podien ser de cap manera vinculants i també calia comptar amb el consentiment del religiós que cobrava els diners de les pensions censals com a titular de la renda ${ }^{33}$.

Un cop analitzats els termes concrets dels acords, tot seguit delimitarem la cronologia d'aquest procés de sanejament del deute a partir de les dades que poden inferir-se dels capbreus. Per fer-ho, en la següent gràfica hem relacionat tots els pactes que s'assoliren amb els creditors segons la procedència geogràfica d'aquests. Igual que en l'apartat anterior, considerem que aquesta és la millor manera per il·lustrar la lògica del procés de reducció del deute $^{34}$.

\footnotetext{
${ }^{31}$ De fet, alguns dels procuradors d'aquestes institucions amb qui els cònsols van arribar a un acord, també van exercir altres càrrecs municipals. A tall d'exemple, el 15 d'abril del 1410, el clavari Joan Axerrat va cloure un pacte per disminuir el tipus d'interès de dos censals morts en poder de la Caritat de Cạstelló d'Empúries; un dels dos caritaters amb qui el signà fou Bartomeu Albert que, com hem vist, va ser el clavari de l'anualitat financera de 1405-1406: AHG, FN, Castelló, no 1850 , ff. 20 r.-22 v.

${ }^{32}$ Segons sembla, una d'aquestes provisions fou atorgada l'any 1410 , tal i com es pot inferir del pacte entre la universitat i la prioressa del monestir de Vall de Maria de Maçanet, que es segellà el 7 de desembre del 1419 (AHG , FN, Castelló, no 1945, f.168 r.). Com hem dít, però aquesta llicència no fou l'única concedida pel bisbe de Girona ja que, en el pacte del dia 11 de juliol del 1419 entre el clavari castelloní i els procuradors de l'Almoina del Pa de la Seu gironina se n'esmentava una altra, atorgada el 21 de febrer del 1411: AHG, FN, Castelló, n 1945 , f.165 r.

${ }^{33}$ Els paers de la vila de Cervera també yan obtenir llicències similars dels bisbes de Vic i d'Urgell des de, com a mínim, el 1411, tot i que això no significà que els creditors religiosos automàticament disminuïssin les pensions de llurs censals. De fet, molts anys després el consistori encara estava negociant amb alguns d'aquests la reducció d'interessos: P. VERDÉs, “Per ço que la vila no vage a perdició”, cit. p. 128.

${ }^{34} \mathrm{El}$ lector pot consultar la relació de tots els pactes obtinguts en el quadre $\mathrm{n}^{0} 2$ de l'apèndix d'aquest treball.
} 


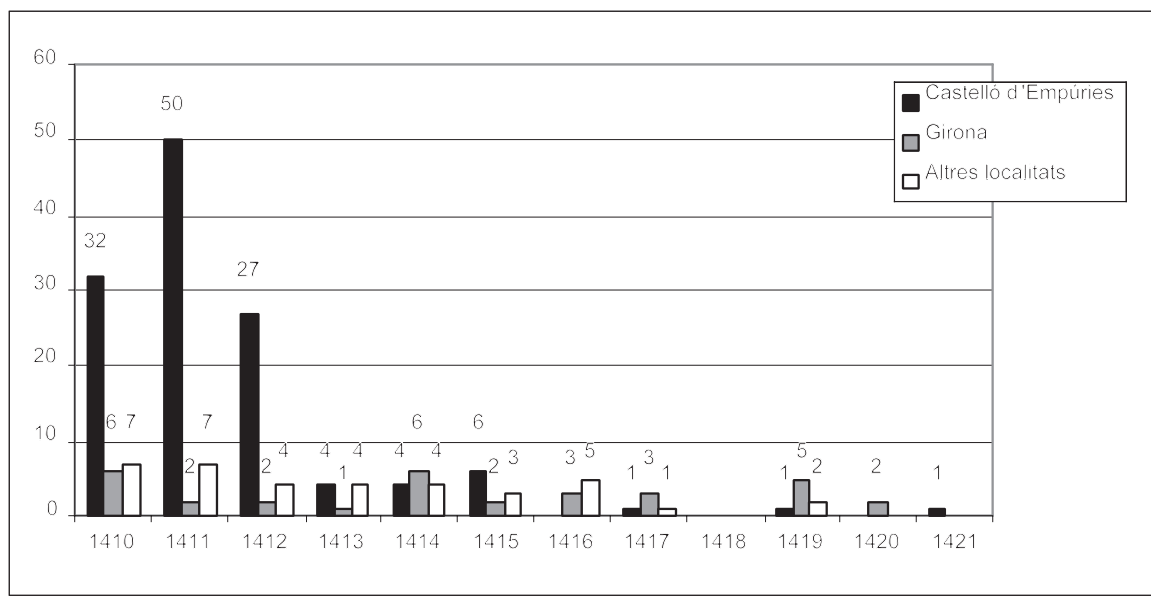

Gràfica $\mathrm{n}^{0} 3$ : Censals morts reduïts segons la procedència geogràfica dels seus propietaris (1410-1421)

Com pot veure's, durant aquest període el consistori va aconseguir reduir el tipus d'interès de 195 censals morts i, d'aquesta quantitat, 130 incloïen el pacte pel pagament de les pensions endarrerides; cosa que significa que aquestes rendes pertanyien a creditors laics, mentre que les restants 65 estaven en mans d'eclesiàstics (62) o d'institucions de caràcter assistencial (3). $\mathrm{Al}$ marge, però, d'aquesta consideració social - objecte d'estudi en la tercera part de l'article-, el que aquí voldríem assenyalar són les dues fases d'aquest complex procés de reducció general d'interessos: en una primera etapa, entre 1410 i 1412, s'assoliren el gruix dels acords (137), la gran majoria dels quals amb creditors locals (109); i, en una segona etapa, compresa entre 1413 i 1421, es produí una davallada considerable dels acords (58) que, com es pot observar, bàsicament s'obtingueren amb censalistes forans (42).

A l'hora d'interpretar aquestes dades, pensem que dos són els factors principals que ajuden a entendre la dinàmica de pactes amb els creditors castellonins, especialment important durant els primers anys d'aquest procés negociador. Primerament, la major sensibilitat d'aquest col-lectiu local davant les dificultats financeres de la pròpia vila: no podem oblidar que un elevat deute censal era sinònim d'un important augment de l'exigència fiscal sobre el conjunt de la població castellonina i, per tant, una davallada de les pensions censals podia servir per a pal-liar aquesta asfixiant pressió i, de retruc, també podia ajudar a reactivar l'economia local. I, en segon lloc, tampoc podem obviar que el govern municipal disposava de prou elements de "persuasió" que 
podien resultar molt efectius a l'hora d'obtenir la reducció de les pensions d'aquest grup 35 .

Pel que fa els creditors forans, cal imaginar que la lògica que seguí aquest procés de negociació no hauria tingut tant a veure amb els factors fins ara apuntats, atès que els vincles que els unien a la universitat castellonina no eren els mateixos que els dels creditors residents a la vila comtal. Conseqüentment, caldria identificar la capacitat de resistència dels censalistes forans davant la insolvència de la tresoreria castellonina com l'element clau a l'hora d'explicar la seva incorporació, més tard o més d'hora, en la dinàmica d'avinença amb el municipi. Així es podria entendre que els creditors gironins fossin, dins el col·lectiu forà, els que més reticències van mostrar a l'hora d'arribar a un acord amb els dirigents de Castelló d'Empúries: la majoria d'aquests censalistes eren membres d'acabalats llinatges patricis de la ciutat i, per tant, podien resistir més temps enfront de l'impagament de llurs censals morts que els creditors més modestos d'altres poblacions. A més, no hem d'oblidar tampoc la centralitat econòmica i financera adquirida per Girona al llarg del s. XIV, que posava a l'abast dels creditors d'aquesta ciutat mecanismes molt efectius a l'hora de forçar les autoritats castellonines a complir les obligacions creditícies contretes, tal i com hem vist en la carta de la reina Maria del $1396^{36}$. Finalment, si tenim en compte l'elevada inversió en deute públic castelloní realitzada per aquests individus, resulta perfectament comprensible la seva actitud reticent envers la política de negociació amb el municipi: els censalistes gironins deurien percebre aquest procés, més que cap altre col·lectiu, com una renúncia -alguns d'ells, per segona vegada des del 1386- a uns beneficis que legítimament els pertocaven, ja fos acceptant una minva sensible de les seves rendes anuals o, potser més important encara, desistint de cobrar una part important de les pensions endarrerides des de feia uns quants anys.

Ara bé, recordem que la suspensió de pagaments fou utilitzada pel govern castelloní com una mesura de força per a compel·lir als creditors a acceptar una rebaixa d'interessos i, per tant, l'enrocament davant la negociació els podia exposar a no rebre cap altra pensió de forma indefinida ${ }^{37}$. Aquesta

\footnotetext{
${ }^{35}$ Tal com s'observa en altres indrets, les autoritats locals podien incentivar la rebaixa d'interessos de les rendes oferint als creditors locals certes contrapartides, com ara, l'exempció de determinats impostos; o, per contra, també podien mostrar la seva faceta més coercitiva, tot advertint al censalista que, si no accedia a reduir la seva renda, deixaria de percebre-la. Aquest tipus d'estratègies es constaten, per exemple, a Valls i Cervera: J. MORELLÓ, Fiscalitat $i$ deute públic, cit. p.806; P. VERDÉS, "Per ço que la vila no vage a perdició", cit. p.103.

${ }^{36}$ Una actitud similar mostraren els creditors de la ciutat de Barcelọna, la presència dels quals era realment significativa dins el deute censal de molts indrets del principat 1 , fins i tot, en altres territoris de la Corona d'Aragó; vegeu les formes de represàlia emprades per aquest col-lectiu davant la insolvència de les corporacions municipals a P. VERDÉS, Barcelona, capital del mercat del deute públic català, segles XIV-XV, dins M. SÁNCHEZ (coord.), El món del crèdit a la Barcelona Medieval [= "Barcelona Quaderns d'Història", 13 (2007), p.291].

${ }^{37}$ Tot i que per la seva llunyania cronològica no els hem inclòs en la gràfica $n^{\circ} 4$, els millors exemples es poden observar en els quatre últims assentaments del segon capbreu, que es refereixen a sengles pactes obtinguts amb creditors entre 1437 i 1441 . Un d'aquests acords es formalitzà el 29 de desembre del 1437 amb els procuradors de l'obra de Santa Maria de Castelló d'Empúries per un censal mort que portava suspès des del 1380, la qual cosa significa que els propietaris anteriors d'aquesta renda s'havien negat a acceptar la reducció del seu tipus d'interès
} 
possibilitat i, probablement, els exigus resultats de les accions legals empreses contra la universitat, van acabar per obligar també als creditors de Girona a acceptar un acord amb el consistori de Castelló d'Empúries.

\subsection{El resultat de la política de reducció del deute (1421)}

Més enllà de la major o menor resistència dels censalistes, el fet és que arribats a 1421 la pràctica totalitat dels pactes amb el consistori castelloní ja s'havien produït, per la qual cosa podem assenyalar aquesta data com el final del procés de sanejament del deute municipal. Tenint en compte, tal com dèiem en la primera part, que els capbreus de censals es van concebre com un gran inventari de totes les rendes que la universitat estava obligada a pagar, a partir de les dades que ens proporcionen aquests registres podem fer-nos una idea força fiable de quines eren les xifres globals de l'endeutament de Castelló d'Empúries aquell any.

Quadre $\mathrm{n}^{\mathrm{0}} 1$ : El deute de Castelló d'Empúries l'any 1421

\begin{tabular}{|c|c|c|c|}
\hline & $\mathbf{N}^{\mathbf{o}}$ & Capital & Pensions \\
\hline Censals morts $(7,14 \%)$ & 1 & $11511.10 \mathrm{~s}$. & 8 11. 5 s.(1) \\
\hline Censals morts $(5 \%)$ & 3 & $1.45811 .16 \mathrm{~s}$. & 73 11. 1 s. 6 d.(2) \\
\hline Censals morts $(3,3 \%)$ & 2 & 111 1l. 7 s. 8 d. & 411.7 s. $7 \mathrm{~d} . \mathrm{m}^{\mathrm{a}}$ \\
\hline Censals morts $(2,5 \%)$ & 197 & 42.568 ll. 8 s. $10 \mathrm{~d}$. & $1.05611 .18 \mathrm{~s} .8 \mathrm{~d}$. \\
\hline Censals perpetuals $(3,3 \%)$ & 52 & 7.435 11. 7 s. $10 \mathrm{~d}$. & 245 11. 2 s. $5 \mathrm{~d} . \mathrm{m}^{\mathrm{a}}$ \\
\hline Censals perpetuals $(2,5 \%)$ & 4 & 59311. & 14 1l. $16 \mathrm{~s} .6 \mathrm{~d}$. \\
\hline Total & 259 & 52.282 ll. 10 s. 4 d. & 1.402 ll. 11 s. $9 d$. \\
\hline
\end{tabular}

(1) La pensió d'aquest censal mort estava suspesa el 1421.

(2) Les pensions d'aquests tres censals morts estaven suspeses el 1421

A la llum d'aquestes xifres, el primer que volem posar de relleu és que, malgrat l'abast del procés de sanejament del deute dut a terme pel govern municipal, que obtingué la reducció del tipus d'interès de 195 censals morts, no totes les rendes de la universitat van veure minvada llur pensió. Bàsicament, ens referim als nombrosos censals perpetuals que ni els havia afectat la suspensió de pagaments, ni havien estat objecte de cap acord per la rebaixa del seu tipus d'interès. Per tant, a l'hora d'intentar establir el deute total de

per espai de 57 anys (vegeu la relació d'aquests quatre acords en el quadre $\mathrm{n}^{0} 2$ de l'apèndix). 
Castelló d'Empúries l'any 1421, també hem inclòs, lògicament, totes aquestes rendes irredimibles ${ }^{38}$.

Dit això, la segona qüestió que ens interessa remarcar és la de l'evolució respecte a la situació observada el 1393, l'any en què finalitzà el primer procés de sanejament del deute ${ }^{39}$. Així, per exemple, el nombre de rendes que la tresoreria satisfeia aquell any (216) era inferior al de 1421 que, com acabem de veure, havia augmentat fins a les 259. Cal dir, però, que aquestes 43 noves rendes no van ser el resultat de l'emissió de més deute municipal, sinó de la fragmentació al llarg dels anys d'alguns dels censals morts documentats el 1393.

Així mateix, continuant amb la comparació, cal subratllar la davallada del capital degut: mentre que el 1393 Castelló d'Empúries devia 58.824 11. 16 s. 6 d., al cap de 28 anys aquesta quantitat havia disminuit fins a les $\mathbf{5 2 . 2 8 2}$ 11. 10 s. 4 d., això és, una minva de $6.54211 .6 \mathrm{~s} .2$ d. ${ }^{40}$. L'explicació més plausible d'aquesta disminució rau en una hipotètica política de redempció de rendes realitzada pel municipi durant aquests anys i, en aquest sentit, els capbreus constaten, efectivament, la lluïció d'alguns censals morts ${ }^{41}$. Tanmateix, la suma de totes les operacions de rescat ascendeix a 2.886 11. 6 s., força lluny de les 6.542 ll. 6 s. 2 d. de diferència existent entre 1393 i 1421. A l'espera d'una futura recerca documental que ho pugui confirmar, ara com ara només podem especular que les 3.656 ll. 2 d. restants degueren respondre igualment a més amortitzacions de censals.

Per últim, la darrera diferència que s'observa entre 1393 i 1421 és la important reducció del volum total de les pensions censals, que passen de les 2.948 ll. 4 s. 5 d. ma a les 1.402 ll. 11 s. 9 d. anuals. De fet, aquesta disminució era l'objectiu principal de la política de sanejament del deute endegada pel govern castelloní el 1410 i, òbviament, fou el resultat de la rebaixa pactada dels interessos dels censals morts. L'any 1421 el tipus d'interès mitjà de les rendes de Castelló d'Empúries s'havia reduït fins el $2,71 \%$, gairebé la meitat del que podia documentar-se el 1393 (4,98\%). Aquesta tendència a la baixa dels interessos no era cap excepció dins el context

\footnotetext{
${ }^{38} \mathrm{~A}$ més, també hem cregut convenient comptabilitzar els esmentats quatre censals morts que, per culpa de la resistència dels seus propietaris, el municipi no aconseguí la rebaixa de llurs interessos fins els anys 1437 i 1441 (vegeu la nota 37).

${ }^{39}$ A. MARTí ARAU, Endeutament censal, p.186.

${ }^{40}$ Lògicament, el capital degut per Castelló d'Empúries es trobava lluny del de la ciutat de Barcelona que, a principis del s. XV ratllava les 390.000 ll., però eren bastant properes a les xifres de la vila de Cervera el 1413 (65.000 11.) i molt superiors a les de Valls el mateix any 1421 (22.177 11.): Pere ORTÍ, Les finances municipals de la Barcelona dels segles XIV $i$ XV: del censal a la Taula de Canvi, dins M. SÁNCHEZ, El món del crèdit, p. 271; P. VERDÉS, "Per ço que la vila no vage a perdició", cit. p.316; J. MORELló, Fiscalitat $i$ deute públic, cit. p.892.

${ }^{41}$ A més dels ćapbreus, el llevador de censals de 1417-1418 i el "manual de reduccions" de 1386-1387 també ens han proporcionat notícies sobre redempcions de rendes: AHG, FN,

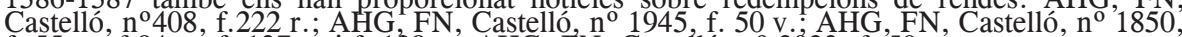
f. 55 v., f. 94 r., f. 127 v. i f. 129 r.; AHG, FN, Castelló, no 2023, f. 50 v'.
} 
general de Catalunya, tot i que la xifra que presenta la capital emporitana es compta entre les més baixes del principat per aquest període ${ }^{42}$.

\section{ELS CREDITORS DE CASTELLÓ D’EMPÚRIES}

Una vegada descrita la complicada gestió de l'endeutament municipal a Castelló d'Empúries entre 1386 i 1421, ara és moment d'endinsar-nos en el món dels propietaris de rendes durant el mateix període. Concretament, l'objectiu d'aquesta tercera i última part és aprofundir en tres qüestions fonamentals a partir de l'exemple estudiat: la condició social dels creditors, la seva procedència geogràfica i l'anomenat mercat secundari del deute.

D'entrada, dibuixarem la geografia del deute el 1421 i la compararem amb l'observada el 1393, un cop hagué acabat el primer procés de sanejament financer. Com veurem, malgrat existir algunes diferències entre un i altre any, el que podrem constatar sobretot és una de les particularitats del deute públic de Castelló d'Empúries durant tot aquest període, ja apuntada en pàgines precedents: la importància dels censalistes de Girona dins l'endeutament municipal. Tot seguit, aprofitant la informació genealògica que ens ofereixen els capbreus sobre la "vida" dels censals, abordarem la qüestió del mercat secundari del deute, això és, la transacció de rendes durant el període que va des de 1386, moment en què s'inicià el primer procés de reducció del deute, fins a 1421, any en què finalitzà el segon. El propòsit principal d'aquest apartat serà determinar fins a quin punt la crisi financera experimentada per la tresoreria castellonina durant aquest període condicionà la transmissió de les rendes o, més concretament, si aquestes dificultats van modificar d'alguna manera la funció que els creditors conferiren a llurs censals en el decurs dels anys. Finalment, en el tercer apartat descriurem els canvis que s'observen en la condició social dels censalistes entre 1393 i 1421. Com veurem, la importància dels creditors gironins dins l'endeutament municipal, així com la dinàmica del mercat secundari del deute, ajudaran a comprendre no només els criteris escollits a l'hora de classificar els propietaris de rendes, sinó també el pes específic de cadascun d'aquests grups socials dins el conjunt dels censalistes.

\subsection{La geografia del deute (1421)}

Pel que fa la geografia del deute, i d'igual manera que en altres ocasions, hem classificat els creditors de Castelló d'Empúries en tres grups,

\footnotetext{
${ }^{42}$ Un cas molt similar al de Castelló d'Empúries fou el de Valls que, per tal de superar una fallida financera decretada el 1406, el consistori obtingué acords amb els creditors per a la rebaixa dels censals fins a un 2,5\% d'interès $i$, en alguns casos, a un $2 \%, 1,6 \%$ o 1,25\%: J. MORELLÓ, Fiscalitat $i$ deute públic, p.890. Així mateix també sabem -per referències indirecteses- que les poblacions de Montblanc o Santa Coloma de Queralt van aconseguir una disminució d'interessos dels censals fins a un $2,5 \%$ a principis del $\mathrm{s}$. XV: Cf. P. VERDES, "Per ço que la vila no vage a perdició", cit. pp.126-130.
} 
en funció de si procedien de la mateixa capital comtal, de Girona o bé d'altres poblacions.

Quadre n²2: El deute públic de Castelló d'Empúries l'any 1421, segons la procedència geogràfica dels creditors.

\begin{tabular}{|c|c|c|c|}
\hline & Creditors & Capital & Pensions \\
\hline Castelló & 46 & 27.683 11. 12 s. 11 d.m ${ }^{a}$ & 738 11. 15 s. $5 \mathrm{~d}$. \\
\hline Girona & 21 & 12.854 ll. $3 \mathrm{~s} .1 \mathrm{~d}$. & 34211. \\
\hline Altres & 46 & 11.555 11. 14 s. 3 d.m ${ }^{a}$ & $11 \mathrm{~d} \cdot \mathrm{m}^{\mathrm{a}}$ \\
\hline Total & 113 & 52.093 ll 10 s. $4 \mathrm{~d}$. & 1.398 1l. 17 s. 10 d. $\mathrm{m}^{\mathrm{a}}(3)$ \\
\hline
\end{tabular}

(3) La diferència que resta per a completar les quantitats totals que assenyalàvem en el quadre $\mathrm{n}^{\mathrm{o}} 1$ és deguda a la impossibilitat d'ubicar el lloc de procedència d'un creditor.

I per veure millor el pes de cadascun d'aquests tres grups, també hem convertit les xifres del quadre en percentatges, bo i comparant-los amb els que tenim per l'any 1393 a fi de comprovar si es produí alguna diferència significativa entre els dos anys.

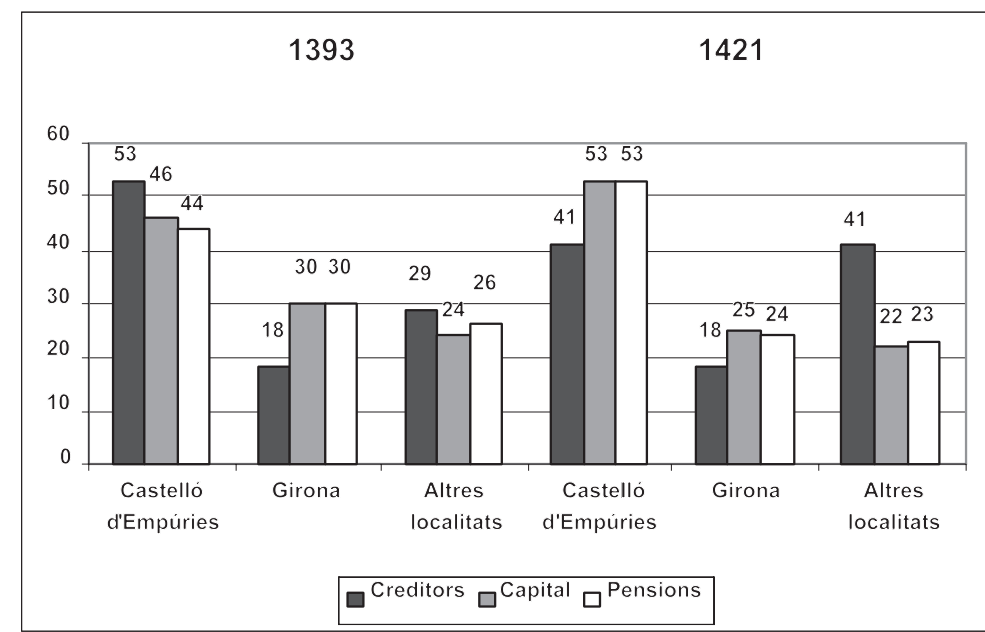

Gràfica nº 4: La geografia del deute a Castelló d’Empúries els anys 1393 i 1421 en percentatges. 
Si tan sols ens fixem en els creditors procedents de Castelló d'Empúries, ens adonarem d'un canvi fonamental en relació a l'any 1393. Llavors, el nombre d'aquests censalistes constituïa un 53\% del total, però només eren propietaris d'un $46 \%$ del capital degut per la universitat i, en funció de l'interès de llurs rendes, ingressaven un $44 \%$ del volum de les pensions censals. Dit d'una altra manera: per bé que numèricament els creditors locals eren majoria, més de la meitat dels interessos del deute que pagava la seva pròpia vila era drenada per creditors forans. Tal i com podem veure en la gràfica, 28 anys després aquesta relació s'havia invertit: si bé els censalistes castellonins representaven menys de la meitat del total $(41 \%)$, aquests cobraven un 53\% de les pagues censals. Ara com ara, no podem determinar les causes concretes d'aquest canvi de papers però, a la llum del que succeeix en altres poblacions, és probable que el govern municipal prioritzés la redempció de les rendes en mans dels creditors forans, normalment menys sensibles que els locals davant les mostres d'insolvència del municipi ${ }^{43}$.

En referència als creditors forans, si deixem al marge la ciutat de Girona, en el mapa $n^{0} 1$ de l'apèndix s'observa la presència d'un elevat nombre de creditors procedents de la rodalia de Castelló d'Empúries, malgrat que el seu pes específic és força relatiu. Aquests censalistes es trobaven disseminats per 34 localitats, la gran majoria de les quals incloses dins el radi d'influència de la vila emporitana. D'entre aquests creditors, destaquen els de Figueres, que cobraven el 2,37\% de les pensions anuals, així com els de Peralada $(2,1 \%)$, Palau de Santa Eulàlia $(1,57 \%)$, Riumors $(1,43 \%)$, la Tallada $(1,29 \%)$ i Fortianell $(1,12 \%)^{44}$.

Finalment, els creditors de Girona percebien el $25 \%$ dels interessos anuals, la qual cosa demostra, novament, que aquesta ciutat exercia, en el cas de Castelló d'Empúries, una capitalitat financera similar a la que Barcelona exercí dins el deute públic d'altres poblacions de la Corona d'Aragó ${ }^{45}$. A més, i a jutjar pels resultats reflectits a la gràfica anterior, el col·lectiu gironí fins i tot experimenta un relatiu increment entre nombre de creditors i les altres dues variables, justament la dinàmica contrària a la de la resta de censalistes forans. Com hem vist, el 1393, aquesta tendència s'havia manifestat ja, i aleshores l'explicàvem a partir de dos factors: d'una banda, per la rellevància de bona part dels censals que posseïen els gironins, els preus dels quals eren

\footnotetext{
${ }^{43}$ No endebades, la major part del capital lluït pel consistori castelloní entre 1393 i 1421 pertanyia a creditors forans (2.105 11.). Vegeu també exemples de polítiques encaminades cap al mateix objectiu a Cervera, Manresa, Reus o Cardona: M. TURULL, La configuració jurídica del municipi baix.medieval, Barcelona, Fundació Noguera, 1990, pp.485-486; Marc TORRAS, El deute públic a la ciutat de Manresa a la Baixa Edat Mitjana dins M. SÁNCHEZ (ed.), Fiscalidad real y finanzas urbanas, cit. p.181; J. MORELLO, Fiscalitat $i$ deute públic, cit. p.786; A. GALERA, Endeutament i fiscalitat senyorial, p.419.

${ }^{44}$ Aquestes poblacions també s'inclouen en l'esfera comercial de Castelló d'Empúries que traçà Anthony Pinto pel que fa la indústria tèxtil: A. PINTO, Commerce et draperie, vol.II, pp.419-434.

${ }^{45}$ Els censalistes residents a la ciutat de Barcelona tenien, certament, un paper testimonial dins el deute públic de la vila comtal, atès que tan sols cobraven un $3,55 \%$ del total de les pensions censals; molt lluny, doncs, de l'enorme pes dels creditors de Girona.
} 
de mitjana força més elevats que els de la resta de creditor $^{46}$; i, d'altra banda, perquè llurs rendes gaudien del tipus d'interès més alt que pagava llavors el municipi (censals morts al 5\%). Dit en altres paraules, els censalistes gironins comptaven amb pocs efectius, però el volum i l'interès de les rendes que tenien feien augmentar el seu pes específic dins el deute públic de Castelló d'Empúries. Doncs bé, prop de tres dècades després, la importància dels censalistes gironins continuava sent considerable malgrat la reducció d'interessos, i això degut a la importància que continuava tenint el capital de llurs censals: la seva mitjana era de 430 ll., netament superior a la dels altres creditors forans (190 11.), i també a la dels locals (160 ll.).

\subsection{El mercat secundari del deute}

Els dos capbreus castellonins documenten fins a 336 transmissions de censals entre 1386 i 1421, efectuades de diverses formes. Lògicament, si tenim en compte l'amplitud de l'arc cronològic, molts dels canvis de propietat de les rendes es degueren a donacions mortis causa (155), tot i que també se'n realitzaren en vida del creditor (87). En principi, aquestes 242 donacions de censals confirmarien la tesi clàssica segons la qual el deute públic només serví per estimular l'esperit rendista dels sectors socials que hi invertiren, ja que deixen entreveure el desig del censalista a l'hora de garantir-se la percepció d'una pensió anual fins el dia de la seva mort o, en cas de voler transmetre-la en vida, d'assegurar un ingrés a una altra persona - gairebé sempre un familiar-o a una institució religiosa o benèfica ${ }^{47}$. Ara bé, els memorials també documenten unes altres 94 transmissions de censals que no són designades com a donacions, sinó que la gran majoria són qualificades com a operacions de compravenda $(78)^{48}$.

Segons el nostre parer, aquestes transaccions es produïren amb una intenció completament diferent a la de les donacions, atès que mostrarien l'ús del censal com una forma d'inversió que, a més de generar uns determinats

\footnotetext{
${ }^{46}$ El 1393 la mitjana del capital dels censals posseïts pels creditors de Girona era de 550 11.. En canvi, la dels altres censalistes forans estava a l'entorn de les 29011 ., mentre que la dels castellonins rondava les 220 ll. : A. MARTí ARAU, Endeutament censal, p.192.

${ }^{47} \mathrm{Com}$ és sabut, tradicionalment s'havia posat l'accent en què l'emissió de deute incentivà sobretot aquesta actitud en els sectors econòmicament més emprenedors de la societat -llegiu mercaders- que, en comptes d'invertir els seus capitals en arriscades - però més productivesoperacions comercials, preferiren immobilitzar-los en la compra segura de rendes perpètues vitalícies. Vegeu, per exemple, les obres clàssiques de Jaume VICENS VIVES, Evolucion de la economía catalana durante la primera mitad del siglo XV dins "IV Congrés d'Història de la Corona d'Aragó", Palma de Mallorca, Diputación Provincial de Baleares, 1955, pp.20-21; Pierre VILAR, Catalunya dins l'Espanya moderna: recerques sobre els fonaments economics de les estructures nacionals, vol.I, Barcelona, Edicions 62, 1986, pp.216-219; Ramon D'ABADAL, Pere el Cerimoniós $i$ els inicis de la decadència política de Catalunya, Barcelona, Edicions 62, 1972, pp.52-53; Claude CARRËE, Barcelona 1380-1462, un centre economic en època de crisi, vol. 1, Barcelona, Curial, 1977, pp.177-178.

${ }^{48} \mathrm{Al}$ marge de les vendes, en els capbreus figuren un petit grup de 16 operacions, la naturalesa de les quals no s'especifica clarament, perồ que deixen ẹtreveure algun tipus de contraprestació econòmica (penyores, permutes, retribucions de serveis, etc.) Obviament, a fi de conèixer la naturalesa exacta d'aquestes transaccions, així com de la resta, caldria localitzar el document complet ressenyat en el capbreu; tasca que deixem per a un futur estudi.
} 
interessos cada any, era suficientment atractiva com per poder trobar un comprador en el mercat secundari del deute que permetés al propietari de la renda, si així ho desitjava o bé ho necessitava, recuperar la quantitat que n'havia pagat temps enrere; operacions que ens allunyarien de la visió del censal com un simple instrument creditici d'immobilització de capitals. Per aquest motiu, en el quadre que segueix sobre la transmissió de rendes a Castelló, hem considerat convenient realitzar una distinció bàsica segons si la cessió de la propietat s'efectuà amb o sense ànim de lucre, és a dir, si es van formalitzar en escriptures de venda o bé en forma de donacions ${ }^{49}$. Així mateix, també hem volgut classificar-les en funció de la condició social (laica o eclesiàstica) del creditor que traspassava la renda i d'aquell que la rebia, atès que il·lustra encara més la lògica d'aquesta dinàmica.

Quadre n³: Transmissió de censals a Castelló d'Empúries $(1386-1421)$

\begin{tabular}{|c|l|l|l|l|l|}
\hline $\begin{array}{l}\text { Transaccions amb ànim de } \\
\text { lucre }\end{array}$ & $\mathbf{N}^{\mathbf{0}}$ & Venedors & $\mathbf{N}^{\mathbf{0}}$ & Compradors & $\mathbf{N}^{\mathbf{0}}$ \\
\hline Vendes (4) & 94 & Laics & 94 & Laics & 79 \\
\hline $\begin{array}{l}\text { Transaccions sense ànim de } \\
\text { lucre }\end{array}$ & & Donadors & & Receptors & 15 \\
\hline Donacions & 242 & Laics & 240 & Laics (familiars) & 158 \\
\hline & & Eclesiàstics & 2 & Eclesiàstics & 84 \\
\hline Total & $\mathbf{3 3 6}$ & & & & \\
\hline
\end{tabular}

(4) A fi i efecte de facilitar la comprensió d'aquest quadre, aquest número també inclou les 16 operacions que no són designades explícitament com a compravendes però que trasllueixen una intenció lucrativa (vegeu la nota 48).

Com ja hem avançat, entre 1386 i 1421 , les rendes municipals eren sobretot transmeses per mitjà de donacions a familiars dels creditors $(158)^{50}$.

\footnotetext{
${ }^{49} \mathrm{Pel}$ cas de Cervera, Pere Verdés ja distingeix entre aquells creditors que invertiren en deute públic amb finalitats lucratives o rendistes: P. VERDES, "Per tal que no calgués a logre manlevar", p.50). Així mateix Juan Vicente García Marsilla assenyala que més de la meitat dels censals emesos per la ciutat de València a finals del s. XIV no duraven més d'una dècada en mans dels compradors originals, ja que en el transcurs d'aquest període eren adquirits per tercers en el mercat secundari del deute: "De ello se deduce que para algunos la adquisición de deuda municipal tenía un fuerte componente especulativo: se podian cobrar los seguros intereses durante unos anos, y en cuando fuera necesario se podía «rescatar» el capital fácilmente poniendo a la venta el censal, que otros muchos estaban deseando poseer» (J.V. GARCÍA MARSILLA, Vivir a crédito en la Valencia medieval. De los orígenes del sistema censal al endeudamiento del municipio, València, Universitat de València, 2002, p.277).

${ }^{50} \mathrm{D}$ 'aquest total, en 16 ocasions no hem pogut determinar el vincle familiar exacte entre el donador i el receptor.
} 
En concret, la majoria de donacions - especialment les mortis causa- foren de pares a fills (88), tot i que també anaren cap a altres membres de la família del censalista: a un germà (26 ocasions), a algun dels seus pares (10), a un nét (4), a la seva muller vídua o marit vidu (4), a un nebot (2), a algun dels seus sogres (2), a una cunyada (2), i a un gendre, a una madrastra, a un oncle o bé a un cosí germà ${ }^{51}$. Tot i així, també pot veure's com un nombre considerable de les donacions realitzades per creditors laics van anar cap a l'estament eclesiàstic. Malgrat que en el següent apartat aprofundirem en aquesta qüestió, aquí ja podem avançar que es tractava d'institucions caritatives i, sobretot, comunitats religioses a qui la majoria de les vegades el censalista traspassava la renda pel manteniment d'un benefici destinat a la salvació de la seva ànima $^{52}$.

Com hem dit, a la llum d'aquestes dades, hom podria estar temptat d'afirmar que la lògica predominant a l'hora d'invertir en deute municipal fou essencialment rendista. Tanmateix, el quadre anterior demostra que, al marge de les donacions, també s'efectuaren un nombre significatiu d'operacions de compravenda, la qual cosa evidencia l'existència d'un mercadeig relativament actiu de rendes $i$, per tant, una transferència prou important de capitals entre particulars.

Ara bé, més enllà de constatar l'existència d'un nombre considerable de compravendes, no podem obviar tampoc - encara que pugui resultar evident- que la política financera de les autoritats municipals de Castelló d'Empúries durant aquest període degué repercutir de forma transcendental en la lògica del mercat secundari del deute. En aquest sentit, i malgrat que no disposem de dades anteriors a 1386, quan el municipi pagava normalment les pensions, sí que podem observar el que va succeir abans i després de 1400, això és, l'any en què la segona suspensió de pagaments es féu del tot evident a ulls dels censalistes. Tenint en compte aquesta data, hem establert una distinció cronològica pel que fa les transmissions de censals contingudes en el quadre anterior, a fi i efecte de determinar fins a quin punt la crisi de la tresoreria municipal va condicionar el mercat secundari del deute.

\footnotetext{
${ }^{51}$ És interessant assenyalar que, del totạl de donacions inter vivos (87), una part significativa van ser propter nupcias, és a dir, transaccions en què s'incloïa el censal o una part d'aquest (en tots els casos documentats un censal mort) en el dot de la filla (16), germana (3) o néta (1) del creditor en el moment de contraure matrimoni. En aquest sentit, cal dir també que les mencionades donacions a una madrastra, una cunyada i a dos sogres del censalista es van produir en tant que restitucions del dot.

${ }^{52}$ Sobre la generalització del censal mort, des de mitjan del s. XIV, com a mecanisme privilegiat de finançament de les misses aniversari del difunt, vegeu: Mercè ẢvENTÍN, Mercat de rendes, mercat de salvació, dins M. SÁNCHEZ, Estudios sobre renta, fiscalidad y finanzas en la Cataluña bajomedieval, CŚIC, Barcelona, 1993, pp.139-151. Pel que fa específicament el deute públic, sabem que a la Barcelona del s. XIV els censals i violaris emesos per les corporacions municipals es convertiren, mica en mica, en lẹs formes més utilitzades pel manteniment dels beneficis religiosos fundats en diverses institucions eclesiàstiques de la ciutat: Cristina BORAU, Els promotors de capelles $i$ retaules a la Barcelona del s.XIV, Barcelona, Fundació Noguera, 2003, pp. 259-281.
} 
Quadre $\mathrm{n}^{\mathrm{0}} 4$ : Cronologia de les transmissions de censals (1386-1421)

\begin{tabular}{|c|c|c|c|c|}
\hline & $\mathbf{1 3 8 6 - 1 4 0 0}$ & $\mathbf{\%}$ & $\mathbf{1 4 0 1 - 1 4 2 1}$ & $\mathbf{\%}$ \\
\hline $\begin{array}{l}\text { Transaccions amb ànim de } \\
\text { lucre }\end{array}$ & & & & \\
\hline \multicolumn{1}{|c|}{ Vendes } & 77 & 34 & 17 & 15 \\
\hline $\begin{array}{l}\text { Transaccions sense ànim de } \\
\text { lucre }\end{array}$ & & & & \\
\hline \multicolumn{1}{|c|}{ Donacions } & 147 & 66 & 95 & 85 \\
\hline Total & $\mathbf{2 2 4}$ & $\mathbf{1 0 0}$ & $\mathbf{1 1 2}$ & $\mathbf{1 0 0}$ \\
\hline
\end{tabular}

Com es pot comprovar, malgrat no ser la forma de transmissió predominant, la venda de censals encara fou relativament freqüent durant l'etapa 1386-1400, mentre que en la següent — tot i abastar més anys- el nombre d'aquest tipus d'operacions decau sensiblement. Possiblement, aquesta tendència només es pot explicar pels efectes positius que va tenir el procés de reducció del 1386-1393 que, a més de significar un alleujament del feixuc pes del deute, també degué servir per restaurar la confiança dels creditors en els censals com a producte especulatiu. Altrament dit, els censalistes sabien que podien acudir al mercat secundari del deute amb la certesa de què hi trobarien persones o institucions interessades en comprar les seves rendes, especialment els censals morts que, malgrat haver vist reduït el seu tipus d'interès mitjà fins a un $5 \%$, continuava proporcionant un considerable guany econòmic ${ }^{53}$. En un moment, doncs, en què el censals havien recuperat el seu caràcter negociable, força creditors optaren per vendre llurs rendes i, d'aquesta manera, recuperaren el capital que hi havien invertit temps enrere ${ }^{54}$.

En canvi, una vegada la segona suspensió de pagaments es generalitzà (1401-1410), resulta comprensible que es constati una davallada de les compravendes de censals, atès que la manifesta insolvència de la hisenda municipal provocà que els potencials compradors de rendes deixessin de

\footnotetext{
${ }^{53}$ De fet, 81 de les 94 operacions amb ànim de lucre tingueren com objecte de transacció un censal mort, mentre que només en 13 ocasions fou un censal perpetual.

${ }^{54}$ Evidentment, els creditors que acudien al mercat secundari del deute per vendre-hi censals no sempre họ devien fer per voluntat pròpia, sinó obligats per les circumstàncies. Així es desprèn de l'operació de venda d'un censal mort formalitzada entre el prevere castelloní, Pere Gibern, i el jurista de Girona, Pere Moles. Segons els capbreus, aquest ultim comprà un censal mort de 6 11. 15 s. 9 d. anuals (5\%) al religiós el 16 d'abril del 1388. Tanmateix, Pere Moles no pagà el preu teò̀ric de la renda (135 ll. $15 \mathrm{~s}$.), sinó que només abonà 95 ll. $6 \mathrm{~d}$., és a dir, talment cọm sị s'hagués calculat la pensió a un interés del 7,14\%. D'aquesta manera, el guany pel nou propietari es fa evident: segurament aprofitant un moment d'urgència econòmica de Pere Gibern, Moles aconseguí adquirir ú renda per un "preu" inferior al que pertocava. Per tant, a més d'obtenir la pensió anual, també s'assegurava, en cas que vengués la renda a un tercer o de què el consistori castelloní redimís el censalmort, les 135 ll. 15 s. del capital "real", això és, un guany de 4011. 14 s. 6 d.: AHG, FN, Castelló, no 1945 , ff.9 v.-10 v.
} 
contemplar-les com una bona inversió. Segurament, aquesta percepció no va canviar gaire amb el restabliment de les pensions entre 1410 i 1421, ja que la nova reducció d'interessos (2,5\% pels censals morts i 3,3\% pels perpetuals) acabà convertint els censals castellonins en una forma de crèdit amb un rendiment força exigu en comparació a d'altres oportunitats d'inversió. Molt probablement, doncs, la desconfiança i l'escassa perspectiva de guany degueren provocar la contracció del mercat secundari del deute municipal des de principis del s. XV. A partir de llavors, predominaren les donacions a familiars i, com ja hem vist, també es produí un incessant degoteig cap a institucions religioses o assistencials.

\subsection{El perfil social dels creditors (1421)}

Així doncs, tenint en compte la dinàmica del mercat secundari del deute, considerem que es poden entendre més fàcilment els canvis en la composició social dels creditors de Castelló d'Empúries ocorreguts entre 1393 i 1421, és a dir, entre la fi del primer i del segon procés sanejament de la tresoreria municipal. En efecte, la minva del caràcter lucratiu dels censals, resultat de la crisi financera de la hisenda local, va comportar que, amb el pas del temps, determinats grups socials que podríem qualificar de rendistes esdevinguessin predominants dins el conjunt dels censalistes, és a dir, persones o institucions que valoraven la renda censal com una font d'ingressos indefinida, i no tant com un instrument susceptible de ser venut en el mercat secundari del deute. A la llum dels següents quadres, es pot veure quins són aquests col·lectius que guanyaren protagonisme dins l'endeutament de la vila comtal, així com aquells que, en contrapartida, perderen importància.

Quadre n5: El perfil social dels creditors l'any 1393

\begin{tabular}{|c|c|c|c|c|c|}
\hline & Grups socials & Capital & $\%$ & Pensions & $\%$ \\
\hline \multirow[t]{8}{*}{ Laics } & Ciutadans (Girona) & 10.686 1l. 1 s. 4 d. & 18,17 & 490 1l. 8 s. 1 d. & 16,8 \\
\hline & Dones & $7.67111 .8 \mathrm{~s} .4 \mathrm{~d}$. & 13,04 & 390 11. 7 s. 5 d. & 13,22 \\
\hline & Noblesa & $5.58611 .8 \mathrm{~s} .7 \mathrm{~d}$. & 9,5 & 335 11. 7 s. 8 d. & 11,36 \\
\hline & Juristes & $6.56811 .1 \mathrm{~s} .1 \mathrm{~d}$. & 11,17 & $30711.2 \mathrm{~s} . \quad \mathrm{m}^{\mathrm{a}}$ & 10,41 \\
\hline & Mercaders & $5.361 \mathrm{ll} 4 \mathrm{~s} .5 \mathrm{~d}$ & 9,11 & 283 1l. 5 s. 1 d. & 9,59 \\
\hline & Indústria tèxtil & 2.01811 .2 s. $3 \mathrm{~d}$. & 3,43 & 101 11. 3 s. 5 d. & 3,42 \\
\hline & Altres oficis urbans & $1.91711 .11 \mathrm{s.} 3 \mathrm{~d}$. & 3,26 & 89 ll. 8 s. 3 d. & 3,01 \\
\hline & Jueus & 493 1l. $\quad 2$ d. & 0,84 & $25111 \mathrm{~s} .2 \mathrm{~d}$ & 0,84 \\
\hline \multirow[t]{2}{*}{ Eclesiàstics } & Inst. religioses (5) & 7.584 11. 6 s. 2 d. & 12,89 & 36811.15 s. 3 d. & 12,47 \\
\hline & Religiosos & 2.004 11. $3 \mathrm{~s} .1 \mathrm{~d}$. & 3,41 & 78 1l. 3 s.11d. & 2,64 \\
\hline
\end{tabular}




\begin{tabular}{|l|l|l|l|l|l|}
\hline & Causes pies & $1.26011 .2 \mathrm{~s} .8 \mathrm{~d}$. & 2,14 & $6211.1 \mathrm{~s}$. & 2,1 \\
\hline Desconeguts & & $7.67411 .4 \mathrm{~s} .2 \mathrm{~d}$. & 13,04 & $41711.1 \mathrm{~s} .3 \mathrm{~d}$. & 14,14 \\
\hline Total & & $58.82411 .16 \mathrm{s.6 \textrm {d } .}$ & 100 & $\begin{array}{l}2.94811 .4 \mathrm{~s} . \\
5{\mathrm{~d} . \mathrm{m}^{\mathrm{a}}}\end{array}$ & 100 \\
\hline
\end{tabular}

(5) En aquest epígraf hem inclòs dos censals que, l'any 1393, estaven administrats per marmessories, però que poc temps després els assignaren a beneficis religiosos. Concretament, el capital d'aquestes dues rendes pujava a $11411.6 \mathrm{~s}$. i les pensions a $211.11 \mathrm{~s} .2 \mathrm{~d}$.

Quadre $n^{\circ} 6$ : El perfil social dels creditors l'any 1421

\begin{tabular}{|c|c|c|c|c|c|}
\hline & Grups socials & Capital & $\%$ & Pensions & $\%$ \\
\hline \multirow[t]{8}{*}{ Laics } & Ciutadans (Girona) & 6.83111 .18 s. 5 d. & 13,07 & 17011.16 s. $3 \mathrm{~d}$. & 12,2 \\
\hline & Dones & 7.92311 .17 s. $2 \mathrm{~d} . \mathrm{m}^{\mathrm{a}}$ & 15,16 & $21911.10 \mathrm{~s} .9$ d. $\mathrm{m}^{\mathrm{a}}$ & 15,62 \\
\hline & Noblesa & $1.12611 .15 \mathrm{~s}$ & 2,16 & 28 1l. 3 s. $1 \mathrm{~d}$. & 2 \\
\hline & Juristes & 1.495 11.12s. $6 \mathrm{~d}$. & 2,86 & 3611.12 s. 9 d. & 2,64 \\
\hline & Mercaders & 2.448 11. 18 s. 6 d. & 4,68 & 63 11. $6 \mathrm{~s}$. & 4,5 \\
\hline & Indústria tèxtil & 1.160 ll. 6 s. 8 d. & 2,21 & 29 11. $\quad 11 \mathrm{~d}$. & 2,07 \\
\hline & Altres oficis urbans & & & & \\
\hline & Jueus & & & & \\
\hline \multirow[t]{3}{*}{ Eclesiàstics } & Instit. religioses (6) & 17.87611 & 34,2 & 50511.11 s. 11 d.m $\mathrm{m}^{\mathrm{a}}$ & 36,09 \\
\hline & Religiosos & 1.183 1l. 12 s. $10 \mathrm{~d}$. & 2,17 & 2811.7 s. 1 d.m ${ }^{a}$ & 2 \\
\hline & Causes pies & 5.031 ll. 4 s. 5 d. & 10,14 & 14911.15 s. $1 \mathrm{~d} . \mathrm{m}^{\mathrm{a}}$ & 10,7 \\
\hline Desconeguts & & 6.98311 .10 s. $9 \mathrm{~d} . \mathrm{m}^{\mathrm{a}}$ & 13,35 & 171 11. 7 s. 9d. & 12,18 \\
\hline Total & & $52.28211 .10 \mathrm{~s} \quad 4 \mathrm{~d}$ & 100 & 1.402 11. 11 s. 9 d. & 100 \\
\hline
\end{tabular}

Com pot veure's, la principal diferència entre 1393 i 1421 fou el considerable creixement que experimentà l'estament eclesiàstic dins el conjunt de creditors de Castelló d'Empúries. En total, l'any 1421, aquest grup era propietari del $46,51 \%$ del capital degut per la universitat, cosa que suposava cobrar el $48,79 \%$ de les pensions censals. Fonamentalment, aquest canvi s'explica per l'enorme importància que havien adquirit les institucions 
religioses respecte a 1393, ja que quasi havien triplicat el seu pes ${ }^{55}$. Entre totes aquestes institucions, sobresortia l'església castellonina de Santa Maria amb 94 censals (58 censals morts i 36 censals perpetuals), el capital dels quals ascendia a 14.197 1l. 6 s. 1 d. i els interessos anuals a 400 ll. 3 s. 4 d. Així mateix, també cal mencionar l'ascens de les obres pies, que passaren de drenar un escàs $2,10 \%$ dels interessos del deute el 1393, a una desena part el $1421^{56}$. Finalment, a més distància trobem els religiosos a títol particular, que cobraven el $2,17 \%$ de les pensions anuals ${ }^{57}$.

Com ja hem apuntat, l'augment d'aquest col·lectiu fou sobretot conseqüència de les nombroses donacions de censals que realitzaren els creditors laics al llarg d'aquest període, especialment des del moment en què el censal va perdre bona part del seu caràcter especulatiu. Des d'aquest punt de vista, és comprensible que molts censalistes benestants traspassessin llurs rendes a l'Església i abandonessin, de mica en mica, el mercat del deute castelloní $^{58}$. A ulls d'aquests creditors, els censals també es convertiren en un

${ }^{55}$ La rellevància d'aquest grup durant el s.XV també s'observa en altres localitats catalanes, com ara Cervera, Manresa, Valls, Reus, les universitats de la baronia de la Llacuna o Almenar: P. VERDÉS, "Per co que la vila vage a perdició", p.468; M. TORRAS, El deute públic a la ciutat de Manresa pp.179-180; J. MORELLó Fiscalitat $i$ deute públic cit pp 798-800; IDEM, Municipis sota la senyoria, p. 123 i pp.204-205; Josep FORNS BARDÁ, É Énomia $i$ societat en els regs històrics occidentals catalans: Almenar '(Segrià) i la seva àrea (segles XIV-XIX), Girona, Ajuntament de l'Almenar - Publicacions de l'Abadia de Montserrat, 2004, pp.52-53).

${ }^{56}$ En el cas de Castelló d'Empúries, la majoria d'obres pies eren locals, destacant entre totes elles la Caritat (32 11. 19 s. 10 d. anuals), tot i que també cal esmentar 1'Almoina del Pa de la Seu de Girona (75 ll. anuals): AHG, FN, Castelló, $n^{0} 1850$, ff. 20 v.-23 r.; AHG, FN, Castelló, n ${ }^{\circ}$ 1945 , ff. $134 \mathrm{v} .-136$ r. i ff. 164 v.-166 r. A nivell general, des de finals del s. XIV i al llarg de la següent centúria es constata com el deute censal, especialment públic, esdevingué una base de finançament fonamental per aquestes institucions. Vegeu, per exemple: Xavier RIVERA SENTÍS, L'administració de l'hospital d'en Castelltort l'any 1492, un segle després de la seva fundació, "Miscel-lània Cerverina", 11 (1997), p.104; Salvador CLARAMUNT, Los ingresos del "Bací o Pla dels Pobres» de la parroquia de Santa Maria del Pi de Barcelona, de 1434 a 1456, dins Manuel RIU (dir.), La pobreza y la asistencia a los pobres en la Cataluña medieval, vol. I, Barcelona, CSIC, 1980, pp.383-386; Ana Magdalena LORENTE, El Plato de los Pobres Vergonzantes de la parroquia de Santa Maria del Mar, dins M. RIU (dir.), La pobreza y la asistencia a los pobres, cit., vol. II, 1982, p.166; Prim BERTRAN, L'Almoina de la Seu de Lleida a principis del segle XV, dins M. RIU (dir.), La pobreza y la asistencia a los pobres, cit. vol. II, 1982, pp.352-353.

${ }^{57}$ Aquests clergues i preveres -tal com són designats pels capbreus- gairebé sempre acabaven traspassant llurs censals a la comunitat religiosa a la qual pertanyien després de la seva mort, motiu pel qual hem considerat convenient incloure'ls dins l'estament eclesiàstic. Concretament, hem comptabilitzat fins a 14 censals morts en mans de sengles religiosos entre 1386 i 1421 , onze dels quals només els utilitzaren per assegurar-se en vida la corresponent pensió anual, assignantlos a un benefici religiós després de la seva mort. En certa manera, doncs, es podria dir que aquests creditors constituïren un estadi intermedi abans que les seves rendes arribessin definitivament a mans de l'Església. A nivell més general, una actitud similar s'observa a la ciutat de València a finals del s. XIV, per la qual cosa Juan Vicente García Marsilla qualifica aquests religiosos "d'avanzadilla del clero" (J.V. GARCÍA MARSILLA, Vivir a crédito en la Valencia medieval, p.277).

${ }^{58}$ A partir del cas de Manresa, Marc Torras opinava que, «en disminuir els interessos, paulatinament els censals van deixạ de ser considerats com una inversió altament rendible per part de les capes més benestants i adinerades de la burgesia manresana i barcelonina, i que progressivament anés canviant el perfil de l'inversor en aquest deute públic» a favor -afegiríemde l'estament eclesiàstic (M. TORRAS, El deute públic a la ciutat de Manresa, p.180). En aquest sentit, existeixen força exemples paradigmàtics de grans mercaders que, en una context general de davallada d'interessos, llegaren bona part de les seves rendes a institucions religioses o caritatives. Vegeu, per exemple: X. RIVERA, L'administració de l'hospital, pp.95-122; IDEM, Testament d'en Berenguer de Castelltort, mercader ciutadà de Barcelona, fundador de l'Hospital que porta el seu nom, "Miscel·lània Cerverina", 13 (1999), pp.183-213; IDEM, Ramon Serra el Vell: poder, condició $i$ caritat d'un mercader cerveri a les acaballes del segle XIV . "Miscel-lània Cerverina", 10 (1996), pp.37-70; Carles DÍAZ MARTÍ, Bertran Nicolau, fundador de Sant Jeroni 
instrument ideal per a satisfer les seves necessitats pietoses, ja que la manifesta manca de liquiditat del municipi gairebé feia impensable la redempció de les rendes, la qual cosa assegurava un ingrés indefinit a una institució consagrada a la salvació de l'ànima del difunt ${ }^{59}$. Així doncs, per una o altra raó (pèrdua d'interès o irredimibilitat), sembla evident que, com a conseqüència de la crisi financera del municipi, molts laics optaren per traspassar els seus censals a institucions religioses.

A jutjar pels quadres, però, no sembla que a tots els creditors laics els menés la mateixa lògica, sobretot en el cas d'aquells que, molt probablement, havien invertit en deute públic castelloní amb un propòsit rendista. Això explica l'existència de censalistes que es resistien a desprendre's de les seves rendes, tot $\mathrm{i}$ els greus símptomes d'insolvència de la tresoreria de la capital emporitana. Ens estem referint, sobretot, a aquells ciutadans de Girona descendents de famílies patrícies prou conegudes pel que fa el s. XIV, i també a altres col·lectius socials, entre els quals destaquen les dones ${ }^{60}$.

Com és sabut, els membres de l'elit econòmica i política gironina invertiren una bona part de la seva riquesa - entre altres activitats - en l'adquisició de nombrosos censals i violaris emesos per diverses corporacions municipals, a fi de consolidar llur patrimoni i reforçar el seu estatus social privilegiat $^{61}$. A partir dels capbreus, hem comptabilitzat fins a 32 censals morts que, durant tot el període comprès entre 1386 i 1421 , en un moment o altre

de la Murtra, Badalona, Museu de Badalona, 2006; P. ORTÍ, La deuda pública municipal en una pequeña ciudad, p.101. De totes maneres, això no significa que alguns d'ells deixessin d'utilitzar els censals amb finalitats rendistes, tal com es manifesta, per exemple, en els mercaders de la Barcelona del s. XV: Jaume AURELL, Els mercaders catalans al Quatre-cents: mutació de valors i procés d'aristocratització a Barcelona (1370-1470), Lleida, Pagès, 1996, p. 329.

${ }^{59} \mathrm{No}$ oblidem tampoc que, en el cas dels censals perpetuals, aquesta funció es fa palesa des del mateix moment de la șeva aparició, a principis de la dècada de 1380 . Sens dubte, el fet que no poguessin ser redimits no només provocá que les institucions religioses i caritatives s'interessessin ben aviat en comprar-los directament a la universitat, sinó també que els creditors laics els creessin ex professo per a garantir el manteniment d'un benefici religios post mortem. Bona prova d'això és que, dels 55 censals perpetuals que anualment pagava el municipi l'any 1421,46 eren propietat de comunitats religioses, 37 dels quals assignats a un benefici. Vegeu els casos similars de Cervera i Sant Feliu de Guíxols, localitats on també es van emetre censals perpetuals en les dècades de 1370 i 1380 , i que tingueren com a principals compradors aquest tipus d'institucions o persones laiques que pretenien establir fundacions pies: P. VERDÉS, "Per ço que la vila no vage a perdició", cit. pp.102-103; IDEM, "Per tal que no calgués a logre manlevar”, p.35; P. ORTí, La deuda pública municipal en una pequeña ciudad, p.101.

${ }^{60}$ Òbviament, la davallada d'un altre grup tradicionalment rendista com era la noblesa dins l'endeutament castelloní entre 1393 i 1421 no pot ser únicament atribuible a la pèrdua del valor especulatiu dels censals morts. En aquest sentit, Anthony Pinto assenyala que la desaparició de la segona nissaga comtal l'any 1401 va comportar l'emigració de Castelló d'Empúries d'algunes famílies de la noblesa empordanesa fins llavors molt vinculades a la cort dels comtes. Encara que només sigui una hipòtesi, potser aquest fet també pesà a l'hora de traspassar llurs rendes a l'estament eclesiàstic: A. PINTO, Commerce et draperie, vol. III, p.668. Sobre la importància de la noblesa en altres indrets, sobretot a diversos municipis del regne de València, vegeu la síntesi d'A. FURIÓ, Deuda pública e intereses privados. p.78.

${ }^{61}$ Aquests prohoms no només van invertir en l'endeutament de la capital emporitana, sinó també en el de moltes altres universitats del comtat, com ara Roses, Esponellà, Cadaqués, la Tallada, Monells, Ullastret o Verges, així com en d'altres municipis del nord est català, com per exemple Perpinyă, Figueres, Banyoles, Camprodon o Peralada: Christian GUILLERÉ, Girona al s. XIV , Girona, Ajuntament de Girona; Publicacions de l'Abadia de Montserrat, vol.II, pp.442443; A. PINTO, Commerce et draperie, vol.III, p.696. Vegeu un bon exemple d'aquesta política inversora en la família dels Bell-1loch: Josep FERNÁNDEZ TRABAL, Una famílía catalana medieval: els Bell-lloc de Girona (1267-1533), Barcelona, Publicacions de l'Abadia de Montserrat, 1995, pp. 107-108 i 143 . 
van passar per les mans de creditors que poden adscriure's a aquest col·lectiu. Doncs bé, sense gairebé cap excepció, aquest censals foren utilitzats pels seus propietaris amb la intenció bàsica d'assegurar-se uns ingressos anuals de per vida i/o assegurar-los també als seus successors. Aquesta conducta clarament es manifesta, en primer lloc, en aquells 13 creditors que, pel període analitzat, mantingueren sempre la propietat de les seves rendes; en segon lloc, en aquells altres 12 que només després de la seva mort llegaren llurs rendes a un membre de la seva família o, més excepcionalment, a institucions caritatives; i, per últim, en els nou censalistes que van ser titulars de les rendes durant alguns anys fins que, encara en vida, decidiren donar-les a un familiar. De fet, la donació inter vivos va ser pràcticament l'únic tipus de transmissió de censals que utilitzaren aquests patricis gironins, mentre que les operacions de compravenda foren gairebé inexistents ${ }^{62}$. En altres paraules, tot sembla indicar que aquests il-lustres creditors habitualment no van usar els censals morts castellonins amb una intenció especulativa, tal com van fer altres grups socials, sinó més aviat amb la voluntat d'assegurar-se una font d'ingressos regular al llarg dels anys tant per ells com per a les seves nissagues respectives.

Finalment, en la nòmina de creditors laics del municipi de 1421 també apareix un segon grup força rellevant constituït per mullers (17), vídues (14) o filles (1) d'algú que al llarg dels anys havien anat acumulant un nombre significatiu de rendes. Per bé que aquest col-lectiu és numèricament inferior a la xifra proporcionada el 1393 (41), percentualment experimenten un lleuger increment dins l'endeutament castelloní: mentre que, el 1393, aquestes creditores eren propietàries del 13,22\% del capital degut, que significava cobrar el 13,04\% de les pensions anuals, el 1421 havien passat a tenir el $15,16 \%$ del capital o, el que és el mateix, percebien el 15,62\% dels interessos. Sis d'aquestes creditores - totes vídues, excepte una- ja apareixien en el llistat del 1393, mentre que la resta s'hi convertiren a través de donacions de censals, ja fos del fill (2); per deixa testamentària del seu marit (2) o d'algun dels seus familiars (6); o bé perquè algun dels seus progenitors havia inclòs la renda en el seu dot $(11)^{63}$. Segurament, el propòsit principal de la majoria dels donadors d'aquests censals, normalment pares o marits, era assegurar mercès a una renda anual el sosteniment d'aquells familiars socialment més desemparats enfront de qualsevol eventualitat, habitualment la futura desaparició del cònjuge. Concorda amb aquesta hipòtesi l'ús que aquestes creditores, gairebé sense excepció, van fer dels censals rebuts, que no fou altre que procurar-se una pensió anual al llarg de la seva vida. Aquesta actitud, comuna a totes elles

\footnotetext{
${ }^{62}$ Entre 1386 i 1421 tan sols dos creditors vengueren les seves rendes, tot i que un d'ells, Bernat Sarriera, ho féu al seu oncle Guillem: AHG, FN, Castelló, no ${ }^{\circ} 1945$, ff. 156 r.-157 r.

${ }^{63}$ Només en el cas de cinc creditores no hem estat capaços de determinar el mecanisme pel qual es van fer amb la propietat d'un censal.
} 
independentment de la seva pertinença social, creiem que justifica haver-les agrupat en una categoria específica ${ }^{64}$.

\section{CONSIDERACIONS FINALS}

Arribats a aquest punt, creiem haver mostrat que els dos capbreus de censals estudiats constitueixen unes fonts excepcionals per aproximar-se a l'evolució del deute públic de Castelló d'Empúries durant un període (13861421) clarament marcat per les greus dificultats financeres que experimentà la tresoreria municipal. Certament, aquests memorials tan sols poden considerarse com una punta d'iceberg, atès que encara hi ha una important massa documental inèdita, que conté molta més informació sobre els orígens i la consolidació del sistema fiscal i financer de la capital emporitana des de mitjan del s. XIV ${ }^{65}$ No obstant, gràcies a l'anàlisi dels capbreus de censals ja estem en condicions de fer algunes consideracions d'interès sobre l'endeutament dels municipis catalans a la Baixa Edat Mitjana.

En primer lloc, tal com avançàvem en la introducció d'aquest treball, l'exemple de Castelló d'Empúries ens ha servit per comparar l'evolució financera d'un lloc de senyoriu amb la d'altres poblacions de reialenc. En principi, es podria pensar que els municipis senyorials s'haurien pogut resguardar, en certa mesura, de l'elevada pressió fiscal que la monarquia exercí sobre les poblacions del seu domini, des de mitjan del s. XIV. Tanmateix, l'estudi del llibre de comptes de 1381-1382 mostrava que el sistema fiscal i financer de Castelló d'Empúries era idèntic al que s'havia consolidat en els municipis reials durant el mateix període. I no només això: l'anàlisi del "manual de reduccions" de 1386-1387 donava fe dels greus problemes financers que comportà l'augment dels interessos del deute per a les arques locals, així com de les estratègies que el consistori hagué d'emprendre per tal de pal·liar aquesta delicada situació. Per tant, la crisi financera que

\footnotetext{
${ }^{64}$ Diferents autors han assenyalat aquesta funció del censal en tant que subsidi de viduïtat a partir de la radiografia social del deute d'altres municipis catalans, com ara Manresa, Cervera i Reus, o fora de Pàmbit català, Gandia i Borriana: M. TORRAS, El deute públic a la ciutat de Manresa, p.182; P. VERDÉS, "Per tal que no calgués a logre manlevar", p.50; J. MORELLÓ, Fiscalitat l deute públic , cit. p.787. Vicent OLASO, L'endeutament censal a la vila de Gandia durant la baixa Edat Mitiana, "Ullal", 1 (1987), p.6; Pau VICIANO, Fiscalitat local i deute públic al País Valencià. L'administració de la vila de Borriana a mitjan segle XV, "Anuario de Estudios Medievales", 22 (1992), p.525. Aquesta era també una de les finalitats principals dels compradors de censals (privats i públics) en la societat del Vallès baixmedieval: M. AVENTÍN, La societat rural a Catalunya en temps feudals, Barcelona, Columna, 1996, p. 403. Així mateix, no deixa de ser revelador que les compres de violaris 1 censals morts privats -garantits amb la venda simulada de llibres- a la Barcelona del s. XV fossin protagonitzades per dones, ja fossin vídues, mullers o encara no maridades: Josep HERNANDO, Crèdit i llibres a Barcelona, segle XV. Els contractes de venda de rendes (censals morts $i$ violaris) garantits amb vendes simulades de llibres. El llibre, instrument economic i objecte de cultura, "Estudis Històrics i Documents dels Arxius de Protocols", XVIII (2000), pp.48-49.

${ }^{65}$ Entre moltes altres sèries documentals, considerem fonamental l'estudi dels llibres de la clavaria conservats a l'Arxiu Històric de Girona que, sense gaires llacunes, permeten resseguir l'evolució de la hisenda local des de 1358 fins, com a mínim, l'inici de la guerra civil catalana el 1462. Vegeu una breu descripció d'una part d'aquest fons a M. SÁNCHEZ, Fiscalidad y finanzas de una villa, cit. pp.309-312.
} 
testimonien els capbreus de censals, des de les primeres suspensions de pagaments el 1393 fins al final del procés de sanejament del deute el 1421, no fa sinó redundar en la constatació de què la barrera jurisdiccional dels municipis senyorials no fou cap obstacle per evitar ni l'escalada del deute en llurs tresoreries, ni els problemes derivats del seu creixement.

Més enllà, però, de constatar aquesta coincidència, caldria esbrinar els motius que provocaren, precisament, la nova suspensió de pagaments de les pensions censals a Castelló d'Empúries a finals del s. XIV; fet que, almenys aparentment, és força sorprenent, si tenim en compte que s'acabava d'efectuar un important procés de reducció del deute entre 1386 i 1393. Evidentment, fins que no puguem estudiar altres fonts documentals ens mourem en el terreny de l'especulació, però aquí voldríem apuntar algunes causes probables. Així, per exemple, la manca de recursos de la tresoreria es podria atribuir a la contracció demogràfica i econòmica de Castelló d'Empúries en aquest període, que segurament es traduí en una reducció de la massa contributiva de la població i, per tant, en una davallada dels ingressos fiscals ordinaris del municipi ${ }^{66}$. Així mateix, cal tenir en compte les necessitats pecuniàries de la universitat al llarg d'aquests anys, ja fossin de la pròpia comunitat (reparació o construcció de les muralles, abastament frumentari, etc.) o bé com a conseqüència de la pressió fiscal ordinària o extraordinària exercida per l'autoritat corresponent (les Corts, la monarquia o la senyoria). Per últim, un darrer element que cal posar sobre la taula és el grau d'endeutament que, tradicionalment, s'ha atribuït a la hisenda dels comtes d'Empúries al llarg de tota la catorzena centúria. Com hem dit, la segona nissaga comtal s'extingí el 1402 i, per tant, caldria saber si en els anys immediatament anteriors es produí alguna transferència de deutes contrets pels comtes d'Empúries a la universitat castellonina que pogués haver aguditzat el precari equilibri fiscal i financer de la vila.

A més de mostrar els problemes ocasionats pel deute censal, els memorials de rendes també exemplifiquen les estratègies financeres que moltes localitats catalanes endegaren entre finals del s. XIV i, sobretot, durant el s. $\mathrm{XV}$, a fi de disminuir el volum total de les pensions anuals i d'equilibrar els comptes municipals. En el cas castelloní, ja hem vist que aquestes mesures es concretaren en un llarga i difícil negociació amb els creditors per tal que accedissin a rebaixar sensiblement el tipus d'interès dels censals morts fins a un $2,5 \%(1410-1421)$.

Ara bé, aquest procés de reducció del deute s'hauria d'entendre més aviat com un final de trajecte, és a dir, que restarien per estudiar tots aquells intents de redreç previs a 1410 que, a tenor de la posterior dinàmica de suspensió, no aconseguiren reeixir. Així doncs, a partir de l'estudi d'altres fonts documentals, caldria analitzar la política fiscal del consistori i esbrinar si s'augmentaren les tarifes de les imposicions (impostos indirectes), si ho féu

\footnotetext{
${ }^{66}$ Una prova d'aquesta difícil conjuntura és la pèrdua de vitalitat de l'activitat tèxtil, el principal motor econòmic de la capital comtal Vegeu-ne les causes a A. PINTO, Commerce et draperie, vol. III, pp.667-677.
} 
la freqüència de les talles (impostos directes) o, fins i tot, si s'establiren noves modalitats impositives com, per exemple, els impostos sobre la renda ${ }^{67}$. Així mateix, també s'hauria de determinar si el govern castelloní implantà mesures de caràcter financer per millorar els mecanismes de pagament de les pensions censals: a la llum d'altres poblacions, sabem que alguns consistoris posaren al capdavant de la clavaria a persones que, a títol particular, avançaven els diners necessaris per a pagar puntualment les anualitats, a canvi de l'assignació dels ingressos municipals i una elevada retribución ${ }^{68}$. I, finalment, també caldria aprofundir en els intents d'avinença amb els creditors -anteriors el 1410 - per tal que reduïssin l'interès de llurs rendes, alguns dels quals els capbreus només deixen entreveure. En aquest sentit, seria fonamental, per exemple, conèixer en què va consistir l'actuació de Lleonard de Sos, l'interventor reial enviat a la vila el 1407, i quin fou el veritable abast de la seva política financera.

Per últim, només ens manca fer una darrera consideració que té a veure amb el rerefons social dels creditors de Castelló d'Empúries al llarg d'aquest període. Com hem pogut comprovar, els inventaris de rendes permeten reconstruir amb prou fiabilitat la composició social i geogràfica dels censalistes en uns anys concrets: 1393 i 1421. A partir d'aquestes dades hem vist com, a grans trets, no van existir diferències significatives respecte a altres municipis catalans: d'una banda, s'observa un protagonisme creixent de l'estament eclesiàstic dins el deute públic castelloní; i, de l'altra, l'important pes dels creditors de les grans ciutats - en aquest cas Girona- en l'endeutament de les poblacions incloses dins el seu hinterland. Més enllà d'això, però, els capbreus de censals també permeten resseguir la dinàmica del mercat secundari del deute $i$, per tant, conèixer en quin tipus d'operacions -i amb quina finalitat- els creditors van utilitzar llurs rendes durant el període estudiat. D'aquesta manera, hem constatat com la crisi financera de la tresoreria provocà la pèrdua del caràcter negociable dels censals, especialment a partir del 1400, quan la suspensió de pagaments començà a fer-se evident. Des d'aquell moment, els creditors laics foren els qui, majoritàriament, van abandonar el mercat del deute castelloní i, mica en mica, cediren els seus censals a l'Església i a institucions benèfiques. Aquesta tendència només es veu matisada per la presència, encara el 1421, de grups socials eminentment rendistes, com ara els ciutadans de Girona o les dones (filles, esposes o vídues d'algú), que deurien valorar, malgrat els evidents problemes d'insolvència de la hisenda castellonina, la pensió censal com una font d'ingressos regular i indefinida.

\footnotetext{
${ }^{67}$ Tal com s'esdevingué en altres llocs de Catalunya: J. MorelLó, Els impostos sobre la renda a Catalunya. Redelmes, onzens i similars, "Anuario de Estudios Medievales", 27/2, 1997, pp.903-968.

${ }^{68} \mathrm{P}$. VERDÉs, "Per ço que la vila no vage a perdició", cit. pp.81-93. Aquesta possibilitat es trasllueix en 19 assentaments dels capbreus que fan referência a sengles pactes formalitzats pel consistori entre 1413 i 1415. En aquests casos, l'escrivà també qualificava al cònsol i clavari que els obtingué, Arnau Camps, de "tauler"; vegeu, per exemple, l'acord de reducció d'interessos que aquest oficial aconsegui amb el prevere Bernat Cortada el 30 de setembre de 1413: AHG, $\mathrm{FN}$, Castelló, no 1945 , ff. 97 r.-97 v.
} 
Sense negar del tot, doncs, la tesi tradicional segons la qual els censals públics només van servir pel sosteniment de capes rendistes de la societat baixmedieval, considerem que s'hauria d'entendre aquest fet com a resultat d'un procés gradual, motivat per les constants crisis financeres dels municipis $i$ les consegüents reduccions generals d'interessos. Des d'aquesta perspectiva, és molt probable que un anàlisi del mercat secundari del deute castelloní durant les dècades centrals del s. XIV, és a dir, en un moment en què els censals i els violaris tenien uns interessos alts i la hisenda local encara no deuria haver mostrat greus símptomes d'impagament, revelaria un mercat de rendes molt més intens que l'observat entre 1386 i $1421^{69}$. Sigui com sigui, i més enllà de l'estudi d'aquest mercat, en el futur caldria elaborar un estudi prosopogràfic prou sòlid com per poder identificar correctament tots aquells individus que participaren, d'una manera o una altra, en el negoci fiscal i financer de Castelló d'Empúries entre els segles XIV i XV.

Data de recepció de l'article: març 2009

Data d'acceptació i versió final: febrer 2010.

${ }^{69}$ I això sense oblidar les possibles assignacions de les pensions anuals que els propietaris de rendes podien realitzar a favor d'una altra persona; operacions que, malauradament, els capbreus de censals no documenten excepte en comptades ocasions. Sens dubte, l'estudi d'aquest qüestió completaria i enriquiria la dinàmica del mercat secundari del deute. 


\begin{tabular}{|l|c|}
\hline 1. Castelló d'Empúries & $53 \%$ \\
\hline 2. Girona & $24 \%$ \\
\hline 3. Barcelona & $3,55 \%$ \\
\hline 4. Figueres & $2,37 \%$ \\
\hline 5. Peralada & $2,10 \%$ \\
\hline 6. Palau de Sta. Eulàlia & $1,57 \%$ \\
\hline 7. Riumors & $1,43 \%$ \\
\hline 8. La Tallada & $1,29 \%$ \\
\hline 9. Fortianell & $1,12 \%$ \\
\hline 10 Perpinyà & $0,94 \%$ \\
\hline 11 Roses & $0,79 \%$ \\
\hline 12. Monells & $0,75 \%$ \\
\hline 13. St. Llorenç de Maçanet & $0,65 \%$ \\
\hline 14. S'Agaró & $0,64 \%$ \\
\hline 15. Banyoles & $0,63 \%$ \\
\hline 16. Batet & $0,53 \%$ \\
\hline 17. Espolla & $0,49 \%$ \\
\hline
\end{tabular}

\section{- Prrpiaya com}

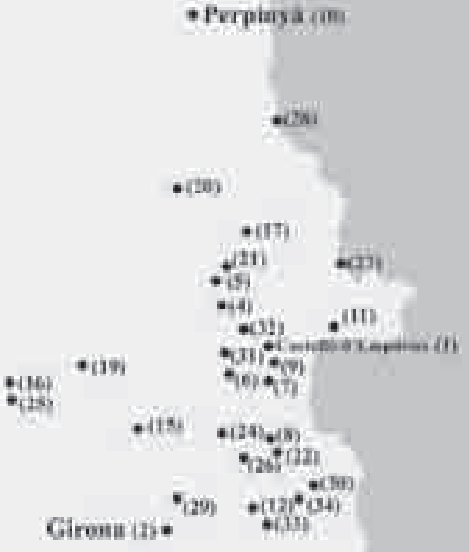

(im)

- Barcelisea ios

\begin{tabular}{|l|c|}
\hline 18. Montmajor & $0,38 \%$ \\
\hline 19. Bellcaire & $0,37 \%$ \\
\hline 20. Sta. Maria de Panissars & $0,36 \%$ \\
\hline 21. Bell-lloch de Peralada & $0,34 \%$ \\
\hline 22. Besalú & $0,33 \%$ \\
\hline 23. Vall de Maria (Maçanet) & $0,32 \%$ \\
\hline 24. Viladasens & $0,31 \%$ \\
\hline 25. St. Privat de Bas & $0,29 \%$ \\
\hline 26. Verges & $0,26 \%$ \\
\hline 27. Llançà & $0,23 \%$ \\
\hline 28. Argelers & $0,19 \%$ \\
\hline 29. Campdorà & $0,19 \%$ \\
\hline 30. Torroella de Montgrí & $0,18 \%$ \\
\hline 31. St. Miquel de Fluvià & $0,15 \%$ \\
\hline 32. Vilanova de la Muga & $0,13 \%$ \\
\hline 33. St. Pol de la Calçada & $0,06 \%$ \\
\hline 34. Ullastret & $0,06 \%$ \\
\hline
\end{tabular}




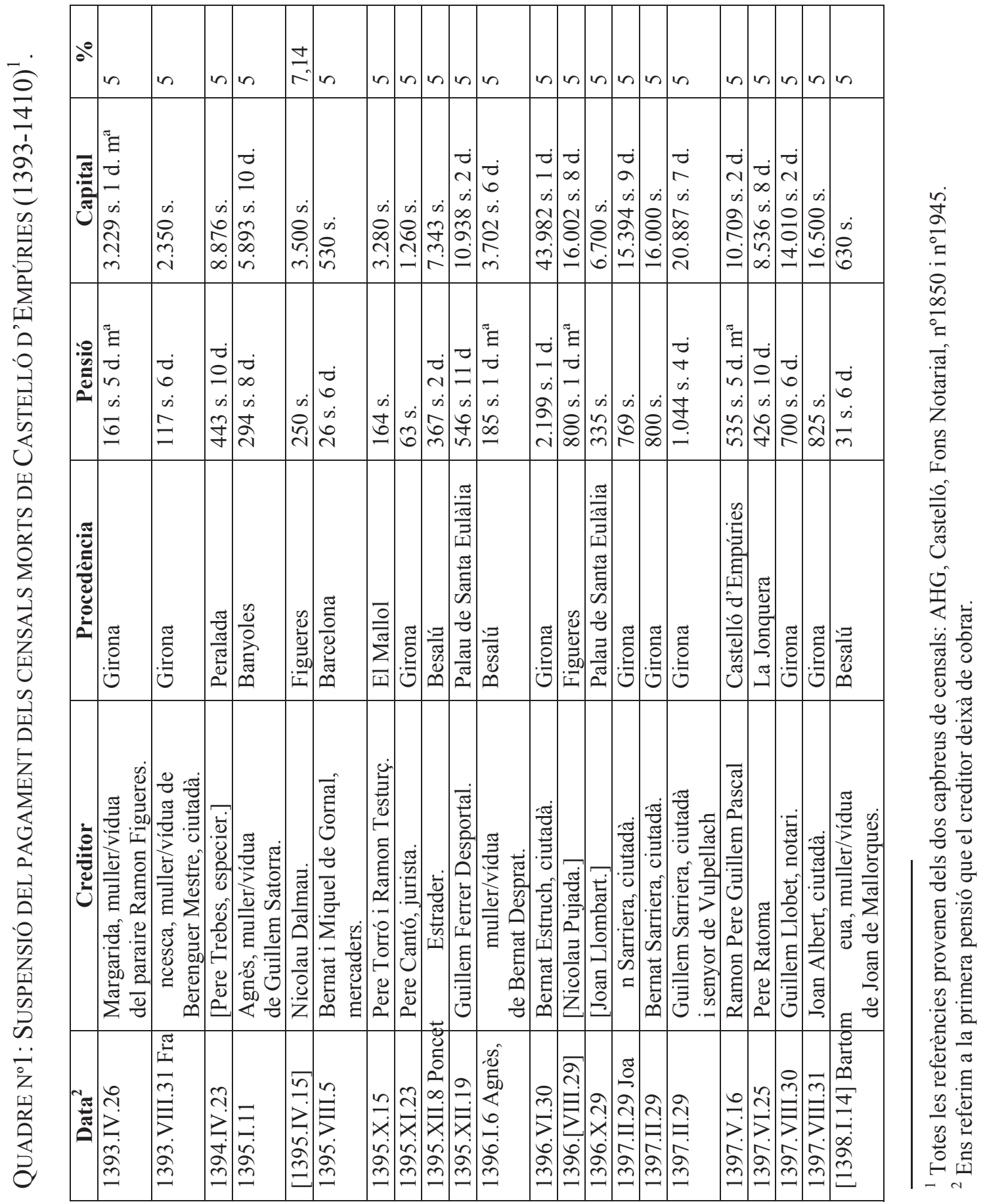




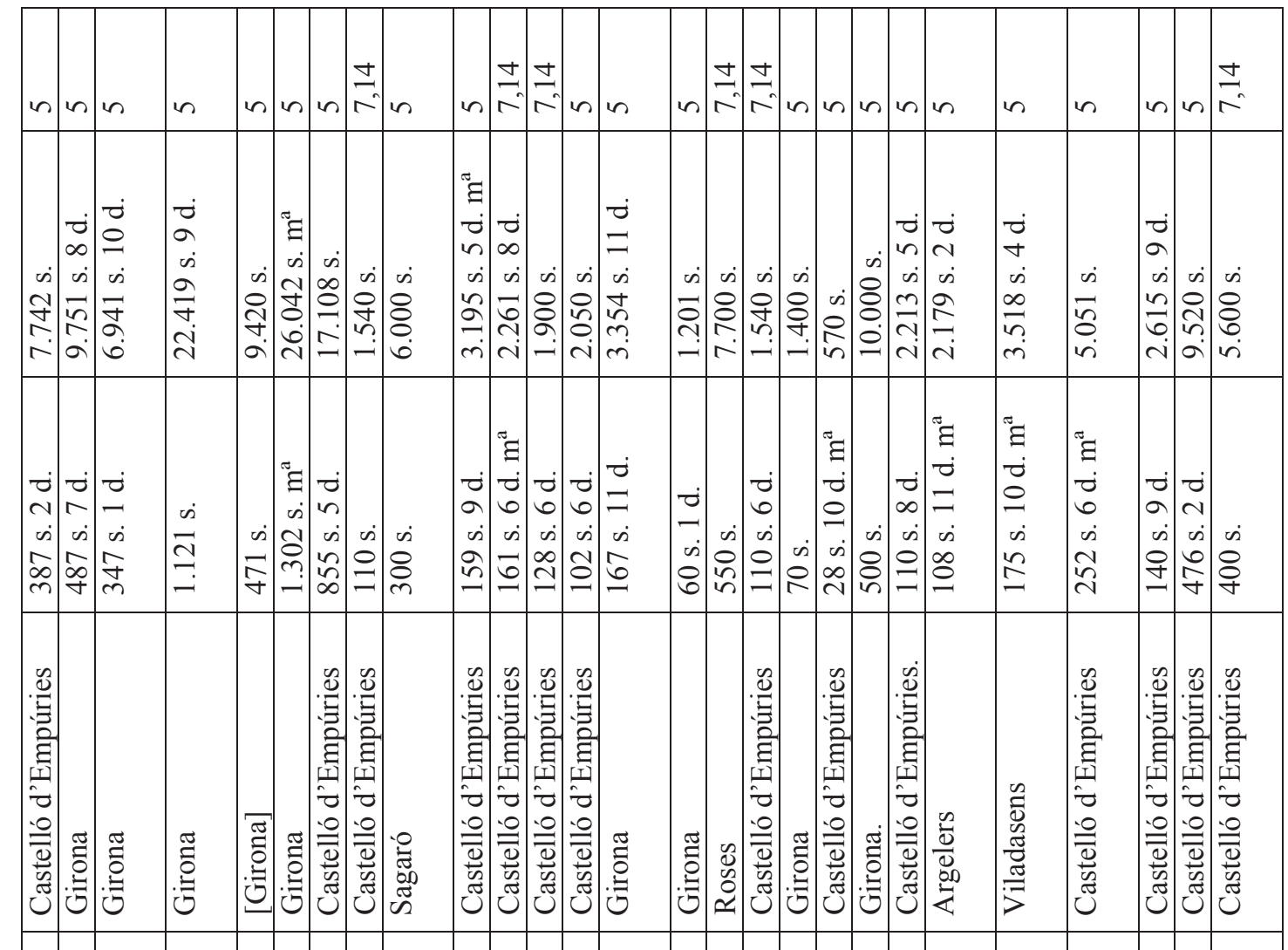

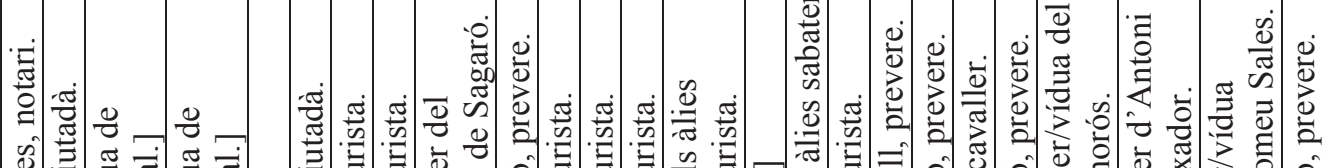

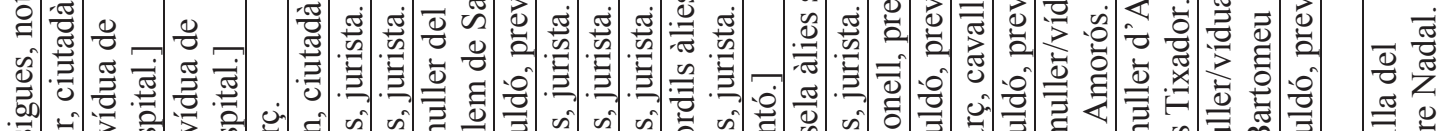

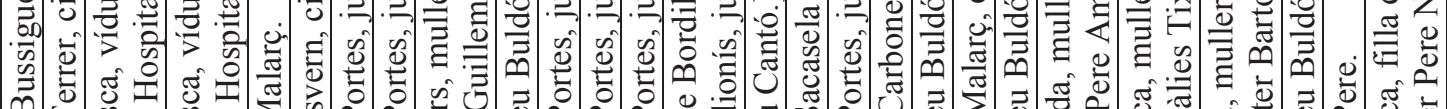

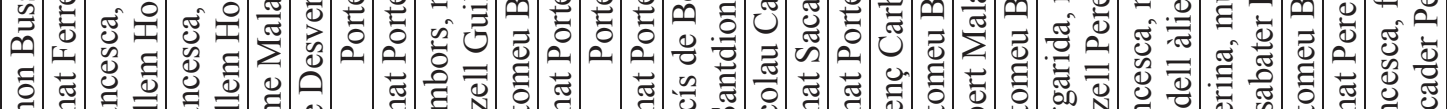

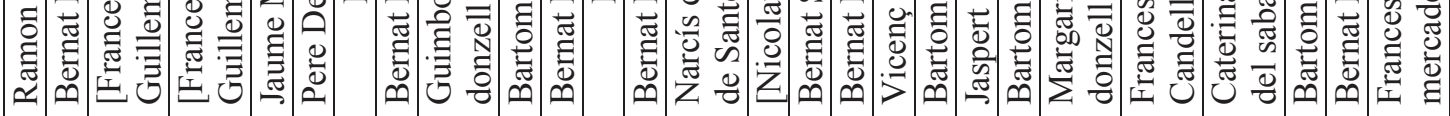

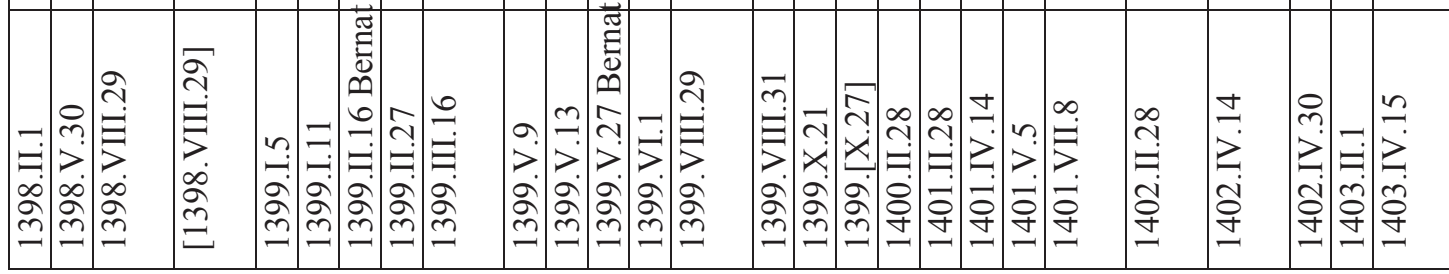




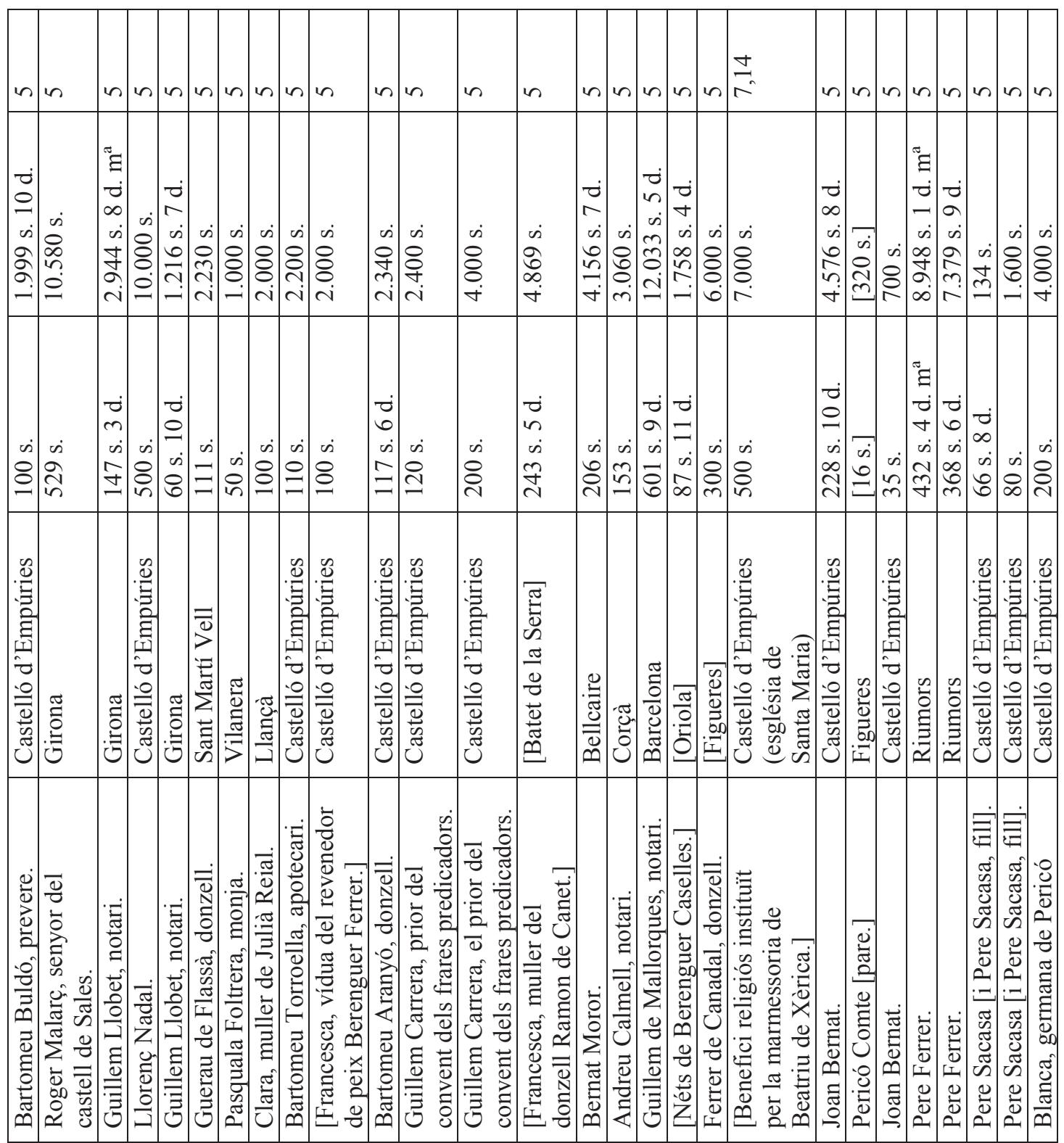

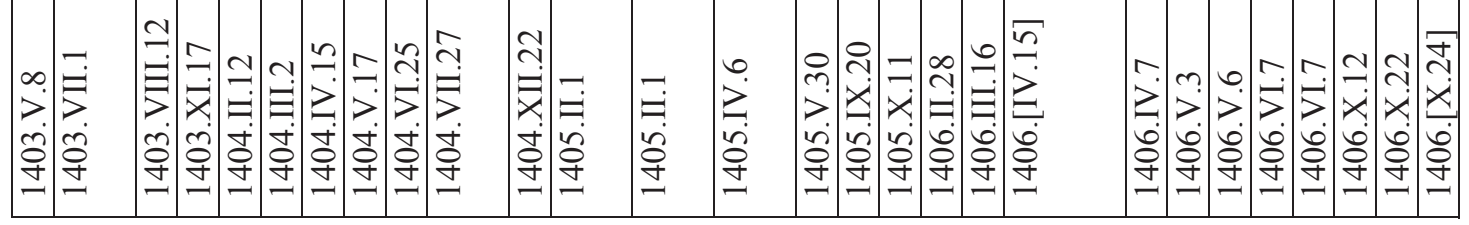




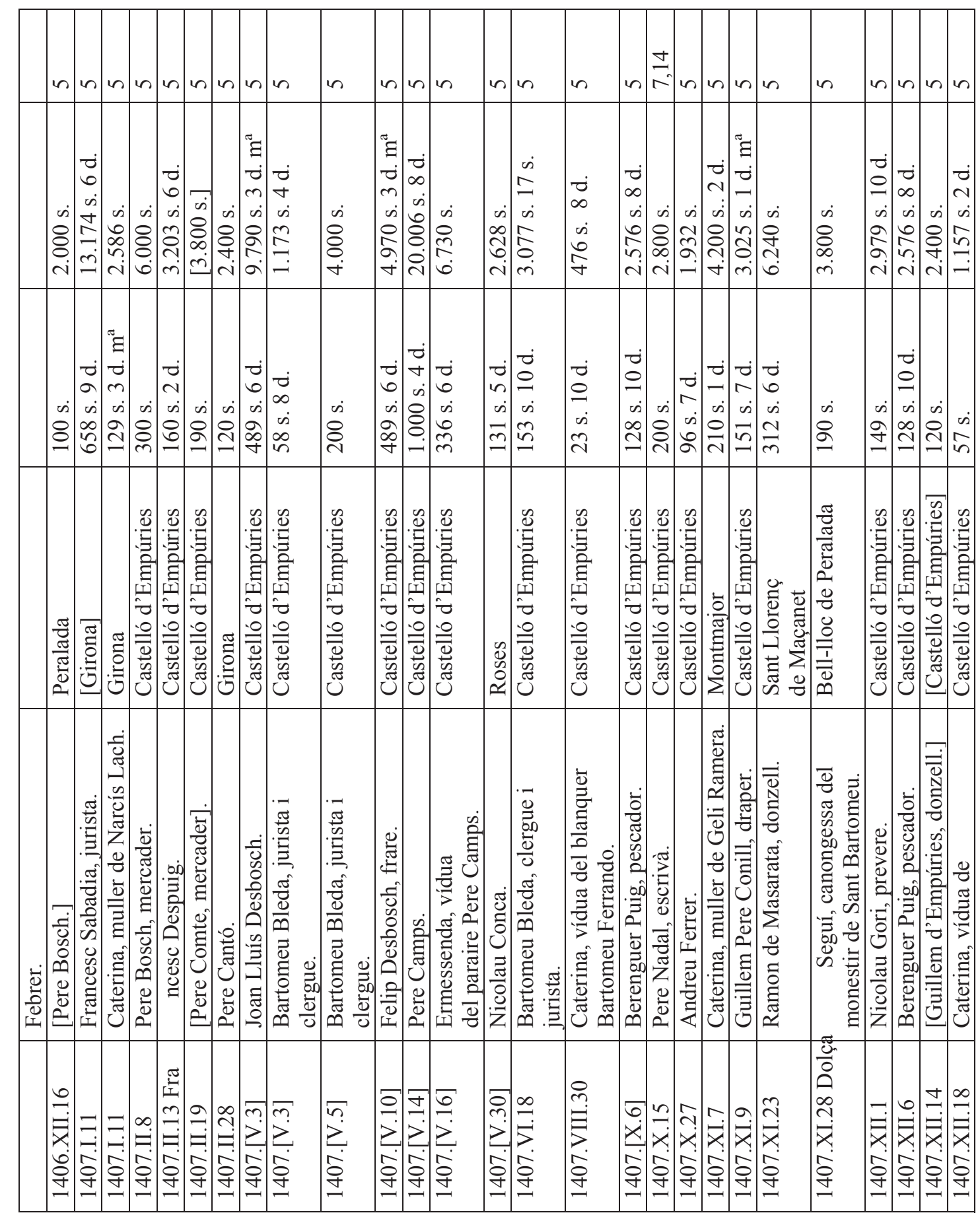




\section{a}

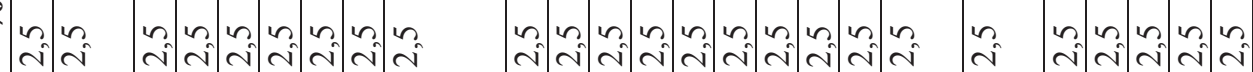

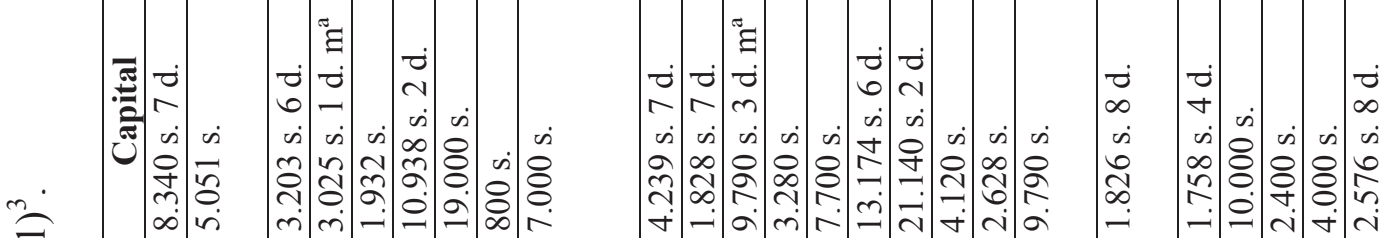

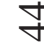

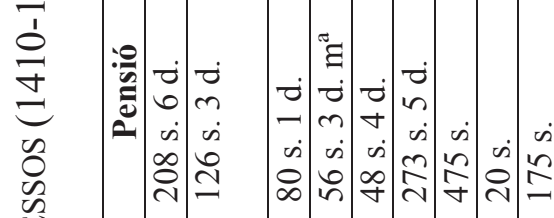

II

r

点

象

$\stackrel{0}{0}$

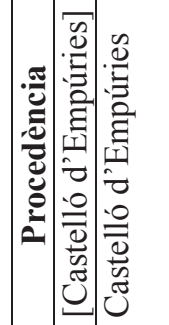

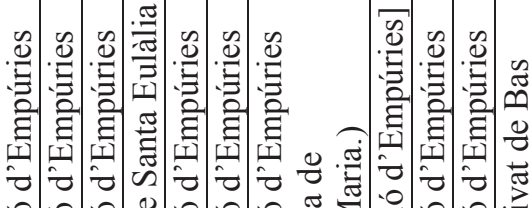

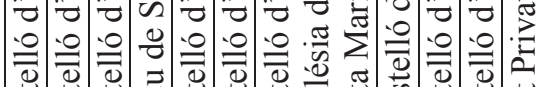

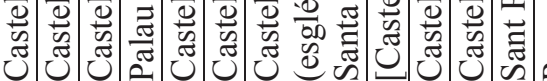

离

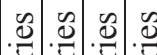

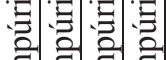

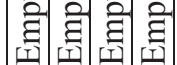

至四望望

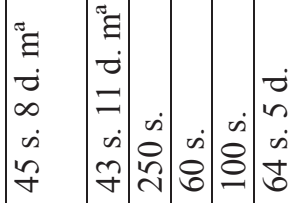

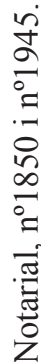

?

$\overline{0} \stackrel{\overline{0}}{\overline{0}}$

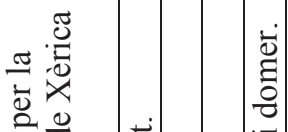

กิ้

4

列

붕

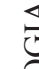

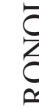

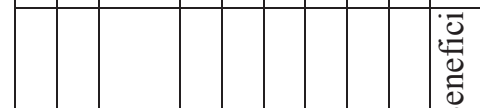

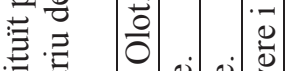

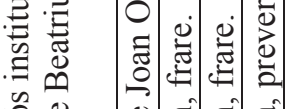

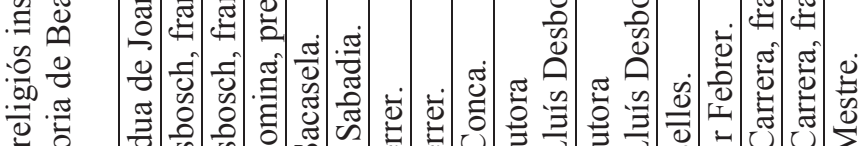

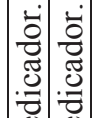

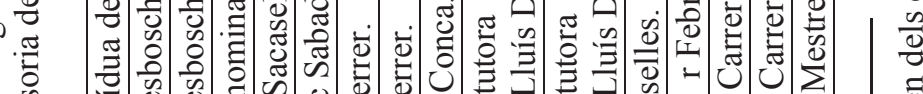

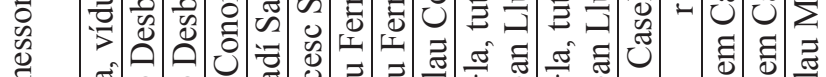

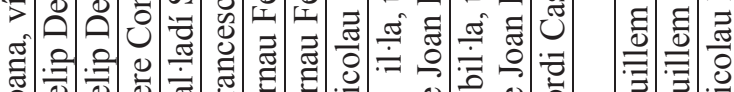

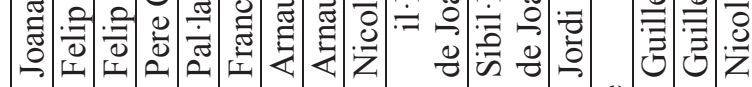

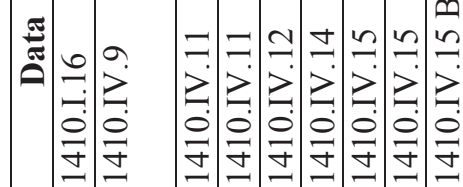




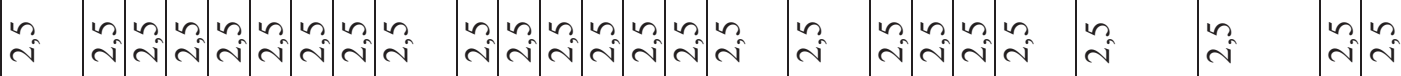

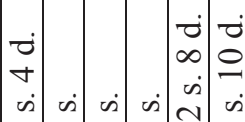

i

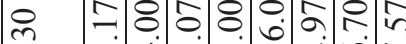

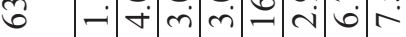

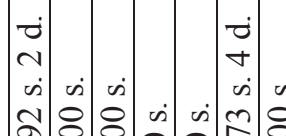

হু

in

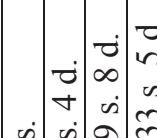

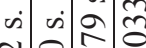

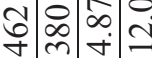

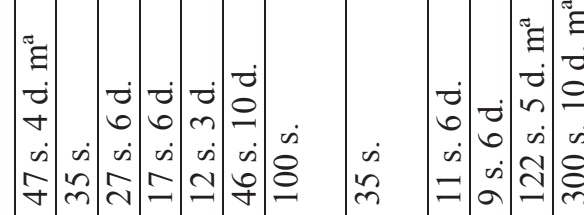

\section{๕ี}

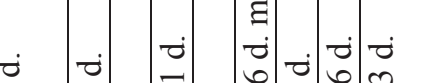

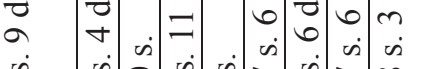

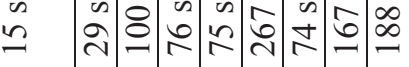

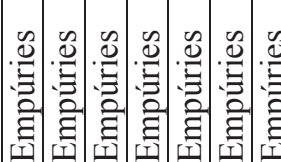

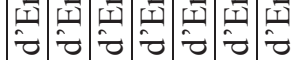

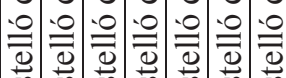

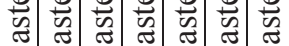

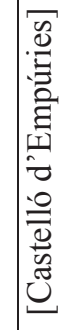

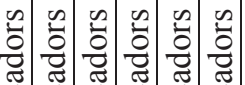

苟

文

\section{$\stackrel{\dot{\Xi}}{\overrightarrow{3}}$

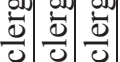 \\ 先}

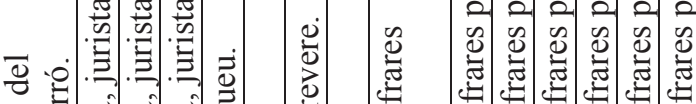

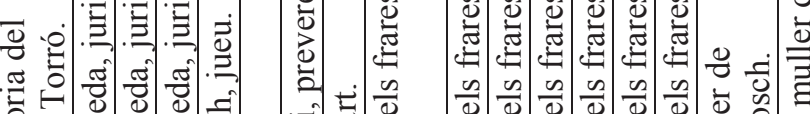

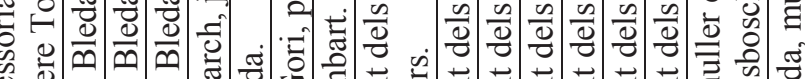

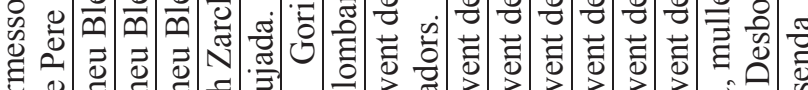

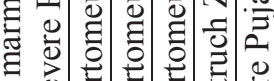

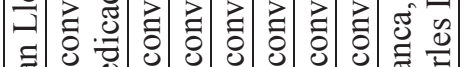 \\ 5}

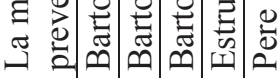

난.

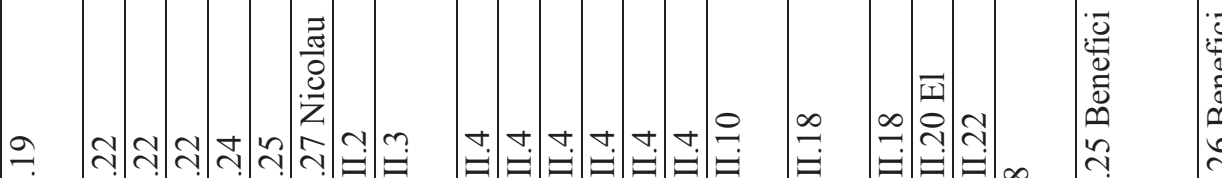

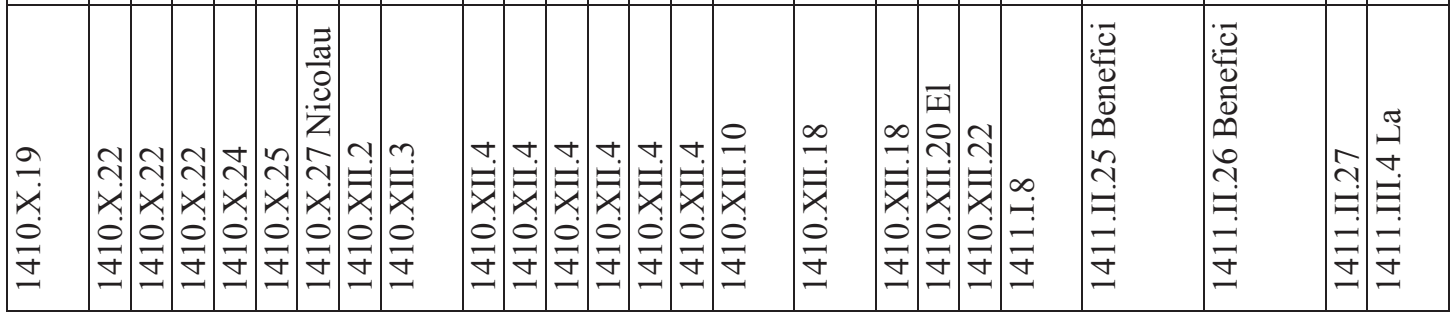




\begin{tabular}{|c|c|c|c|c|c|c|c|c|c|c|c|c|c|}
\hline הi & $\mid$\begin{tabular}{rl|}
$n$ \\
$\mid$
\end{tabular} & 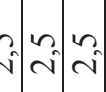 & fin: & $f m$ & $m^{m}$ & $\mid \begin{array}{l}n \\
i \\
i\end{array}$ & $\begin{array}{l}n \\
n \\
i\end{array}$ & $\vec{n}$ & $\mid \begin{array}{l}n \\
i \\
i\end{array}$ & 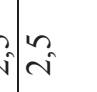 & 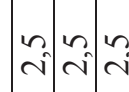 & 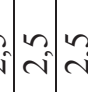 & $\begin{array}{c}n \\
\end{array}$ \\
\hline 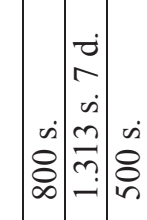 & 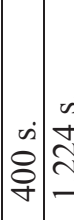 & & 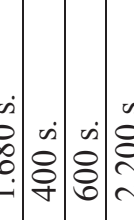 & 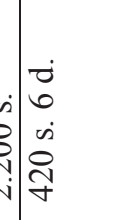 & $\begin{array}{l}\dot{D} \\
\\
\dot{n} \\
\hat{D} \\
\dot{D} \\
\dot{T}\end{array}$ & 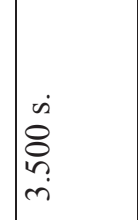 & $\begin{array}{l}\dot{0} \\
\stackrel{9}{9} \\
\end{array}$ & $\begin{array}{l}\dot{1} \\
\stackrel{0}{0} \\
\dot{m}\end{array}$ & 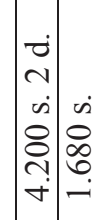 & 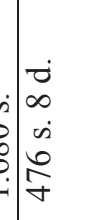 & 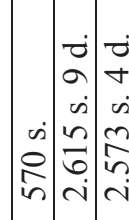 & 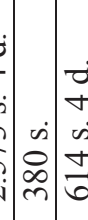 & 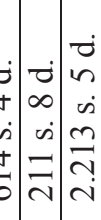 \\
\hline 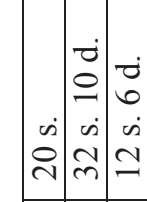 & 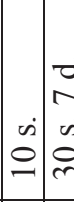 & & 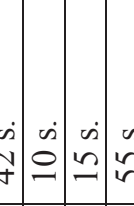 & 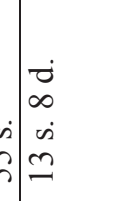 & 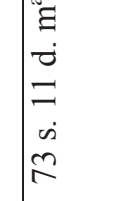 & $\mid \begin{array}{l}\dot{0} \\
0 \\
\dot{0} \\
\infty \\
\infty\end{array}$ & $\begin{array}{l}m \\
m \\
m\end{array}$ & $\mid \begin{array}{l}\dot{0} \\
0 \\
\dot{0} \\
2 \\
2\end{array}$ & 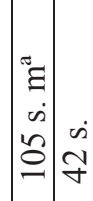 & 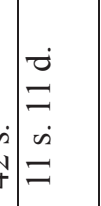 & 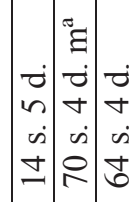 & 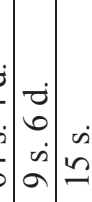 & 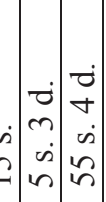 \\
\hline 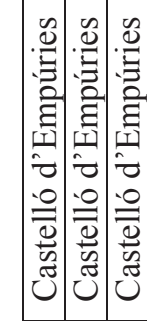 & $\mid \begin{array}{ll} \\
:\end{array}$ & 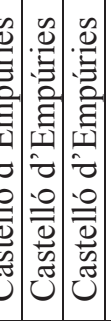 & 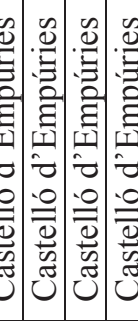 & 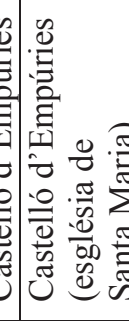 & 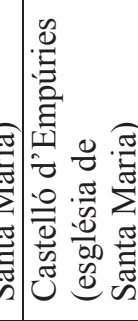 & 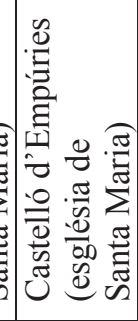 & 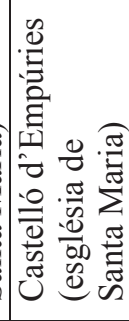 & 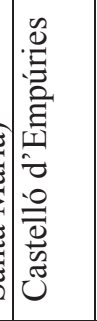 & 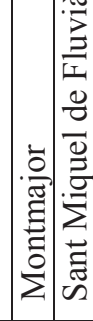 & 童 & 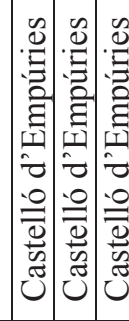 & 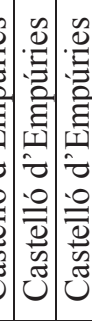 & 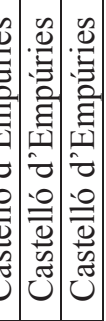 \\
\hline 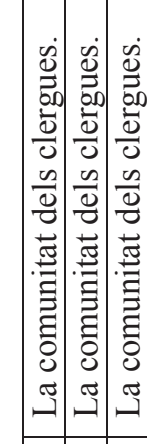 & 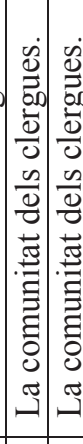 & 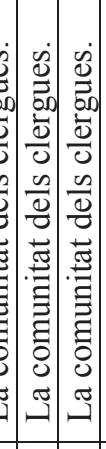 & 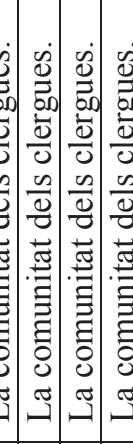 & 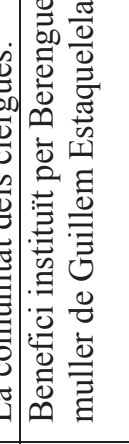 & 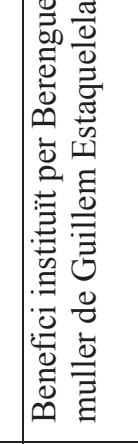 & 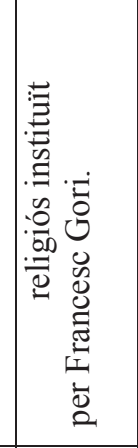 & 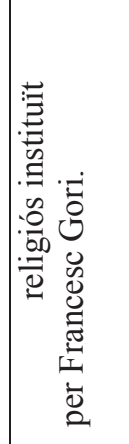 & 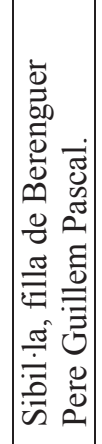 & 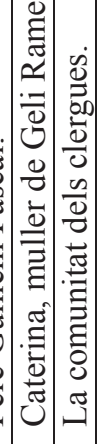 & 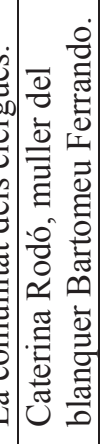 & 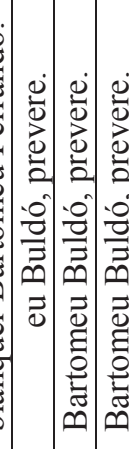 & 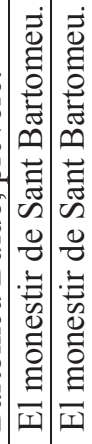 & 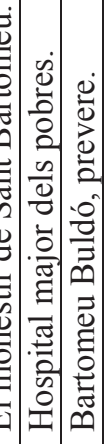 \\
\hline 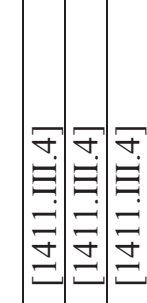 & 可 & 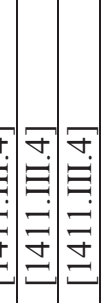 & 呈 & & 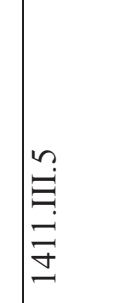 & 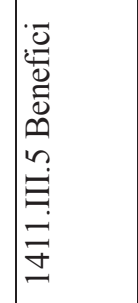 & 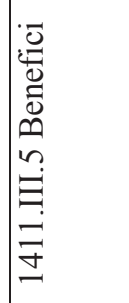 & 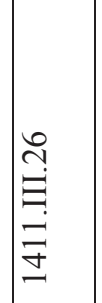 & & 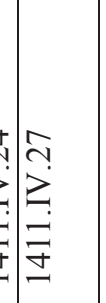 & 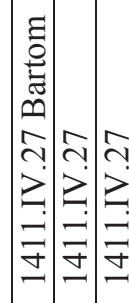 & 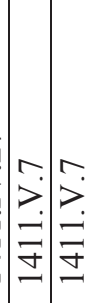 & 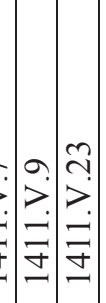 \\
\hline
\end{tabular}




\begin{tabular}{|c|c|c|c|c|c|c|c|c|c|c|c|c|c|c|c|c|c|c|c|c|c|c|c|c|c|}
\hline n & in & $\therefore$ & $\approx$ & in & $\begin{array}{l}n \\
i\end{array}$ & in & n & n & n & n & an & n̂ & $\tilde{n}$ & î & $\stackrel{n}{\sim}$ & ñ & $\stackrel{n}{\sim}$ & ñ & ñ & an & $\begin{array}{c}n \\
\sim\end{array}$ & $\mid$ & ñ & $\approx$ & n \\
\hline $\begin{array}{l}\dot{\rho} \\
\dot{\sigma}\end{array}$ & 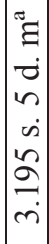 & \begin{tabular}{|} 
\\
$\dot{2}$ \\
$\dot{8}$ \\
$\dot{8}$
\end{tabular} & $\begin{array}{l}\dot{\infty} \\
\delta \\
\delta \\
0\end{array}$ & in & $\begin{array}{l}\tilde{D} \\
\mathrm{~N} \\
\dot{\infty} \\
0 \\
0 \\
0 \\
\dot{J}\end{array}$ & 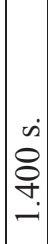 & $\begin{array}{l}\dot{0} \\
r \\
\dot{\theta} \\
\dot{0} \\
\delta\end{array}$ & 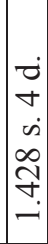 & $\begin{array}{l} \\
\dot{n} \\
0 \\
0 \\
0\end{array}$ & $\begin{array}{l}\dot{x} \\
8 \\
\stackrel{0}{0} \\
\dot{\sim}\end{array}$ & $\begin{array}{l}\dot{\infty} \\
0 \\
\infty \\
\dot{0} \\
\dot{0}\end{array}$ & $\begin{array}{l}\dot{1} \\
8 \\
8 \\
0 \\
0 \\
0\end{array}$ & $\begin{array}{l}\dot{m} \\
n \\
\\
i\end{array}$ & $\mid \begin{array}{l}\dot{n} \\
\dot{0} \\
\infty \\
\sim \\
\sim \\
\end{array}$ & $\begin{array}{c}\tilde{\sigma} \\
r \\
\dot{m} \\
b \\
\\
\dot{\nabla}\end{array}$ & $\begin{array}{c}\dot{m} \\
\dot{2} \\
\tilde{n} \\
-\end{array}$ & $\begin{array}{l}\dot{n} \\
\stackrel{8}{0} \\
\dot{\theta} \\
\dot{-}\end{array}$ & $\mid \begin{array}{c}\dot{n} \\
8 \\
8 \\
\dot{0} \\
\dot{0}\end{array}$ & $\left|\begin{array}{c}\dot{1} \\
8 \\
8 \\
\dot{0} \\
\dot{v}\end{array}\right|$ & $\underset{\dot{\infty}}{\dot{8}}$ & $\left|\begin{array}{c}\tilde{\Xi} \\
\Xi \\
\dot{0} \\
- \\
\dot{\infty} \\
\infty \\
\infty \\
\dot{J} \\
\infty\end{array}\right|$ & 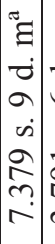 & $\begin{array}{l}\overrightarrow{0} \\
\dot{0} \\
\dot{\sigma} \\
\vec{\sigma} \\
\dot{r}\end{array}$ & $\begin{array}{l}\overrightarrow{0} \\
\infty \\
\dot{\infty} \\
0 \\
\varnothing \\
0 \\
0 \\
\dot{0} \\
0\end{array}$ & $\begin{array}{l}\dot{x} \\
\stackrel{n}{=} \\
\Xi\end{array}$ \\
\hline$\dot{m}$ & $\begin{array}{l}\dot{0} \\
0 \\
0 \\
\dot{n} \\
\hat{r}\end{array}$ & $\dot{s}$ & $\dot{n}$ & $\begin{array}{l}\dot{n} \\
\text { in }\end{array}$ & $\begin{array}{l}\dot{0} \\
m \\
\dot{m} \\
0 \\
0 \\
n \\
m\end{array}$ & $\begin{array}{l} \\
\dot{n} \\
n \\
m\end{array}$ & 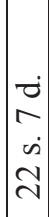 & $\begin{array}{l}\tilde{J} \\
\Xi \\
\tilde{0} \\
\infty \\
\dot{\infty} \\
\tilde{n} \\
\tilde{n}\end{array}$ & {$\left[\begin{array}{c}\widetilde{J} \\
\Xi \\
\tilde{\sigma} \\
+ \\
\dot{\infty} \\
0 \\
-\end{array}\right.$} & $\begin{array}{l}\text { zं } \\
0 \\
\dot{n} \\
\text { N } \\
\text { in }\end{array}$ & $\begin{array}{l}\dot{D} \\
m \\
\dot{m} \\
\stackrel{尺}{N}\end{array}$ & $\begin{array}{l}\dot{1} \\
i n \\
0\end{array}$ & 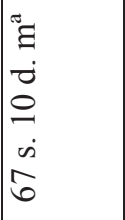 & $\begin{array}{l}\dot{0} \\
\infty \\
\dot{\infty} \\
\dot{0}\end{array}$ & $\begin{array}{c}\overrightarrow{0} \\
= \\
\dot{\omega} \\
\stackrel{0}{0}\end{array}$ & $\begin{array}{l}\dot{0} \\
\dot{\sigma} \\
\dot{n} \\
\tilde{m} \\
m\end{array}$ & $\begin{array}{l}\dot{n} \\
\stackrel{+}{+}\end{array}$ & $\begin{array}{l}\dot{n} \\
\stackrel{n}{n} \\
\end{array}$ & $\begin{array}{l}\dot{n} \\
\dot{n} \\
\dot{n}\end{array}$ & $\dot{\varphi}$ & $\begin{array}{c}\dot{d} \\
\sim \\
\dot{s} \\
0 \\
\vec{N}\end{array}$ & $\mid \begin{array}{c}0 \\
0 \\
\dot{b} \\
5 \\
\infty \\
-1\end{array}$ & $\begin{array}{l}\dot{\sigma} \\
\sigma \\
\dot{n} \\
\dot{\sigma}\end{array}$ & $\begin{array}{l}\dot{D} \\
\text { N } \\
\dot{\infty} \\
\dot{8} \\
\dot{n}\end{array}$ & $\begin{array}{l}\dot{\sigma} \\
\sim \\
\dot{n} \\
\hat{N}\end{array}$ \\
\hline 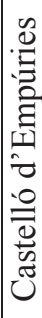 & 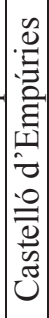 & 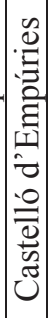 & 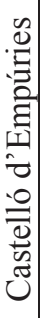 & 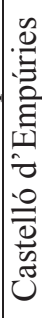 & : & 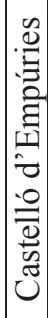 & 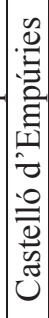 & 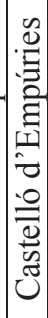 & 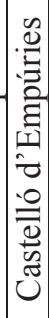 & Ũ & 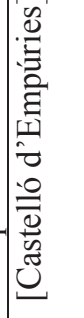 & 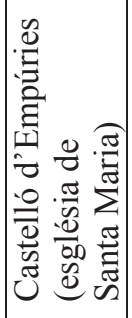 & 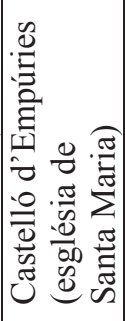 & | & 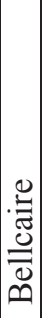 & 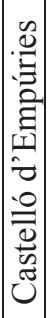 & 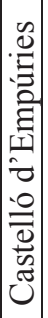 & 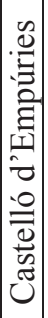 & 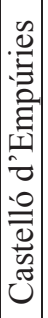 & 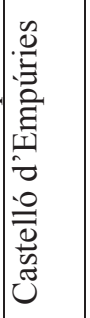 & 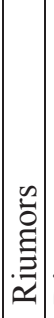 & . & 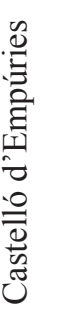 & 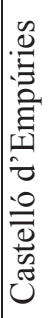 & 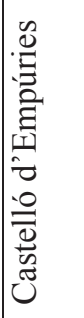 \\
\hline 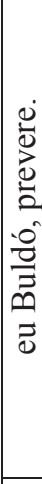 & 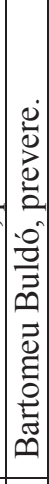 & $\begin{array}{c}\dot{2} \\
0 \\
0 \\
0 \\
0 \\
0 \\
0 \\
0 \\
0 \\
0 \\
0 \\
0 \\
0 \\
0 \\
0 \\
0 \\
0 \\
0 \\
0 \\
0 \\
\text { II }\end{array}$ & 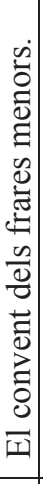 & 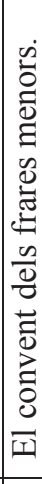 & 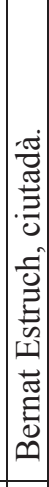 & 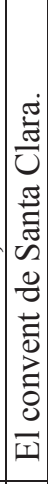 & 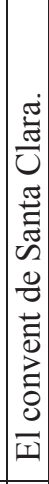 & 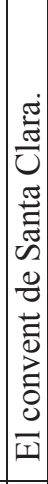 & 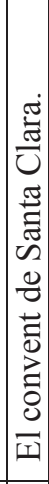 & 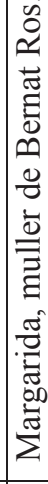 & 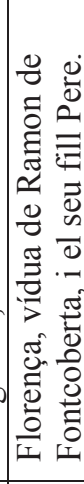 & 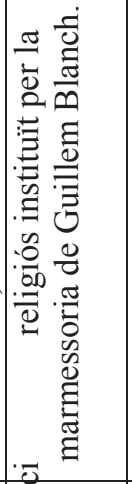 & 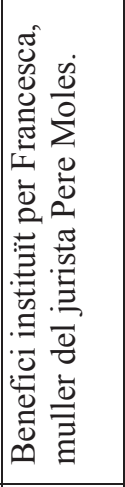 & 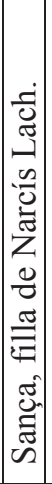 & 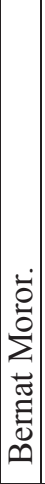 & 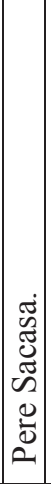 & 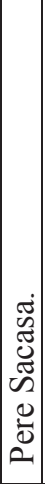 & $\mid \begin{array}{c}\frac{1}{0} \\
\mathscr{2} \\
0 \\
\oplus \\
0 \\
0 \\
0 \\
0\end{array}$ & 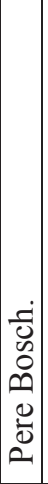 & 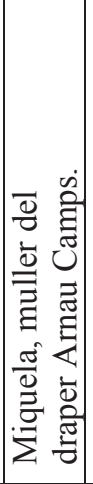 & 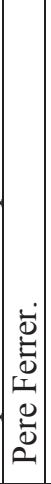 & 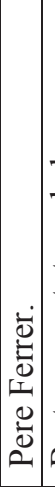 & 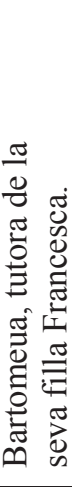 & 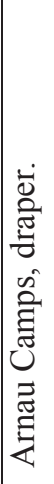 & 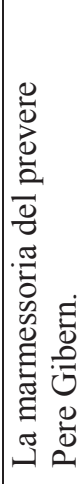 \\
\hline 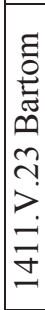 & 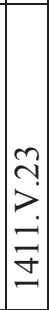 & 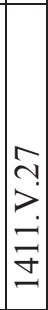 & 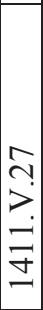 & 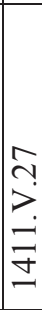 & 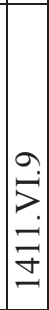 & 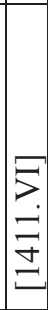 & $\begin{array}{l}\bar{z} \\
\bar{\Xi} \\
\end{array}$ & 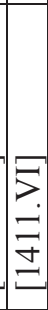 & $\begin{array}{l}\bar{z} \\
\bar{z} \\
\bar{z} \\
\end{array}$ & $\begin{array}{l}\text { 三 } \\
\bar{\Xi} \\
\end{array}$ & 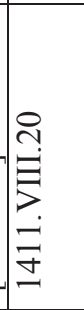 & 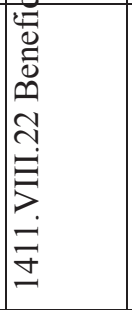 & 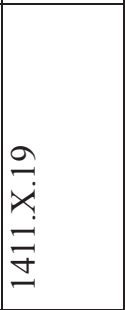 & 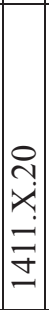 & $\mid \begin{array}{c}\vec{\sim} \\
\dot{x} \\
\vdots \\
\bar{\Xi} \\
\end{array}$ & 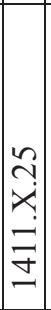 & 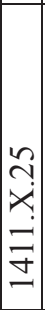 & 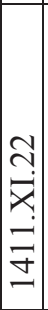 & 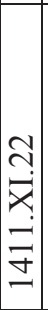 & 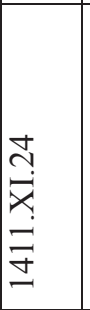 & 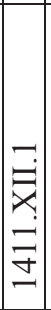 & 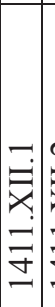 & 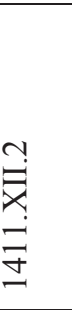 & 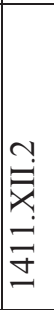 & 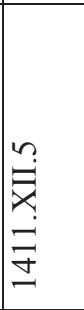 \\
\hline
\end{tabular}




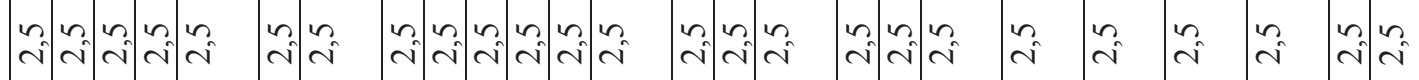

\begin{tabular}{|c|c|c|c|c|c|c|c|c|c|c|c|c|c|c|c|c|c|c|c|c|c|c|c|}
\hline $\begin{array}{c}\dot{\infty} \\
\stackrel{\sim}{\sim}\end{array}$ & 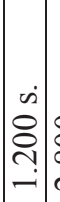 & 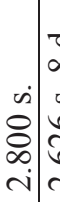 & 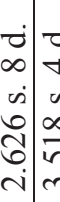 & $\begin{array}{l}\dot{0} \\
\dot{v} \\
\dot{n} \\
\infty \\
\dot{n} \\
\dot{n}\end{array}$ & $\begin{array}{c}\dot{n} \\
0 \\
0 \\
0 \\
\dot{0} \\
\stackrel{\sim}{0}\end{array}$ & $\begin{array}{c}\dot{\infty} \\
0 \\
\stackrel{n}{N} \\
\dot{0}\end{array}$ & $\begin{array}{c}\dot{0} \\
\infty \\
\dot{\infty} \\
0 \\
\dot{0} \\
\tilde{0} \\
0\end{array}$ & $\mid \begin{array}{c} \\
\\
\dot{2} \\
0 \\
\ddot{n} \\
\dot{\nu}\end{array}$ & 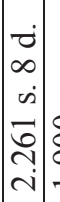 & 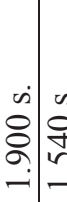 & 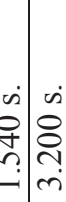 & $\mid \begin{array}{l}n \\
8 \\
8 \\
0 \\
0 \\
0\end{array}$ & $\left|\begin{array}{c}\dot{x} \\
\grave{\delta} \\
\infty \\
\dot{\sim}\end{array}\right|$ & 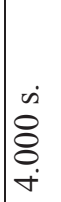 & 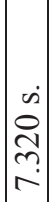 & 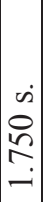 & $\begin{array}{l}\dot{n} \\
\dot{8} \\
\varnothing \\
\dot{\Xi}\end{array}$ & $\begin{array}{l}\dot{\infty} \\
\stackrel{8}{8} \\
\text { ஸ̣ } \\
+\end{array}$ & $\begin{array}{l}\dot{0} \\
\sim \\
\dot{n} \\
\hat{n} \\
\tilde{n} \\
\dot{v}\end{array}$ & $\begin{array}{l}\tilde{\sigma} \\
\dot{\sigma} \\
\dot{\infty} \\
\infty \\
\ddot{n} \\
\dot{n}\end{array}$ & 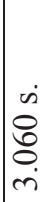 & 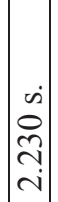 & $\begin{array}{l}\dot{\infty} \\
8 \\
8 \\
\varnothing \\
\dot{\nabla}\end{array}$ \\
\hline
\end{tabular}

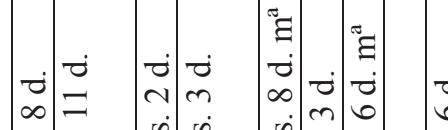

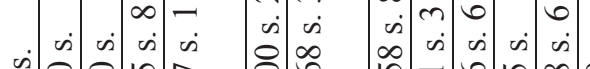

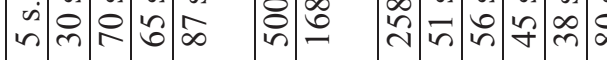

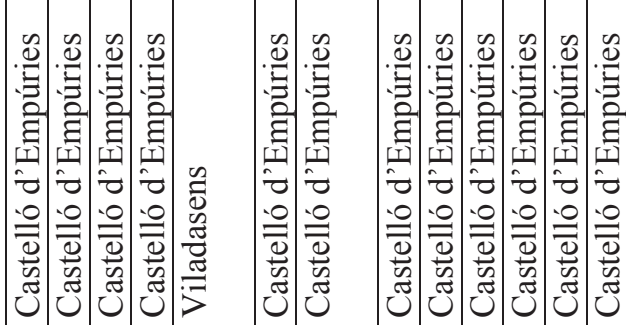

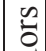

율 $\dot{\overrightarrow{0}}$

. छ

全

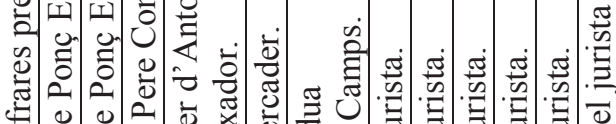

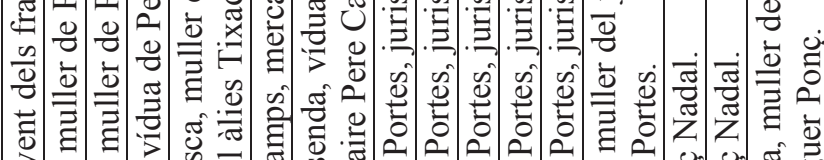

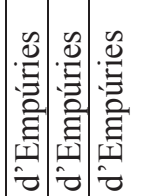

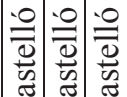

Uี

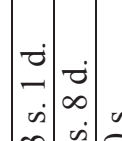

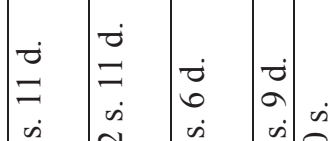

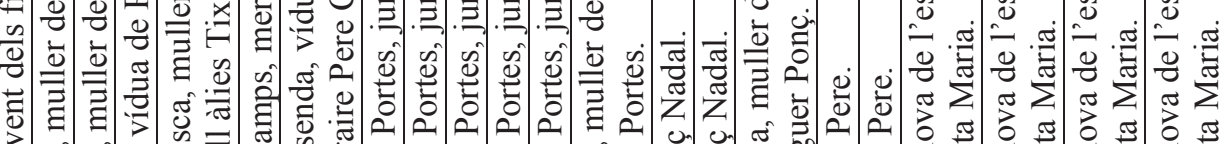

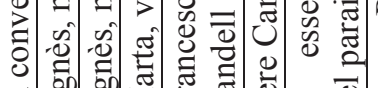

可

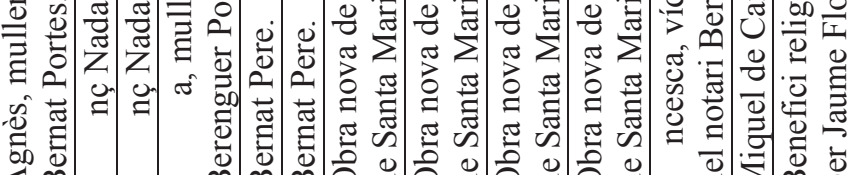

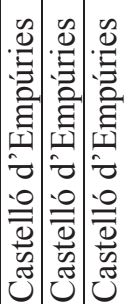

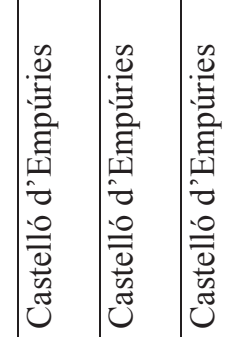

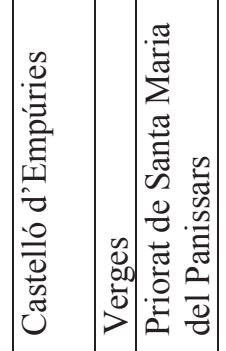

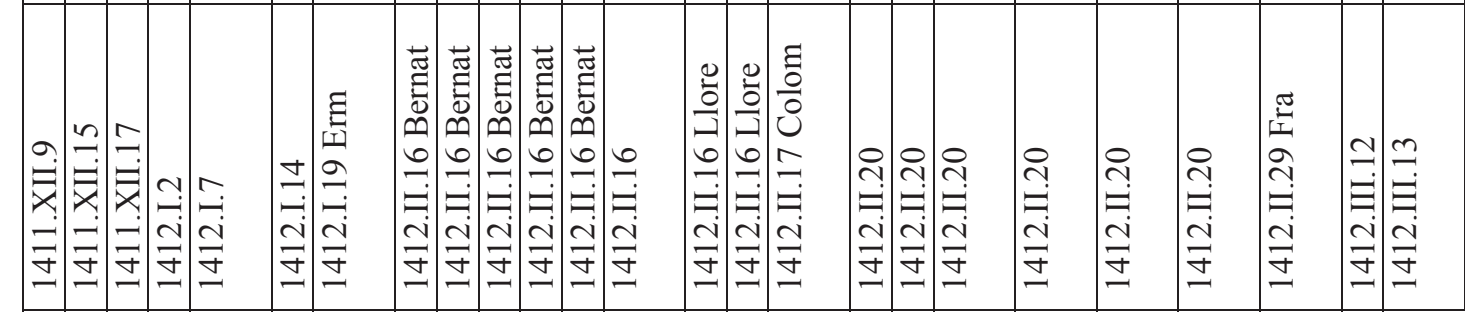




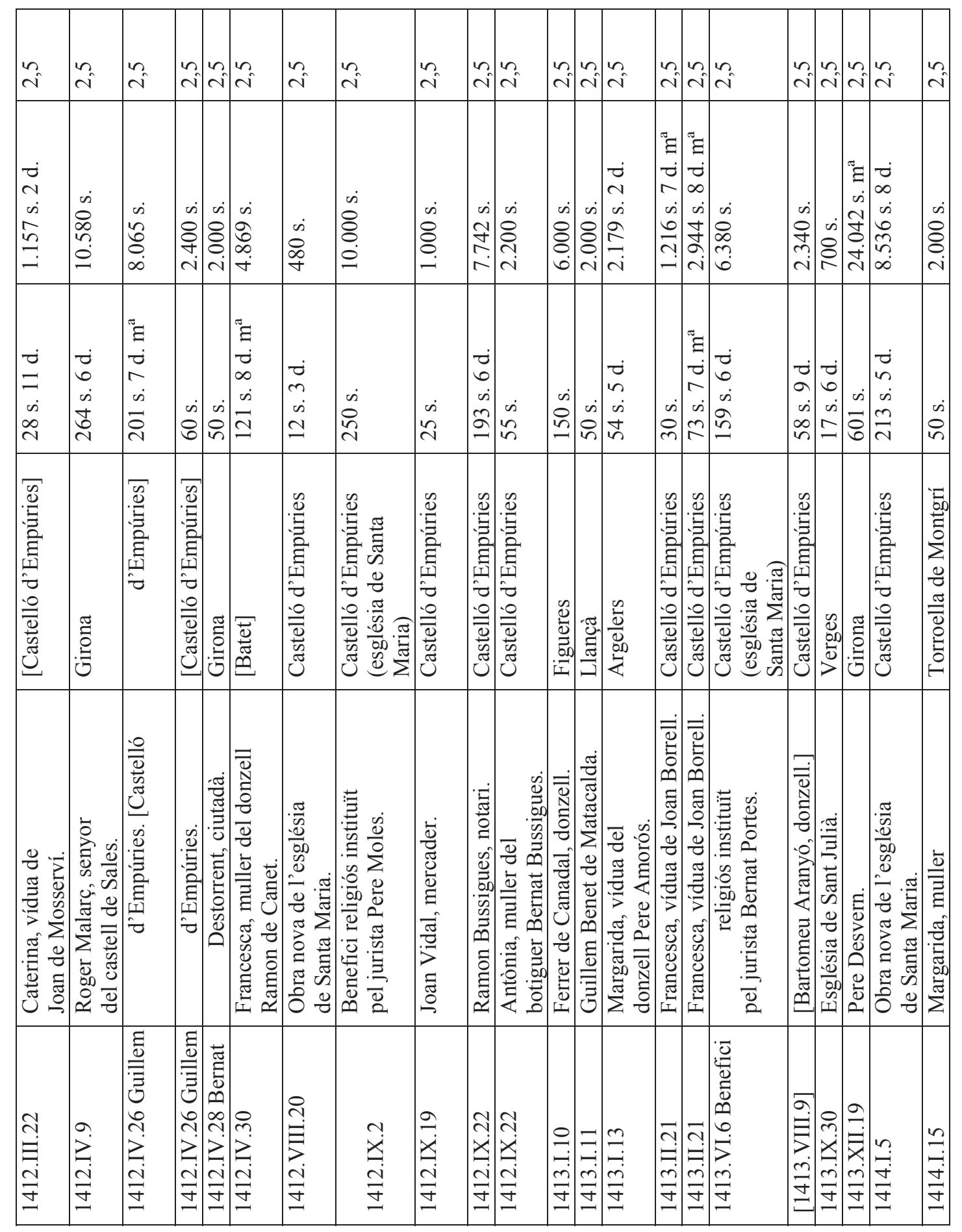




\begin{tabular}{|c|c|c|c|c|c|c|c|c|c|c|c|c|c|c|c|c|c|c|c|c|}
\hline & 'n & ñ & in & ฉ̂ & ¿n & â & ñ & in & $\stackrel{n}{\sim}$ & ฉ̂́ & ç & 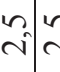 & c) & in & $\stackrel{n}{i}$ & â & ca & 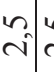 & ñ & ชn \\
\hline & $\begin{array}{l}\vec{D} \\
\infty \\
\dot{\infty} \\
\bar{\Xi} \\
0 \\
\dot{\nu}\end{array}$ & $\begin{array}{c}\dot{0} \\
\infty \\
\dot{\infty} \\
\vec{n} \\
\tilde{\sigma} \\
\dot{\sigma}\end{array}$ & 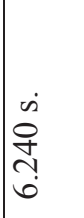 & $\begin{array}{l}\dot{m} \\
0 \\
i n \\
\\
\sim\end{array}$ & $\begin{array}{l}\dot{0} \\
\dot{\nabla} \\
\dot{m} \\
m \\
\ddot{0} \\
\dot{-}\end{array}$ & $\begin{array}{l}\dot{\infty} \\
8 \\
\varnothing \\
\dot{\sigma}\end{array}$ & $\begin{array}{l}\dot{\infty} \\
\stackrel{0}{\sigma} \\
\dot{\gamma} \\
-\end{array}$ & $\dot{m}$ & $\begin{array}{l}\dot{i} \\
\dot{\delta} \\
\stackrel{\sim}{-}\end{array}$ & 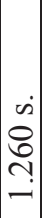 & 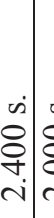 & 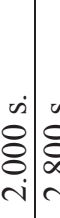 & \begin{tabular}{c|c}
$\dot{\infty}$ & \\
$\delta$ & \\
$\infty$ & \\
$\dot{\nu}$ &
\end{tabular} & $\begin{array}{l}\dot{n} \\
\wp \\
\varnothing \\
\varrho \\
\dot{0} \\
.\end{array}$ & $\begin{array}{l}\tilde{D} \\
\beth \\
\dot{m} \\
\dot{0} \\
\dot{n} \\
\tilde{n} \\
m\end{array}$ & $\begin{array}{l}\dot{1} \\
8 \\
8 \\
\dot{0} \\
\dot{0}\end{array}$ & $\begin{array}{l}\dot{1} \\
8 \\
\delta \\
\dot{0} \\
\dot{0}\end{array}$ & 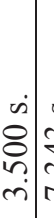 & $\begin{array}{l}\dot{m} \\
\stackrel{m}{+} \\
\stackrel{?}{r}\end{array}$ & $\begin{array}{l}\tilde{\Xi} \\
\tilde{D} \\
\dot{\sigma} \\
\dot{\infty} \\
0 \\
\stackrel{n}{n}\end{array}$ \\
\hline & $\begin{array}{l}\tilde{J} \\
\Xi \\
\dot{0} \\
m \\
\dot{n} \\
0 \\
i n\end{array}$ & 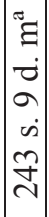 & $\begin{array}{l}\dot{\sigma} \\
a \\
\dot{m} \\
\tilde{n} \\
i n\end{array}$ & $\begin{array}{l}\overrightarrow{0} \\
a \\
\dot{\infty} \\
\infty \\
n\end{array}$ & $\begin{array}{l}\dot{\partial} \\
\dot{v} \\
\dot{n} \\
\ddot{\lambda}\end{array}$ & $\stackrel{\dot{\infty}}{8}$ & $\begin{array}{l}\dot{d} \\
n \\
\dot{n} \\
n \\
n\end{array}$ & $\begin{array}{l}\overrightarrow{0} \\
0 \\
\dot{n} \\
\end{array}$ & $\begin{array}{c}\tilde{\Xi} \\
\Xi \\
\dot{m} \\
0 \\
\tilde{n}\end{array}$ & $\begin{array}{l}\vec{\delta} \\
0 \\
\dot{0} \\
6 \\
m\end{array}$ & $\begin{array}{l}\dot{n} \\
\dot{0}\end{array}$ & $\dot{m} \dot{i n}$ & $\dot{s}$ & $\begin{array}{l}\dot{n} \\
\stackrel{0}{2} \\
\stackrel{n}{2}\end{array}$ & $\begin{array}{l}\tilde{\Xi} \\
\tilde{D} \\
0 \\
0 \\
\dot{1} \\
\dot{\infty} \\
\infty \\
\infty\end{array}$ & $\begin{array}{l}\dot{n} \\
\stackrel{0}{n}\end{array}$ & $\begin{array}{c}\dot{m} \\
\dot{n} \\
\dot{n}\end{array}$ & \begin{tabular}{c|c}
$\dot{c}$ \\
0 \\
$\dot{n}$ \\
$\hat{\infty}$ \\
$\dot{\infty}$
\end{tabular} & $\begin{array}{l}\overrightarrow{0} \\
r \\
\dot{m} \\
\hat{\infty} \\
\infty\end{array}$ & $\begin{array}{l}\stackrel{\Xi}{\Xi} \\
\dot{\sigma} \\
0 \\
\dot{\infty} \\
\infty \\
-\end{array}$ \\
\hline & 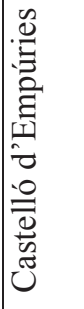 & 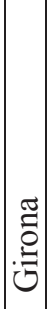 & 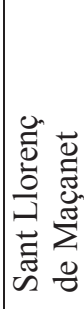 & 芫 & 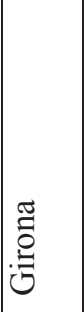 & 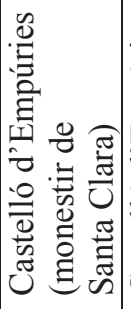 & 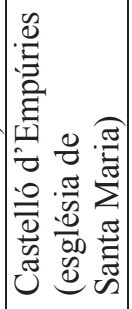 & 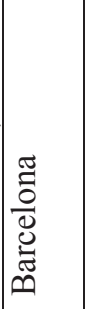 & . & 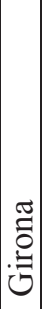 & : & 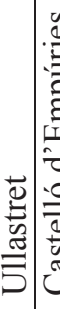 & 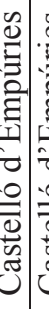 & 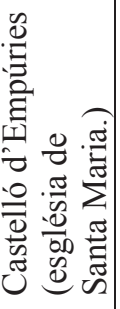 & ֻே: & 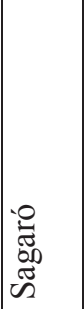 & 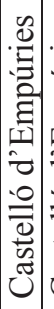 & 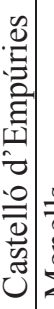 & $\begin{array}{l} \\
\infty \\
\frac{0}{0} \\
\Sigma \\
\Sigma\end{array}$ & 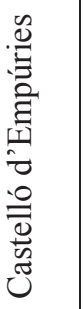 \\
\hline 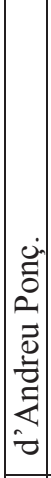 & 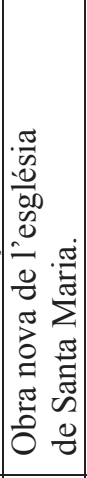 & 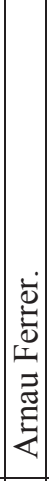 & 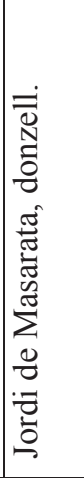 & 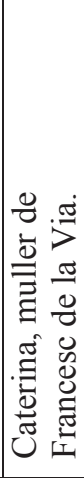 & 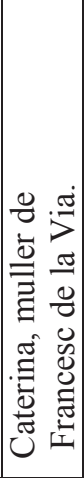 & 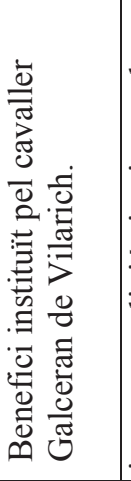 & 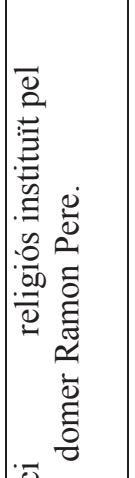 & 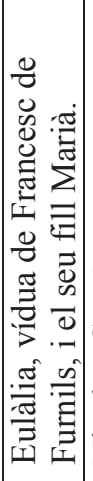 & 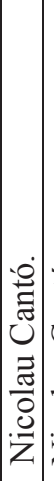 & 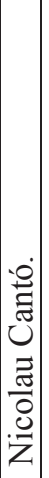 & 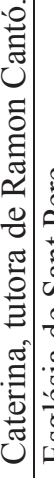 & 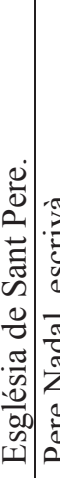 & 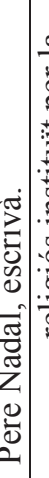 & 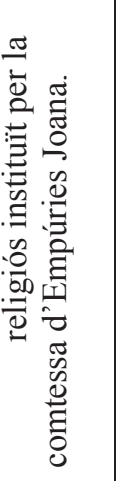 & 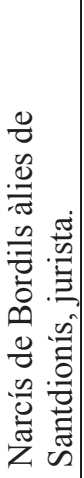 & 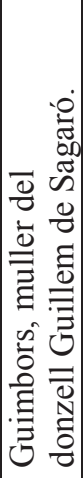 & 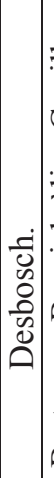 & 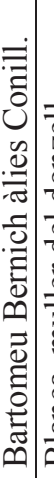 & 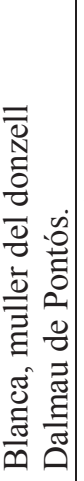 & 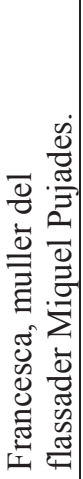 \\
\hline & 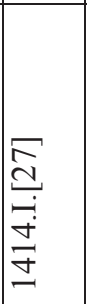 & 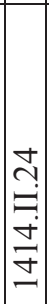 & 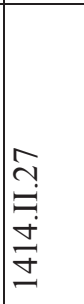 & 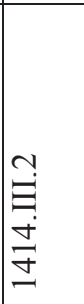 & 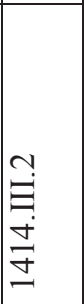 & 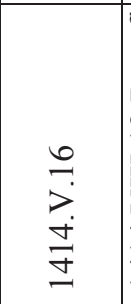 & 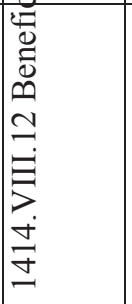 & 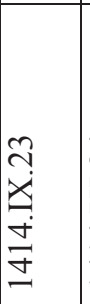 & $\begin{array}{l}\stackrel{\Xi}{\sim} \\
\dot{\bar{x}} \\
\dot{ \pm} \\
\dot{\Xi}\end{array}$ & 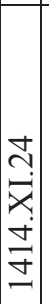 & 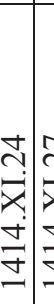 & 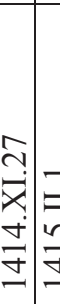 & 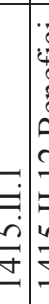 & 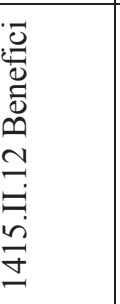 & 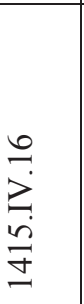 & 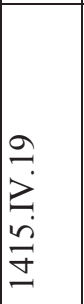 & 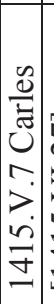 & 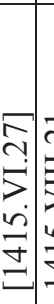 & 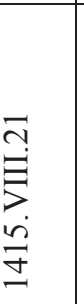 & 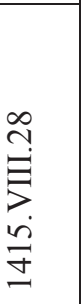 \\
\hline
\end{tabular}




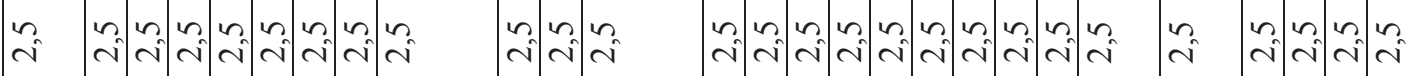

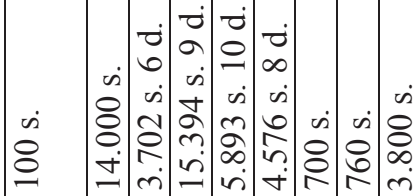

$\dot{\tau}$

$\dot{r} \dot{\dot{s}} \dot{\dot{s}}$

年

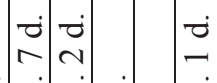

.

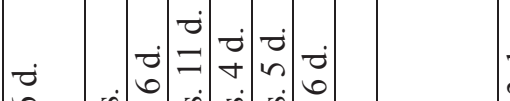

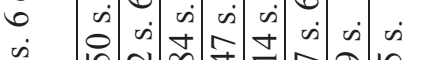

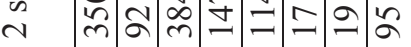

vi-

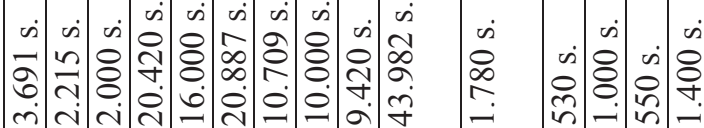

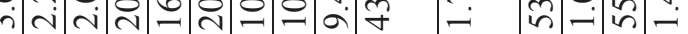

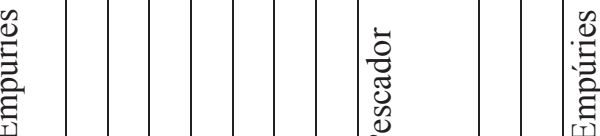

न

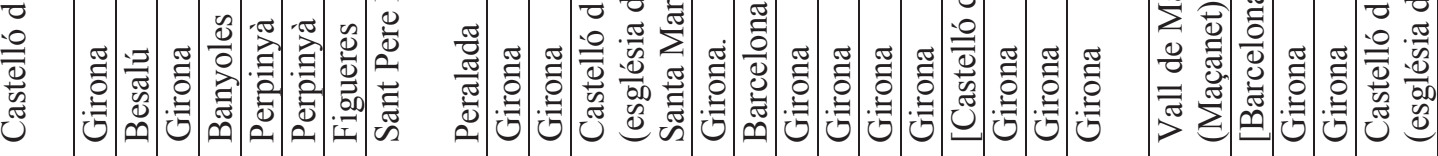

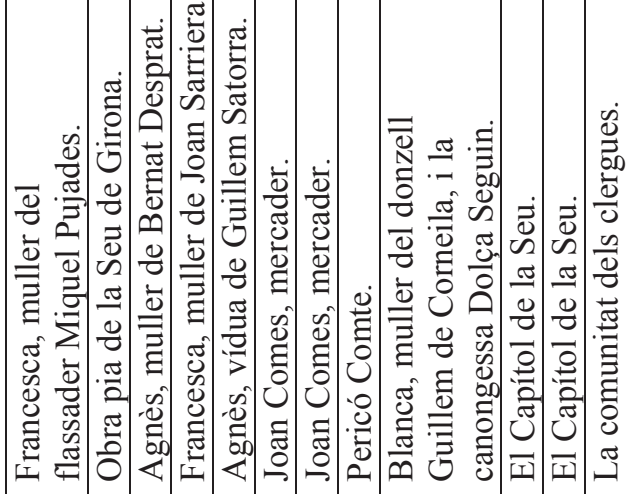

هี丶

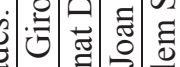

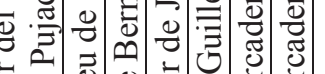

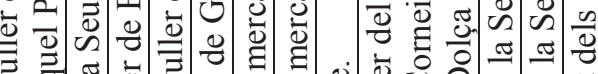

芩.

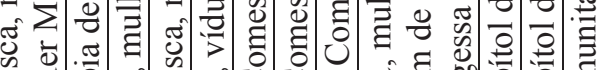

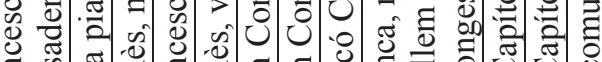

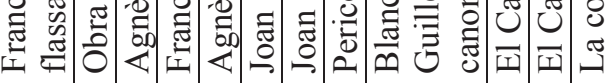

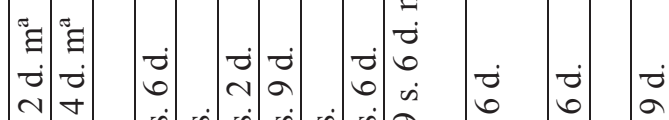

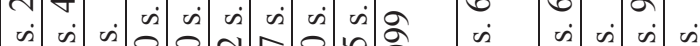

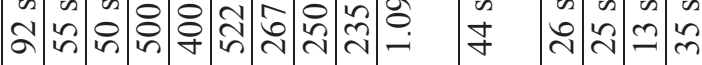




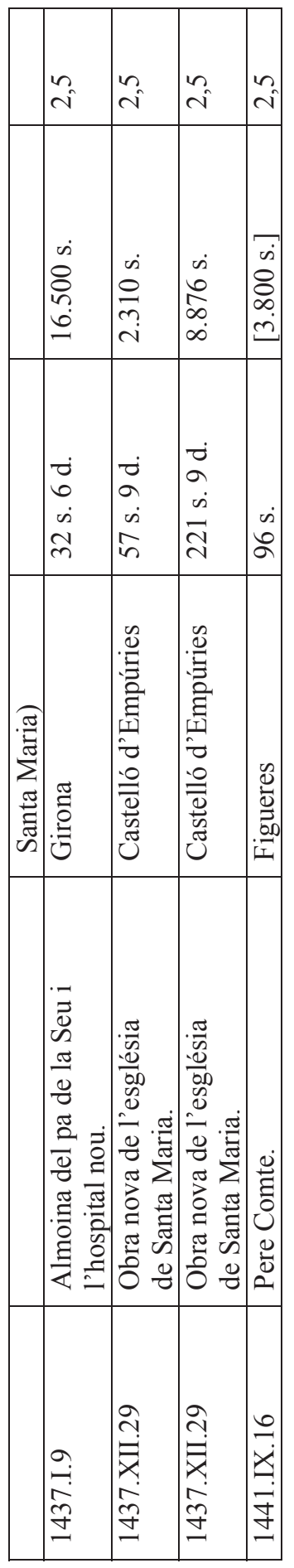


